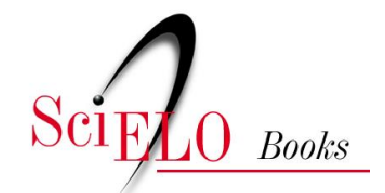

\title{
Frente de expansão e estrutura agrária
}

\author{
estudo do processo de penetração numa área da Transamazônia
}

\section{Otávio Guilherme Velho}

VELHO, OG. Frente de expansão e estrutura agrária: estudo do processo de penetração numa área da Transamazônia [online]. Rio de Janeiro: Centro Edelstein de Pesquisas Sociais, 2009, 172p. ISBN: 978-85-9966-291-5. Available from SciELO Books $<$ http://books.scielo.org $>$.

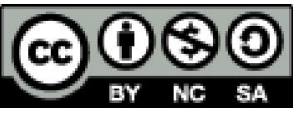

All the contents of this chapter, except where otherwise noted, is licensed under a Creative Commons Attribution-Non Commercial-ShareAlike 3.0 Unported.

Todo o conteúdo deste capítulo, exceto quando houver ressalva, é publicado sob a licença Creative Commons Atribuição Uso Não Comercial - Partilha nos Mesmos Termos 3.0 Não adaptada.

Todo el contenido de este capítulo, excepto donde se indique lo contrario, está bajo licencia de la licencia Creative Commons Reconocimento-NoComercial-CompartirIgual 3.0 Unported. 


\section{BIBLIOTECA VIRTUAL DE CIÊNCIAS HUMANAS}

\section{FRENTES DE EXPANSÃO E ESTRUTURA AGRÁRIA}

\section{Otávio Guilherme Velho}


Otávio Guilherme Velho

\section{Frentes de expansão e} estrutura agrária

estudo do processo de penetração

numa área da Transamazônica 
Esta publicação é parte da Biblioteca Virtual de Ciências Humanas do Centro Edelstein de Pesquisas Sociais - www.bvce.org

Copyright (c) 2009, Otávio Guilherme Velho

Copyright (c) 2009 desta edição on-line: Centro Edelstein de Pesquisas Sociais Ano da última edição: 1981

Nenhuma parte desta publicação pode ser reproduzida ou transmitida por qualquer meio de comunicação para uso comercial sem a permissão escrita dos proprietários dos direitos autorais. A publicação ou partes dela podem ser reproduzidas para propósito não-comercial na medida em que a origem da publicação, assim como seus autores, seja reconhecida.

ISBN 978-85-99662-91-5

Centro Edelstein de Pesquisas Sociais

www.centroedelstein.org.br

Rua Visconde de Pirajá, 330/1205

Ipanema - Rio de Janeiro - RJ

CEP: 22410-000. Brasil

Contato: bvce@centroedelstein.org.br 
Sumário:

Prefácio à Segunda Edição

Prefácio

\section{Introdução}

Caracterização das Frentes de Expansão 6

Delimitação de Área e Tema de Estudo............................................................

\section{Os Primórdios}

\section{A Frente Pastoril}

A Frente Pecuarista no Maranhão e no Tocantins

O Burgo do Itacaiúnas

\section{A Extração Livre}

O Ciclo da Borracha

A Fase da Extração da Borracha no Médio Tocantins 32

Marabá

A Frente Extrativista da Castanha

A Primeira Fase da Frente Extrativista da Castanha 48

\section{Marabá da Castanha e do Diamante}

A Atividade Intersticial da Agropecuária

A Frente Mineradora

\section{Boi e Castanha}

A Terceira Fase da frente Extrativista da Castanha.

\section{A Frente Agrícola}

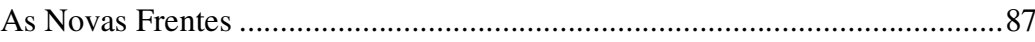

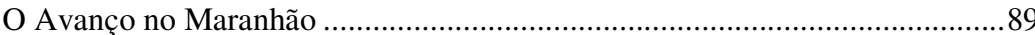

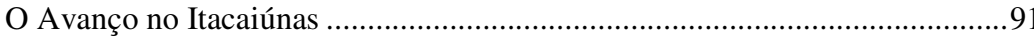

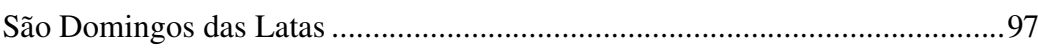

As Novas Transformações Supra Locais e os seus Reflexos ...........................111

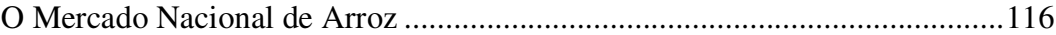

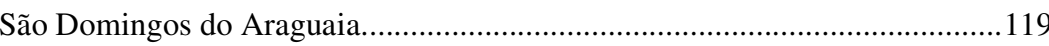

O Ramal e a Nova Exploração Mineral.............................................................130

\section{A Transamazônica}

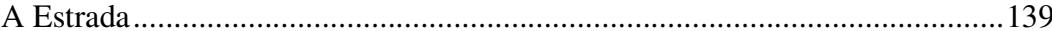

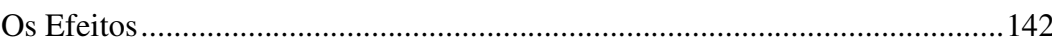

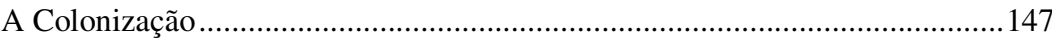

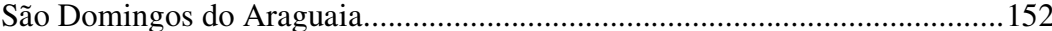

9. Conclus̃̃es ...................................................................................... 154

Bibliografia ............................................................................................. 164 


\section{PREFÁCIO À SEGUNDA EDIÇÃO}

Este livro já se encontrava esgotado há alguns anos. Eu mesmo, como autor, tinha dúvidas sobre a reedição, devido a sua relativa desatualização, tanto em termos de informações, quanto das minhas próprias reflexões sobre os assuntos tratados.

A decisão de republicá-lo oito anos após a primeira edição deveu-se a considerações relacionadas à crescente atualidade do tema e à crescente importância da própria região onde se deu o estudo.

Efetivamente, o pequeno produtor rural parece finalmente ir ganhando certa legitimidade entre nós. Na época em que foi escrito o livro, em pleno auge do milagre e da repressão, tal não acontecia. $\mathrm{O}$ leitor perceberá como, sobretudo nos últimos capítulos, está implícita uma espécie de "defesa" do pequeno produtor numa conjuntura que lhe era particularmente desfavorável ${ }^{1}$, a ponto de no âmbito da própria esquerda não ser em geral possuidor de muito crédito.

Hoje as coisas parecem, pelo menos em parte, ir mudando.

E o posseiro na Amazônia chega a ser (exageradamente) exaltado como a ponta de lança daquilo que eu chamava no último capítulo (jogando com o jargão da época) de arcaico modernizado.

As minhas experiências posteriores com grupos de pequenos produtores no Pará e no Maranhão, por outro lado, me mostraram o quanto havia de recorrente na organização social desses grupos, inclusive nas diferenças - tanto as internas aos grupos, quanto as contidas nas oposições entre grupos que eu havia sintetizado na dicotomia centro-beira. É de fato com um sentimento de espanto que me vejo constantemente voltando a este primeiro trabalho e comparando-o com novas experiências, mesmo quando isso significa rever impressões da época. Nesse sentido, creio que a sua atualidade é garantida num outro nível que não o das informações conjunturais.

1 Apesar dos grandiosos planos de colonização da Amazônia que supostamente O beneficiariam, e de que o penúltimo capítulo deste livro constituiu uma das primeiras críticas a Contrariar o avassalador clima de ufanismo então montado, em geral paralisante para as próprias oposições.
Quanto à região, propriamente, é até curioso para mim relembrar o espanto dos amigos (aí incluído o do próprio editor Jorge Zahar) ao saberem, já desde 1966, da insólita escolha por trabalhar em local que em geral se tinha dificuldade até em localizar no mapa. E que não parecia ter a menor relevância do ponto de vista das "grandes questões". Na mesma ocasião, porém, em que o livro vinha a público (1972), começavam a chegar as primeiras e fragmentárias notícias que notabilizariam não só a região, mas o próprio povoado de São Domingos do Araguaia, transformando muitos dos personagens anônimos deste livro em protagonistas de uma verdadeira guerra. Que a região, pelos mesmos ou por outros motivos, manteve-se bem viva, inclusive nas preocupações governamentais, é atestado pela criação recente de um grupo executivo de terras do Araguaia-Tocantins.

Um motivo adicional de interesse para mim na reedição do livro está na convicção de que, apesar de todas as minhas andanças e mudanças, encontram-se aqui presentes elementos que continuo acreditando serem importantes para uma discussão política a que permaneço ligado ${ }^{2}$. E em caráter ainda mais pessoal e ao mesmo tempo mais amplo, porque não só político, é reconfortador saber que "eu” já estava presente neste livro. Nesse sentido, personalizo inteiramente a observação final que fazia sobre o povoado camponês e constato que no meio de tanta mudança. "... e num momento tão crucial, é curioso verificar, nesse nosso último lance de olhos sobre São Domingos do Araguaia, a permanência” (p. 160).

Abstive-me, evidentemente, de quaisquer alterações no texto, que a meu ver o tornariam inautêntico (inclusive prejudicando uma análise dos debates correntes na época e de suas limitações) e confundiriam desnecessariamente os especialistas que já o vêm utilizando.

É bem provável que esta seja não só a segunda, mas também a última edição deste livro. Ao mesmo tempo em que considero oportuna a sua reedição agora, creio que o que tem de melhor vai sendo absorvido em

${ }^{2}$ Evidentemente, desde então escrevi vários outros textos ligados a essa discussão. Para orientação do leitor pode-se mencionar, por seu caráter abrangente, Capitalismo Autoritário e Campesinato (DIFEL, $2^{\mathrm{a}}$ ed., 1979) e, por ser o mais recente, "A Propósito de Terra e Igreja”, em Encontros com a Civilização Brasileira, n. 23. 
outros trabalhos, meus e de outros. Creio também que não pode ser outro o desejo de um autor.

O.G.V.

Rio, 10 de março de 1980

\section{PREFÁCIO}

O corpo principal deste trabalho foi apresentado em junho de 1970 como dissertação de mestrado ao Programa de Pós-Graduação em Antropologia Social do Departamento de Antropologia, do Museu Nacional da Universidade Federal do Rio de Janeiro.

Uma viagem posterior à região onde se deu o estudo, bem como a Belém e São Luís, permitiu a verificação e complementação de certos dados, e sobretudo uma impressão das novas transformações ocorridas, particularmente com a construção da rodovia Transamazônica.

Como um todo, portanto, o estudo resulta, no que diz respeito ao seu suporte em trabalho de campo, de quatro viagens realizadas ao Brasil Central e à Amazônia Oriental em dezembro de 1966, janeiro-fevereiro de 1969, outubro-novembro de 1969 e em novembro de 1971-janeiro de 1972.

Julguei preferível não modificar a forma geral de apresentação do corpo principal do trabalho, apesar, de ter incluído diversas alterações e complementações de dados. Assim, o leitor poderá apreciar a história da região e das diversas frentes de expansão que a atravessaram, apresentada sem nenhum preconceito teleológico advindo do prévio conhecimento da rodovia Transamazônica, cuja construção foi anunciada às vésperas da conclusão da dissertação de mestrado.

Em um capítulo inteiramente novo (A Transamazônica), exponho minhas impressões sobre os desenvolvimentos mais recentes, apoiado no conhecimento anterior apresentado nos demais capítulos. Com isto creio evitar o erro metodológico e teórico de realizar uma apreciação sobre mudança estribado na conjetura de um zero absoluto de história anterior a um fake-off arbitrário, que no caso seria a construção da estrada.

No último capítulo apresento as conclusões do estudo, procurando desdobrá-las a partir das novas ocorrências e de novos conhecimentos sobre situações camponesas e de fronteira.

$\mathrm{Na}$ impossibilidade de agradecer a todas as pessoas e instituições que durante estes seis anos contribuíram de alguma maneira nas diversas etapas de elaboração do trabalho, prefiro formular um agradecimento geral, com alguns destaques. 
$\mathrm{O}$ primeiro destes não poderia deixar de se referir aos professores e colegas do Programa de Pós-Graduação em Antropologia Social do Museu Nacional, a quem agradeço nas pessoas do Dr. Roberto Augusto da Matta, do Dr. David Maybury-Lewis e, sobretudo, do Dr. Roberto Cardoso de Oliveira, co-diretor do Programa e meu orientador de dissertação. Foi Roberto Cardoso de Oliveira quem despertou pela primeira vez o interesse pelo estudo sistemático das frentes de expansão da sociedade brasileira e forneceu, a partir das questões de fricção interétnica, a referência inicial para o trabalho (ver CARDOSO DE OLIVEIRA, 1962, 1964, 1966, 1967, 1968, 1972; LARAIA.E MATTA; MELATTI; VELHO, 1967). Em todos os momentos do meu próprio estudo recebi dele um seguro estímulo intelectual e um exemplo de grande dedicação profissional. Desde 1966 trabalhei sob a sua orientação no Projeto "Estudo do 'Colonialismo Interno' no Brasil" de sua responsabilidade e patrocinado pelo Conselho Nacional de Pesquisas. O seu apoio nestes seis anos tem ido muito além dos seus deveres profissionais, demonstrando, seguidamente, provas de grande generosidade. A ele o meu agradecimento, sincero.

Não poderia deixar de mencionar, ainda, um agradecimento ao Professor Roque de Barros Laraia, com quem estive pela primeira vez na região de estudo, e que pelo seu exemplo de equilíbrio e eficiência profissional marcou profundamente a minha iniciação ao trabalho de campo antropológico.

Nas diversas etapas do trabalho recebi apoio sob diversas formas do Conselho Nacional de Pesquisas, do Conselho de Pesquisas da Universidade Federal do Rio de Janeiro, do Centro Latino-Americano de Pesquisas em Ciências Sociais e sobretudo do Departamento, de Antropologia do Museu Nacional e da Fundação Ford. A essas entidades registro os meus agradecimentos.

Por fim, resta expressar a minha gratidão a todos os que na região onde realizei o meu estudo - e particularmente na cidade de Marabá e em São Domingos do Araguaia - me acolheram com extrema simpatia, paciência, sensibilidade e seguidamente com grande consciência de sua própria história e de sua situação.

O. G. V.

Rio de Janeiro, abril de 1972

\section{INTRODUÇÃO}

Os limites geográficos do Brasil de hoje foram estabelecidos graças aos movimentos de expansão que se deram a partir do século XVI do litoral do Atlântico em direção ao interior do continente sul-americano. Desde os tratados de limites celebrados ainda na época colonial, até os negociados pelo Barão do Rio Branco no início deste século, o argumento fundamental utilizado por nossa diplomacia foi o da posse de fato que teria sido assegurada por nossas fronteiras em movimento. Na realidade, todavia, em face do gênero de colonização de que o Brasil foi objeto, em muitos casos a posse não foi absolutamente definitiva, reduzindo-se, em casos extremos, a meras incursões ou expedições exploratórias. Ligada em geral a ciclos coloniais de economia, estava a posse, nos casos em que de alguma forma se deu, sujeita a fatores historicamente incontroláveis, tais como o esgotamento, de reservas minerais ou do solo, e oscilações de preços no mercado internacional em virtude da concorrência de outros produtores ou do aparecimento de bens substitutivos. E uma vez encerrado um ciclo, aquelas áreas que não conseguiam readaptar-se a um novo ciclo econômico voltavam a uma situação de maior ou menor marginalização.

Se acrescentarmos o fato de que vastas áreas compreendidas dentro de nossas fronteiras políticas, devido à inexistência prática de atrativos econômicos de qualquer espécie, foram contornadas na época da fixação das fronteiras, entenderemos a existência em nossos dias de áreas ainda sujeitas a frentes de expansão da sociedade brasileira.

\section{Caracterização das Frentes de Expansão}

Manipulando, com certo grau de arbitrariedade, alguns dados dos Censos de 1950 e 1960, especialmente o incremento demográfico ocorrido na década de 50, poderíamos tentar definir, de acordo com a divisão adotada pelo IBGE na época, as zonas fisiográficas que estariam sujeitas à ação de frentes de expansão nesse período, sabendo-se que o incremento demográfico não explica a ocorrência de uma frente de expansão, mas denuncia a sua existência ${ }^{1}$.

${ }^{1}$ Mesmo aceitando a distinção que faz NEIVA entre fronteira demográfica e fronteira econômica, certamente útil para os estudos de marginalidade, é certo que um avanço 
Assim, tivemos que nessa década as seguintes zonas fisiográficas experimentaram um incremento demográfico de mais de $60 \%$ :

Rondônia: Alto Madeira (todo o atual Território) Roraima: Catrimâni

Pará: Itacaiúnas e Planalto Amapá: Amapá-Macapá

Maranhão: Baixo Mearim, Pindaré e Tocantins Bahia: Extremo Sul

Espírito Santo: Norte, Baixo Rio Doce e Vitória

Rio de Janeiro: Baixada da Guanabara e Baixada do

Rio Guandu

São Paulo: São Paulo, Pereira Barreto e Andradina Paraná: Curitiba, Oeste e Norte Santa Catarina: Oeste

Mato Grosso: Aripuanã, Chapada, Poxoréu, Campo Grande, Rio Pardo e Encosta Norte

Goiás: Araguaia - Tocantins, Alto Tocantins, Rio Verde e Mato Grosso de Goiás

Diversas dessas zonas fisiográficas, mesmo em 1960, possuíam uma densidade demográfica muito baixa, o que distorce o significado do incremento demográfico. Isso torna necessária, a fim de efetivamente se saber se essas zonas estavam sujeitas à ação de frentes, a continuação da sua observação em momentos seguintes. O alto incremento demográfico nesses casos constitui apenas o indício de uma tendência possível, dado um mínimo de condições para o prosseguimento de sua ocupação. Arbitrando uma exigência mínima de 0,1 hab. $/ \mathrm{km}^{2}$ para 1960 , a fim de se ter uma certa segurança quanto à natureza do fenômeno, ficariam excluídas provisoriamente da relação a zona do Catrimâni (Roraima) e a de Aripuanã (Mato Grosso).

Por fim, como neste mesmo período experimentamos um alto índice, de urbanização, que também se manifesta em termos de incremento demo gráfico, podemos supor que as zonas de alto índice de população urbana podem ter tido boa parte de seu incremento demográfico em função desse fenômeno. Todavia, como os dois fenômenos podem não só ter a mesma origem como coexistir, e, mesmo, estimular-se mutuamente, somente retiramos da relação às zonas fisiográficas de população urbana superior a $70 \%$ do total: Vitória (Espírito Santo), Baixada da Guanabara (Rio de Janeiro), São Paulo (São Paulo), Curitiba (Paraná).

populacional em massa é em geral, nas condições brasileiras, indicativo de uma fronteira que é também econômica.
Obviamente, a arbitrariedade dos cortes, a grande extensão das zonas fisiográficas, a inexistência de distinções qualitativas e o caráter seguidamente fluido e enganador do fenômeno das frentes tomam essa relação apenas uma primeira aproximação do fenômeno que nos interessa. Todavia, já nos permite algumas considerações. Uma delas diz respeito à própria descontinuidade geográfica e variedade de situações em que se podem encontrar as frentes; já por si indicativa da necessidade de estudo de campo que permitam uma concretização maior que se revele por trás das categorias gerais, e que possam eventualmente vir mesmo a modificá-las. Nossa tendência inicial foi, em face da história, do interesse dos antropólogos pelas frentes de expansão, de defini-las preliminar e operacionalmente como sendo constituídas dos segmentos extremos das cidades brasileira que se internavam em áreas antes não exploradas, e apenas ocupadas por sociedades indígenas. Todavia, o processo histórico brasileiro, tal como o esboçamos acima, implica não só um limite mais ou menos definido da ocupação em cada momento, mas também a existência de áreas que se mantiveram até recentemente marginalizadas dentro de regiões de colonização antiga (como o Extremo Sul da Bahia), ou de outras, que após uma decadência cíclica voltam a ser objeto de interesse da reocupação num outro momento (como possivelmente é o caso do Baixo Rio do no Espírito Santo). Temos tido também alguns casos de áreas que, especialmente nos últimos tempos, graças a determinadas condições, conseguem assegurar em grau maior ou menor a manutenção do seu crescimento. Em certos casos excepcionais, áreas como estas continuam, durante um período relativamente longo, a absorver grandes contingentes populacionais. É para esses casos, aparentemente, em suas manifestações mais típicas, que WAIBEL reservou a expressão frentes pioneiras, de que um exemplo talvez tenha sido o Norte e o Oeste do Paraná.

Interessante observar que as frentes de expansão constituem, em matéria de migração, uma alternativa à urbanização. Todavia, como já assinalamos, os dois fenômenos podem coexistir numa mesma área, e mesmo se completar (como, aparentemente, ocorre na Baixada do Rio Guandu no Rio de Janeiro). Numa tipologia das frentes de expansão, a distinção entre a coexistência próxima ou não dos dois fenômenos poderia constituir um procedimento válido. A este poderíamos acrescentar um outro, que distinguisse as áreas efetivamente limites da expansão da 
sociedade brasileira, as áreas anteriormente contornadas e as áreas em processo de reocupação.

Como essas distinções, no entanto, são feitas em termos ideais, não é raro encontrar-se na realidade empírica casos em que as possibilidades se mesclam, e que por isso mesmo apresentam uma riqueza de situações que as tornam particularmente atraentes para uma descrição analítica que pretenda oferecer uma contribuição ao entendimento da dinâmica das frentes de expansão, bem como de seu papel no interior do sistema global a que pertencem.

Tal é o caso de que vamos nos ocupar, em que temos como pólo inicial de referência a cidade de Marabá.

\section{Delimitação de Área e Tema de Estudo}

Mesmo aceitando como inevitável um certo grau de arbitrariedade nos cortes realizados, à medida que dependerão dos critérios aplicados e do grau de abstração, trata-se de tarefa em geral complexa qualquer esforço de delimitação de áreas. No caso em foco, isto se torna particularmente difícil, uma vez que uma análise histórica e mesmo contemporânea parece mostrar ser quase uma característica permanente da área de que nos ocupamos estar sujeita à influência de pólos e frentes de expansão diversos, e cuja força de absorção tem variado. Afinal, trata-se quase de um verdadeiro ponto de contato entre Amazônia, Nordeste e Brasil Central, o que, aliás, constitui um de seus motivos de interesse. Segundo o IBGE: "A área de Marabá é local de encontro de povoamentos oriundos do Pará, de Goiás e do Maranhão" (IBGE, 1967, 1 vol.).

Acrescente-se a isto que o poder polarizador da própria área, seja em termos da extensão de sua influência, seja em termos da criação de características individualízadoras, também não tem sido de modo algum constante.

Todavia, a nossa preocupação central neste trabalho não é propriamente a de um estudo de área, mas prende-se ao tema das frentes de expansão; particularmente ao inter-relacionamento entre frentes diversas e ao estudo da frente de expansão agropecuária que hoje alcança a Amazônia Oriental brasileira. Nesse sentido, este estudo é apresentado sob uma 'forma de história, em que se distinguem períodos representados pela atuação de determinadas frentes de expansão. Essas frentes de expansão, por sua vez, serão caracterizadas e distinguidas de acordo, basicamente, com as relações fundamentais que estabeleçam com a natureza, e conforme as relações de produção e trabalho prevalecentes. Assim, não tomamos como primeiro passo a fragmentação da realidade maior da qual partem as forças que transformadas irão se manifestar localmente. A área, enquanto locus de estudo, servirá para nós como referência, subordinada à preocupação temática. Nesse sentido, apenas, nossa referência espacial mais estrita e permanente corresponde grosso modo ao que a FIBGE denomina hoje de microrregião de Marabá, constituída dos municípios paraenses de Tucuruí, Itupiranga, Jacundá, Marabá e São João do Araguaia ${ }^{2}$.

Dada a relevância dos assuntos tratados, bem como o interesse que a área, enquanto tal, apresenta atualmente, é de se imaginar que este estudo se preste a leituras de vários tipos. É importante frisar que a forma histórica de apresentação escolhida não implica supor-se a prior; um alto grau de continuidade histórica de tipo evolucionista. Pelo contrário, pretende-se que facilite o exame mais detalhado das relações, de continuidade versus descontinuidade. Particularmente, à medida que um desenvolvimento desigual e combinado em escala nacional e internacional relaciona, num caso concreto, uma espécie de sobre descontinuidade gerada por uma dominância de fora com as vicissitudes da acumulação local. Enquanto descrição analítica, espera-se que este estudo possa trazer uma contribuição a futuras elaborações teóricas a esse respeito.
${ }^{2}$ Os dados anteriores a 1970 serão por vezes apresentados obedecendo à antiga divisão do
IBGE, onde a zona fisiográfica do Itacaiúnas referia-se à mesma área menos o município de Tucuruí 


\section{OS PRIMÓRDIOS}

As próprias características do avanço dos colonizadores no Norte brasileiro retardaram a exploração e povoamento do Tocantins no seu curso médio, já que por muito tempo não se colocou como fator relevante a ligação sistemática com o Sul, para a qual o Tocantins mostrar-se-ia fundamental. Mesmo porque os portugueses demoraram a interessar-se pelo Norte brasileiro como um todo. Durante todo o primeiro século após a descoberta, praticamente não há iniciativas de vulto. As expedições iniciais são de molde a desencorajá-las, dado o insucesso de que se revestiram e as dificuldades por que passaram. No que diz respeito aos espanhóis, a viagem de Orellana pelo Amazonas não deixa marcas.

Enquanto isso, franceses, ingleses e holandeses realizavam as suas primdras explorações na região. Os franceses, aparentemente, por lá já haviam estado desde 1524. É, porém, a partir de 1594 que de fato tomam pé na região, com a fundação de uma colônia no Maranhão.

Tendo como ponto de partida essa colônia, os franceses saem à exploração da terra. Várias expedições são mandadas ao Pará, e Charles Des Vaux estabelece uma feitoria na foz do Tocantins. Em 1610, La Blanjartier penetra no Tocantins e explora-o pelo menos até a cachoeira de Itaboca, a qual se constituirá na história da área nos séculos seguintes no grande obstáculo e divisor entre o curso inferior do Tocantins, facilmente navegável, e o seu curso médio.

Em 1613, Daniel de La Touche penetra novamente no Tocantins, e alcança a confluência com o Araguaia, onde a expedição se subdividiu, subindo uma parte pelo Tocantins e outra pelo Araguaia. La Planque, companheiro de La Touche, permanece três anos na área.

Enquanto isso, ingleses e holandeses iam também se infiltrando na Amazônia. No entanto, aparentemente não se preocupavam com o Tocantins, ao contrário dos franceses, cujo interesse parece indicar buscarem os mesmos estabelecer uma ligação interior entre o Pará e a sua colônia no Maranhão. Capistrano de ABREU (ABREU, p. 196) informa que os ingleses preferiam a foz do Amazonas, ao passo que os holandeses teriam avançado até o Xingu. Registram-se também incursões realizadas por irlandeses.
Todavia, os portugueses por esta época, assustados com essa ação crescente e a ameaça a sua florescente economia açucareira em expansão no Nordeste, haviam iniciado a sua "marcha para o Amazonas". O domínio espanhol, a partir de 1580, permitiu que diminuíssem as preocupações com a fronteira sulina, e que para lá se voltassem.

O avanço foi lento. Tendo iniciado a conquista da Paraíba em 1583, só em 1615 tomam o Maranhão aos franceses; e, prosseguindo, fundam próximo ao delta do Amazonas uma fortaleza, origem da cidade de Belém.

A partir dai dá-se a gradativa expulsão dos concorrentes na Amazônia. Concomitantemente, inicia-se uma fase de explorações, onde avulta a viagem de Pedro Teixeira pelo Amazonas em 1637-39. Para isto concorreram inicialmente as narrativas sobre a existência de ouro trazidas pelos navegadores espanhóis que desceram o rio no século XVI.

Em 1621 cria-se o Estado do Maranhão, que ia do Ceará ao Pará, e respondia diretamente a Lisboa. Só será extinto definitivamente em 1774. Segundo SODRÉ, "Daí por diante o Estado do Maranhão oscilará ao influxo de seus extremos, de características diferentes, o Maranhão propriamente dito e a Amazônia" (SODRÉ, p. 126).

O fascínio do ouro breve se mostrará enganador. A colonização portuguesa na Amazônia se restringirá à área em torno do delta do Amazonas, onde se pratica alguma agricultura, especialmente de cana de açúcar, dificultada pela desorganização do mercado de açúcar na segunda metade do século XVII, que a atinge logo na fase inicial de acumulação (FURTADO, p. 84). Expedições são organizadas, dirigindo-se ao interior ao longo da rede hidrográfica, com finalidades de exploração, apresamento de índios e de coleta das drogas do sertão. Estas constituem a única riqueza mais apreciável, e são o cravo, a canela, a castanha, a salsaparrilha e, sobretudo, o cacau, que é também cultivado, junto à foz do Tocantins, próximo a Cametá, fundada em 1635 (SALLES, p. 7; BAENA, p. 40). É a própria pobreza da colônia que obriga à enorme expansão territorial que se efetua, combinando-se o povoamento efetivo da área do delta com um sistema de incursões periódicas ao longo dos rios.

É importante a ação das ordens religiosas. Com elas se acelera a infiltração pelo vale do Amazonas na segunda metade do século XVII. Muitas das expedições ao Tocantins serão realizadas por padres. São eles 
que reunirão os índios e aldeias que darão origem às cidades mais antigas do Pará, localizadas particularmente na zona Bragantina.

Frei Cristóvão de Lisboa, em 1625, é, ao que se saiba, o rimeiro português a subir o Tocantins. Provavelmente não ultrapassou a cachoeira da Itaboca, pois a viagem só durou sessenta dias (BAENA, pp. 30/31).

Seguem-se várias expedições, porém, como diz RODRIUES: "As lutas para a expulsão dos ingleses e holandeses, e a todo custo procuravam se estabelecer no vale amazônico, desviaram do Tocantins as atenções e os esforços do governo Grão-Pará por alguns anos".

Em 1653 dá-se uma expedição que não se pode deixar registrar porque dirigia-a o Padre Antônio Vieira, e porque atingiram o Tacanhonha (Itacaiúnas), que tem o nome da nação "que de mistura com outras dele bebe" (sg. Pe. José Morais, cit. por RODRIGUES, p. 49). Ou seja, chegaram ao sitio onde hoje se encontra Marabá.

Dois anos depois, o Padre Francisco Veloso, a mando Vieira, volta ao mesmo sítio, na foz do Itacaiúnas, trazendo consigo de volta mil e duzentos índios (sg. Bettendorf, cit. por RODRIGUES, p. 51).

Seguem-se mais algumas entradas, e em 1669 Gonçalo Paes e Manuel Brandão descobrem cravo, canela e castanha no Tocantins, aparentemente além da Itaboca. Segundo BAENA (p. 96), alcançam a foz do Araguaia ${ }^{1}$.

Pelo final do século, o Tocantins já fora todo percorrido, e havia a idéia de alcançar-se por ele as esperadas minas de Goiás. Do Sul apareciam algumas bandeiras paulistas preando índios ${ }^{2}$.

1 "Com o intento de esquadrinhar minas de ouro ou prata, Gonçalo Paes e Manoel Brandão girarão e correrrão as florestas do rio Tocantins entre a foz do rio Araguaia, e a paragem onde o mesmo Tocantins começa a mostrar-se abrolhado de penedos e cataratas; e vagueando nesta pesquisa encontrarão arvores de cravo e canella, das quaes troucerão uma porção para certeza apodictica de existência destas plantas nas terras d'aquelle rio; tendo achado também nas campinas das Mangabeiras, Castanheiros de cincoenta e dois palmos de circunferencia, e consequentemente de dezessete e um terço de diâmetro".

${ }^{2}$ (Em 1673) “... na visinhança da confluencia do Rio Araguaia estão infestadas as selvas da Tocantins por um Mestre de Campo da Capitania de São Paulo chamada Pascoal Paes de Araujo que he a cabeça de uma Bandeira de Paulistas, e que atribula as Indigenas Guarujás com a escravidão..." (BAENA, p. 100).
Todas essas expedições em geral tinham pelos menos como um de seus objetivos a descoberta de metais preciosos. Tal é o caso por exemplo do Pe. Antonio Rapozo Tavares, vindo de Lisboa em 1675 com essa inquisição expressa (BAENA, p. 103). Quanto a esse objetivo, no entanto, frustram-se todas.

Em 1694 começa a surgir à margem do Tocantins, acima de Cametá, um aglomerado que daria origem a Baião (MOURA, p. 95).

$$
* * *
$$

Como se vê, trata-se de um movimento intermitente, de pouca consequência real para a área que nos interessa. Desse ponto de vista, embora mudando em parte os móveis, o século XVIII quase todo não oferece grandes modificações.

No Pará, assim entendida basicamente a zona em torno de Belém, dáse um lento crescimento da população na primeira metade do século, com um certo incremento das atividades agrícolas. Nos primeiros anos do século, desenvolve-se a criação de gado em Marajó (a Ilha Grande de Joanes), de importantes consequências para o futuro. Ao mesmo tempo, aumenta o interesse da Coroa pelas drogas do sertão, dada a perda do mercado das especiarias no Oriente com a derrocada do império luso (SOARES, p. 114).

Em 1721 efetua-se a primeira exploração em maior profundidade do rio Itacaiúnas, o principal afluente da margem esquerda do Tocantins entre a Itaboca e a foz do Araguaia ${ }^{3}$.

Em 1724 Bartolomeu Bueno da Silva Filho, vindo de Goiás, desce o Tocantins até Belém (ALMEIDA, p. XIII).

A partir da segunda metade do século, o Maranhão toma a liderança em matéria de atividade agrícola. Já se criara uma companhia de comércio cuja atividade seria extremamente importante no desenvolvimento da agricultura. A guerra de independência dos Estados Unidos e o começo da Revolução industrial fornecerão a criação de condições de mercado

3 "Entra a Jesuita Manoel da Mata pela rio Tacaiunas, um dos concorrentes com o Tocantins, em observância da Ordem Superior para missionar assim os Selvagens de quem o citado rio assume o nome, como as Guaranizes, e outras cabildas de homens de pelle avermelhada" (BAENA, p. 143) 
favoráveis ao algodão na Europa. Diante dessa solicitação, importou-se consideráveis quantidades de mão-de-obra escrava africana.

A guerra de independência dos Estados Unidos já oferece, também, condições favoráveis ao cultivo do arroz, consumido no Sul da Europa, e que, como lembra FURTADO (p. 111), não sofria restrição de nenhum pacto colonial.

Numa época em que o Brasil como um todo encontrava-se em depressão econômica, com a decadência das atividades açucareiras e mineradoras, o Maranhão passa por sua idade de ouro. O Pará acompanha, mais modestamente, este surto, reafirmando o caráter de autonomia relativamente ampla de que gozava em relação ao restante das possessões portuguesas sul-americanas. $\mathrm{O}$ cultivo do algodão, menos adaptado à umidade do que o açúcar, avança no Maranhão pelo interior, alcançando uma certa distância da costa ao subir o Itapicuru e concentrar-se em Caxias, a antiga Aldeias Altas.

Logo depois das guerras napoleônicas, esta economia entra numa decadência da qual só se recuperará, no seu lado amazônico, mais de meio século depois. Do lado maranhense, haverá um curto período de prosperidade algodoeira durante a Guerra de Secessão norte-americana. O final desse conflito, bem como a entrada no mercado europeu, logo depois, do algodão egípcio, praticamente acabará de expulsar do mercado externo o algodão brasileiro.

Essa decadência do início do século XIX é acelerada, especialmente no Pará, devido à deterioração já iniciada no sistema de exploração da mãode-obra indígena, estruturado pelos jesuítas, desde a sua expulsão por Pombal. Os problemas de mercado dificultam, no caso do Pará, que se atrasara em relação ao Maranhão, a sua substituição por mão-de-obra africana.

As consequências do surto agrícola havido sobre o médio Tocantins foram modestas, já que a área cultivada não ultrapassou a foz do rio, e não se buscava mercados no Sul, o que, isto sim, justificaria a sua utilização como via preferencial de comunicação no sistema amazônico.

Apenas a exploração das minas na área das cabeceiras do Tocantins, em Goiás, a partir de 1725, provocou algumas sortidas em direção ao Sul. Todavia, mesmo isto foi prejudicado pelo receio que tinha a Coroa de que o rio fosse utilizado para o desvio dos metais preciosos para o Norte onde os aguardavam navios de contrabandistas estrangeiros, ao invés de seguirem a via obrigatória que ia dar no Rio de Janeiro. Esse risco aumenta com a progressão da frente mineradora no sentido sul-norte e a fundação dos estabelecimentos de São Félix e Natividade por colonos partidos do Pará. Por isso mesmo, em 1737 uma Provisão do Conselho Ultramarino proíbe a navegação do rio Tocantins (ALMEIDA, pp. XIV-XV).

Somente no final do século XVIII, com a decadência da atividade mineradora, é que será reaberto, buscando-se na ligação entre Goiás e Pará um novo estímulo econômico. Dão-se algumas expedições organizadas por comerciantes de Goiás e do Pará com auxílio dos governos, as quais gastaram meses para percorrer o rio. Mas não se chega a estabelecer uma linha regular.

O início do século XIX encontra em franca decadência uma das frentes que produzira algum efeito indireto sobre a área que nos interessa a mineradora goiana, a que se seguiria, pouco depois, a decadência da frente agrícola paraense e maranhense.

Em 1781, com a fundação no Tocantins, a $270 \mathrm{~km}$ de Belém, do posto militar e fiscal de Alcobaça, já próximo a Itaboca, atinge-se o limite da colonização mais efetiva do rio partida do Pará, que tivera como marcos anteriores a fundação de Cametá em 1635 e a de Baião em 1694.

Por esta época, no entanto, já se aproximava da região uma outra frente, que traria resultados muito mais profundos e duradouros para o médio Tocantios: a frente pastoril baiana.

Que veio a se constituir no aglomerado mais importante do Pará depois de Belém. Em 1801, ao passo que Belém possuía 12.500 habitantes, Cametá possuía 7.900 (BAENA, p. 247, de acordo com um Mapa da população da Província enviado para a Secretaria de Estado dos Negócios da Marinha e Ultramar). 


\section{A FRENTE PASTORIL}

A expansão da pecuária no Brasil nos seus primeiros tempos esteve intimamente ligada à economia açucareira. De início o consórcio entre o açúcar e o gado vacum vindo de Cabo Verde era inclusive geográfico. Tratava-se simplesmente dos animais necessários ao funcionamento da plantation.

Todavia, a própria expansão da economia açucareira obrigou a que se reservassem as férteis terras próximas ao litoral para a cana. Na qualidade de atividade subsidiária, e impulsionada pelo dinamismo da atividade principal, o gado vai-se internalizando. Os dois principais centros de dispersão seriam Salvador e Olinda. A partir do primeiro desenvolve-se uma frente que vai interessar ao nosso estudo, e que breve alcança as margens do rio São Francisco.

A rapidez da expansão deve-se também à abundância de terras combinada com a sua baixa produtividade. PRADO JR. calcula que se teria em média duas cabeças de má qualidade por quilômetro quadrado (PRADO JR., p. 44). Aos poucos, as condições vão fazendo surgir o raquítico gado curraleiro ou pé-duro, que se tornaria típico.

Por outro lado, dentro do sistema produtivo empregado, a exigência de mão-de-obra era pequena, cada vaqueiro podendo cuidar de duzentas a trezentas reses. A partilha constituía a base das relações de trabalho: em geral, depois de cada cinco anos, o vaqueiro recebia, como pagamento de seus serviços, a quarta parte das crias. Assim, depois de algum tempo, podia estabelecer-se por conta própria.

Criava-se, desse modo, um princípio dinâmico endógeno, ligado à reprodução do rebanho, às fracas condições naturais, à disponibilidade de terras e às relações de trabalho estabelecidas. As relações com o litoral, agora mais indiretas, vão-se dando através das feiras de gado.

A partir da segunda metade do século XVII, com a lenta decadência da atividade açucareira, esse princípio interno irá sobrepujando a própria demanda de mercado como razão da expansão. As relações com a economia açucareira, especialmente para as fazendas mais afastadas, se enfraquecem e se invertem, com a sua própria decadência lhe trazendo mais um estímulo, à medida que expulsa pessoal que se engajará nessa atividade. Isto fará com que haja uma tendência crescente à pecuária fechar-se sobre si mesma, como atividade de subsistência, numa espécie de involução e marginalização que é a contrapartida de sua maior autonomia em relação à plantation. Tenderá, também, a tornar-se cada vez mais ultraextensiva, com um nível de investimento baixíssimo.

Isto não se dará uniformemente em toda a pecuária, o que criará tipos distintos. Será tanto mais verdade quanto mais afastado se esteja dos mercados. É o que irá ocorrer como caso-limite no Brasil Central, onde há indícios de que a acumulação de gado, mesmo em anos recentes, terá, inclusive, perdido, em certas zonas, parte de seu sentido mais estritamente econômico, para transformar-se em símbolo de status; por vezes quase inegociável.

Esse isolamento também será responsável por uma expressiva permanência dos padrões da pecuária da época da colônia no Brasil Central; em certas zonas até os dias de hoje ou até bem recentemente. Toda a força do sistema transparece na segurança da afirmação de um informante entrevistado na localidade de Estreito, no município de Carolina (Maranhão), em janeiro de 1969, e que pode projetar alguma luz também sobre o passado: o "certo" é a partilha, pois "Aqui não é como no Sul, onde o patrão paga para não ter de dar as crias".

$* * *$

Como diz Furtado, "os criadores mais distantes se tornavam submarginais" (FURTADO, p. 80); numa situação, aliás, próxima ao limite, em matéria de disponibilidade de terras, distância do mercado e relativa escassez de recursos humanos que lembra a do camponês marginal tal como foi proposto recentemente (VELHO, 1969), o que sugere uma posição estrutural que apresenta analogias significativas, entre as quais,

${ }^{1}$ Todavia, tal como indica MOREIRA NETO referindo-se ao baixo Araguaia, quando as condições começam a mudar, a fração da partilha torna-se cada vez menor, passando a 1:6 ou 1:8 (MOREIRA NETO, p. 87). 
aparentemente, a correlação com uma tendência crescente a que a apropriação real aproxime-se de uma definição familiar ou individual ${ }^{2}$.

De qualquer maneira, isto ocorreu lentamente, tanto no tempo quanto no espaço. Deu-se menos, a partir do São Francisco inferior, para o ramo da frente pecuarista. que penetra em Goiás. E, especialmente, para a que sobe o São Francisco em direção a Minas Gerais, alcançando o Triângulo Mineiro, donde, no final do século XVIII, penetraria em Mato Grosso (CARDOSO DE OLIVEIRA, 1960). Pelo menos enquanto mantém-se como atividade subsidiária, embora, agora, da mineração.

Essa involução deu-se mais no extremo final do ramo que prosseguiria no sentido de noroeste, atravessando inicialmente o São Francisco, penetrando no Piauí pelo interior e alcançando a bacia do Parnaíba.

Cada vez mais, neste caso, que é o que nos interessa mais proximamente, a involução econômica mostrava-se ser o próprio móvel da expansão territorial. Crescia o setor de subsistência da pecuária, onde o gado, além da carne e do leite, oferecia o couro, que se torna a matériaprima por excelência dessa frente.

\section{A Frente Pecuarista no Maranhão e no Tocantins}

Em meados do século XVIII ocupa-se o Sul do Maranhão, no que se denominaria Sertão dos Pastos Bons. Segundo Capistrano de ABREU, em 1761 havia 44 fazendas em Pastos Bons (ABREU, p. 212). A partir daí iniciar-se-ia o avanço para o Tocantins.

Ao mesmo tempo, haveria uma inflexão para leste, com o que iriam ser ocupadas as orlas dos vales Úmidos do Maranhão e encontrar-se-ia na altura de Aldeias Altas (Caxias) uma tímida frente pecuarista vinda do litoral $^{3}$. Para sudeste, a frente baiana iria encontrar a pernambucana na altura do Ceará.

${ }^{2}$ Ver BETTELHEIM sobre a distinção entre apropriação real e formal, em que segue E. Balibar: relação de apropriação real e relação de propriedade (L. ALTHUSSER e outros, Lire le Capital, Paris, 1965, Ed. Maspero).

3 "O rio Itapecuru, que hoje é tão importante rela sua riqueza e navegação, e tem um curso de mais de duzentas e cincoentas leguas, era então bem pouco conhecido. E se acaso os sertões dessa Província não recebessem colonos pelo Piauhy, desde 1730, que occuparão
O movimento em direção ao Tocantins foi ainda favorecido pelo novo interesse que, como vimos, fora por ele despertado a partir do final do século XVIII, especialmente enquanto via de comunicação. Em 1798 uma carta régia ordenava ao governador do Maranhão "que mandasse descobrir o Tocantins pelo lado desta capitania, e aos do Pará e de Goiás que mandassem explorar o dito rio" (CARVALHO, p. 30). Estes movimentos simultâneos terão relação com as questões em torno de limites que se prolongarão, como veremos, por muito tempo. De qualquer maneira, aos poucos surgirão alguns entrepostos ligados à navegação do rio, onde se praticará uma pequena agricultura de subsistência.

Segundo algumas versões, a primeira expedição partida de Pastos Bons, em meio a lutas e apresamento de índios, atinge o Tocarúins em 1806 (CARVALHO, pp. 30/31; CARDOSO, p. 3). Segundo outras, a própria expansão da pecuária, sem maiores oposições, leva a atingir-se o Tocantins (ALMEIDA, p. XVI; MARQUES, p. 602, seguindo o Itinerário de Belfort).

De Pastos Bons saem expedições em todas as direções, e ao mesmo tempo vão-se espalhando as fazendas de gado. Em 1808 surge Riachão a oeste; em. 1811, para leste, Porto da Chapada, origem da cidade de Grajaú. Vão aparecendo fazendas de gado no Manuel Alves Grande, afluente do Tocantins da margem direita, que vão descendo o rio até alcançar o Tocantins. Na margem esquerda do Tocantins, do lado de Goiás, surge em 1810 Carolina, e em 1825 Boa Vista, do Tocantins, atual Tocantinópolis. Em 1831 a Vila de Carolina é transladada para a margem direita do Tocantins, e em 1854, uma vez decidida a questão de limites com Goiás (ver ALMEIDA), é incorporada ao Maranhão (MARQUES, p. 179).

Enquanto isso, em 1809 um alvará do Príncipe Regente criava a comarca do Norte ou de São João das Duas Barras. Tentou-se a sua instalação na margem esquerda, do Itacaiúnas, próximo ao atual sítio de Marabá; porém, por aí ficar muito isolada transferiu-se a sede da com arca para a vila de Palma, mais para o sul em Goiás. Mantém-se no Itacaiúnas um destacamento de tropas de Goiás, que é depois substituído por um do Pará, que se transfere finalmente um pouco para o sul, para a confluência do

successivamente todo o territorio de Caxias até o Tocantins, talvez ainda hoje não fossem conhecidos. Tanto a colonisação do litoral como a dos sertões vierão encontrar-se em Caxias, a antiga Aldêas-Altas, de 1750 em diante, segundo o que podemos colligir de algumas Memorias e documentos antigos" (ALMEIDA, XLI). 
Araguaia com o Tocantins, onde hoje se encontra São João do Araguaia (MELATTI, p. 26), de que iremos tratar adiante.

Havia, então, muita preocupação com o contrabando de ouro, que de Porto Nacional, Natividade, Carmo, Paraná etc. tentava-se desviar, em viagens que levavam de ida e volta cerca de seis meses, para os furos próximos a Belém, onde era vendido, especialmente para ingleses.

Segundo BAENA, que não concorda em que São João do Araguaia tenha origem na comarca de São João das Duas Barras, mandada fundar pelo Governo de Goiás, tratava-se, então, por parte do Governo do Pará, da transferência de um registro que se estabelecera em 1797 junto a Itaboca, ao qual se pretendera trazer os moradores de Alcobaça, e que visava a "acautelar os extravios do ouro e a deserção para Goyaz, represar a fuga dos escravos de Cametá e as invasoens e insultos dos Selvagens, e facilitar a navegação dando repouso e refresco às pessoas, que se empregarem em tão dilatadas como afanosas viagens" (BAENA, p. 231).

Tratava-se também, sem dúvida, de um capítulo das longas disputas territoriais entre Goiás, Pará e Maranhão nessa região, o que explica em grande parte as divergências entre os vários autores.

De qualquer maneira, é interessante assinalar que pelo menos na altura de São João a navegação do rio e a proximidade da frente pastoril já permitiam uma iniciativa desse gênero. Daí até Alcobaça é que praticamente continuou a nada haver, apesar do encontro com o Itacaiúnas, mesmo então, já ser vislumbrado como um sítio a ser considerado neste trecho.

Cria-se, ainda, uma linha de correios Belém-Rio passando pelo Tocantins ${ }^{4}$, como alternativa para a via marítima, muito dificultada para a navegação a vela devido à existência de ventos contrários no seu primeiro trecho.

${ }^{4}$ Em 1809 o Furriel Joaquim Antônio de Macedo, enviado ao Rio de Janeiro para comunicar à corte a capitulação de Caiena, “... subio o rio Tocantins até Porto Real da Pontal (O.G.V.: atual Porto Nacional) na Comarca do Norte da Capitania de Goyaz; do dito porto caminhou pela nova estrada construida pelo Governador Dom Francisco de Assis Mascarenhas até aõ Registo de Santa Maria, a qual terá obra de cento e vinte legoas de longor: e deste Registo trãsitou pela Capitania de Minas Geraes á sua Capital Villa Rica, e desta passou aõ Rio de Janeiro. Gastou em toda a jornada noventa e tantos dias, porque chegou nos fins de Maio" (BAENA, p. 277)
Porém o fundamental é que o Tocantins ia assumindo o seu papel de articulador da área pastoril com o Pará. Apareciam algumas pequenas fazendas em suas margens, que serviam de pousada. Já havia comerciantes que se estabeleciam com o intuito de abastecer o Sudoeste do Maranhão de sal, tecidos, ferragens, através de Belém, em vez de, por exemplo, através de Caxias. Por vezes os seus entrepostos se transformavam com o correr do tempo em pequenas vilas. A ligação econômica com o litoral maranhense, portanto, desde essa época, mantinha-se bastante frouxa; ainda mais dada a decadência da economia algodoeira. Era disputada inicialmente pelo poder de polarização da Bahia, e depois pelo Pará; tal como, em nossos dias, também pelo Nordeste e pelo Sul do país.

Todos esses contatos, no entanto, até época relativamente recente, não devem ser exagerados: mantém-se em geral um alto grau de isolamento (a que faz exceção, em parte, a época do auge da borracha); o que não impede que a sua quase excepcionalidade lhe confira significado quando percebidos, não em função da experiência cotidiana dos habitantes da área, mas com a óptica da história.

Durante toda a primeira metade do século XIX e boa parte da segunda prossegue a expansão pastoril no Maranhão. Atravessa-se o Tocantins e vai-se ocupando os campos do Norte de Goiás entre o Tocantins c o Araguaia. Para Leste, por volta de 1840, cria-se Barra do Corda, junto a um afluente do Mearim. E em 1868 surge São Vicente, atual Araguatins, já na margem goiana do Araguaia. A expansão, agora, parece fazer-se mais lentamente, talvez pela melhor qualidade das pastagens que permitiria uma densidade relativamente maior de cabeças de gado, mas também devido à resistência dos grupos indígenas Timbira e à proximidade crescente da orla da floresta amazônica e dos vales úmidos a Leste.

É importante fixar a ideia de que o caráter dessa frente pecuarista tornava-a inseparável dos campos naturais. Numa espécie de círculo vicioso, seu isolamento e sua baixa produtividade não permitiam investimentos maiores, cuja ausência, por sua vez, ajuda a perpetuar suas características. Nessas condições, a mata se lhe apresentava como um obstáculo praticamente intransponível, e permaneceria basicamente como uma espécie de reserva, a ser explorada, como veremos em outro capítulo, no nosso século. 
As novas vilas que surgem para o lado do Tocantins, bem poucas, aproximam-se da floresta, e, por isso mesmo, pouco podem se distanciar das já anteriormente fundadas que ficam para trás, ao contrário do que ocorria anteriormente.

Obviamente, não se trata aqui de um determinismo geográfico absoluto, mas da face que apresenta o meio físico para a sociedade tendo em vista um certo desenvolvimento histórica das forças produtivas.

Em 1852, por iniciativa do Governo maranhense, preocupado com as pretensões territoriais do Pará, funda-se Porto Franco, diante de Boa Vista ${ }^{5}$. No mesmo ano, pouco abaixo no rio, os paraenses fundam Santa Teresa da Imperatriz, que mais tarde passaria ao domínio do Maranhão (RODRIGUES, pp. 118/121).

Talvez só mesmo questões políticas pudessem levar à fundação desses dois povoados, o que denuncia os limites da expansão pecuarista. Porto Franco manteve-se durante boa parte de sua história à sombra de Boa Vista. Imperatriz foi quase um equívoco: de fato os campos naturais contínuos terminam entre Porto Franco e Imperatriz; o que se tem, daí por diante, são pequenas manchas de campos falsos, que aparentemente enganaram os fundadores.

Imperatriz é bem um símbolo dos limites dessa expansão. Durante anos manteve-se estagnada, e quando finalmente é alcançada pela BelémBrasília em 1958, sua população não passa de três mil habitantes. As palavras que lhe reserva CARVALHO, escritas na década de vinte deste século, são as mais amargas e pessimistas (CARVALHO, pp. 192/195), e ROORIGUES, na década de 40, assim se expressa: "Esta pobre cidade, por falta de transportes fáceis e clima saudável, não progride: vegetal" (ROORIGUES, p. 122). O pouco desenvolvimento que ainda assim teve, deveu-se a suas ligações comerciais com Marabá. Não se suspeitava o extraordinário crescimento que experimentaria a partir de 1958.

A vila do Tocantins maranhense que conheceu crescimento mais contínuo e promissor até o advento da Belém-Brasília parece ter sido sem dúvida Carolina, para onde RODRIGUES preconizava a transferência da capital do Estado (RODRIGUES, p. 115).

\footnotetext{
${ }^{5}$ Em zona onde já havia alguma agricultura e pecuária, o que leva a certa controvérsia sobre
} a data de fundação.

\section{O Burgo do Itacaiúnas}

Na última década do século estoura um sério conflito na área de Boa Vista do Tocantins. Os autores são bastante contraditórios na apreciação dos acontecimentos ${ }^{6}$, o mesmo ocorrendo com a memória social. Aparentemente, os problemas tiveram origem mais remota na chegada de uma missão de frades italianos por volta de 1840, encarregada de civilizar os índios Apinagé. Suas atenções parecem ter de fato se voltado preferencialmente para a população neobrasileíra. Aos poucos foram exercendo grande domínio, chegando a ponto de fechar escolas e proibir a leitura de livros. Sua luta principal voltava-se contra a maçonaria.

Essa atmosfera termina por envolver em conflitos a autoridade civil e a religiosa, os quais se agravaram após a proclamação da República, com a entrada de outros fatores em jogo.

Neste remoto sertão do Norte de Goiás, as questões locais vão-se ajustar aos conflitos nacionais, particularmente com a subida ao poder de Floriano Peixoto, quando no Estado de Goiás se acende a luta entre os florianistas, chefiados por Leopoldo Bulhões, e um partido católico, liderado pelo Cônego Xavier (AUDRIN, p. 60.).

Em todo o Estado, acabam por se impor os florianistas, o que leva inclusive à substituição de vigários locais (CARVALHO, p. 205). Todavia, em Boa Vista, a "cidade santa da fé", onde havia particularidades que vinham de antes, estoura uma verdadeira guerra civil, que vai de 1892 a 1894. O positivismo e o Governo Central são vistos como inimigos da fé católica. Esta Guerra da Boa Vista, por suas proporções, mantém-se até hoje como um fato extremamente vivo para os moradores de toda a região.

Apesar da intervenção de forças estaduais, e em parte exatamente devido a essa intervenção, em face da enorme violência com que se dá, os florianistas são derrotados e praticamente banidos. A anistia concedida por Prudente de Morais, mais tarde, "sanccionou o fato consummado" (CARVALHO, p. 208).

Em consequência da derrota, ocorre um verdadeiro êxodo do partido florianista, que irá, por assim dizer, escrever o último capítulo da expansão da antiga frente pecuarista de origem baiana. É de se imaginar, aliás, que

\footnotetext{
${ }^{6}$ Ver AUDRIN. pp. 60/62, e CARVALHO, pp. 55/57 e 205/208.
} 
por trás dos conflitos e do êxodo posterior se escondessem questões de terras, além da atração exercida pela possibilidade de realizar o fornecimento de carne à frente extrativista da borracha que se ia desenvolvendo na Amazônia, e da qual trataremos adiante.

Para Oeste, a corrente de criadores cruza o Norte goiano, atravessa o Araguaia e vai ocupar os campos da Barreira, os últimos campos naturais, já no Pará, nas bacias do Najá, do Arraias e do Pau d'Arco (MOREIRA NETO, p. 11), acabando por dar origem a Conceição do Araguaia. Em 1897, segundo COUDREAU (1897, p. 70), já lá havia 2.500 cabeças de gado.

Para o Norte, um ramo menor desceu o Tocantins na direção do Itacaiúnas. Aos poucos havia se cristalizado a crença, que se manteve por muito tempo, de que por trás das florestas que margeiam o Tocantins paraense - e que julgavam ser apenas ciliares como em Goiás e no Maranhão encontrar-se-iam extensos campos naturais que se prolongariam até o Xingu. Trata-se de uma ficção que teve enorme curso, como se fosse uma verdadeira exigência ideológica da frente que ia encontrando os seus limites de expansão, e que perduraria durante muitos anos. A descoberta dos campos de Conceição, que de fato se interrompem muitos antes do Xingu e que, mesmo assim, não encontram similar mais ao Norte, deve ter reforçado essa convicção ${ }^{7}$. E é assim que esses criadores se embrenham nos domínios da floresta amazônica, mal suspeitando a completa reviravolta que se iria operar no seu modo de vida.

Ambos esses movimentos - para Oeste e para o Norte - são vistos pelo Governo do Pará como uma oportunidade de afirmar o seu domínio sobre os limites litigiosos entre os três Estados, tendo em vista, agora, especialmente as ríquezas extrativas vegetais. Esperava-se também, provavelmente, que permitisse a criação de uma fonte de abastecimento para a frente extrativista, a qual tendia a absorver todas as energias dos seus protagonistas, bem como realizar a antiga intenção que se prolongará até

${ }^{7}$ Em 1896 chega-se a afirmar a descoberta dos famosos campos por uma expedição dirigida pelos irmãos Pimentel, o que provocou um grande interesse na capital do Estado, e o surgimento de um projeto de estrada de rodagem para ligá-los ao rio. Inácio MOURA, que percorreu a região em 1896, chegou a afirmar em seu livro ter verificado onde começavam os ditos campos, a 30 ou 40 quilômetros do rio. E CARVALHO (pp. 208/213), escrevendo na década de vinte, ainda acreditava na descoberta dos Pimentel. meados deste século de tornar Belém menos dependente do gado de Marajó. Numa manobra política, apóia os colonizadores e coloca-os sob a sua égide.

O movimento para o Norte toma um caráter semioficial. Embora muitos dos refugiados se espalhassem a beira-rio, o grupo maior, liderado por Carlos Leitão, antigo deputado provincial, recebe em 1895 um auxílio de 10 contos de réis do Governador Lauro Sodré para fundar uma colônia.

Como ponto inicial da colonização, donde partiriam em busca dos campos, fundam, então, após uma experiência, inicial frustrada junto à foz do Itacaiúnas, o Burgo Agrícola do ltacaiúnas, na praia dos Quindangues, à margem esquerda do Tocantins, $8 \mathrm{~km}$ a jusante da foz do Itacaiúnas, em sítio alto e livre de enchentes. Tratava-se de trecho do Tocantins ainda praticamente desabitado, a não ser, cerca de 25 quilômetros abaixo, na Praia da Rainha e no Lago Vermelho, por alguns maranhenses e goianos recémestabelecidos, realizando um pequeno comércio de caça, peixe salgado e produtos de roça, que daria origem a Itupiranga.

Desde o início, os habitantes do Burgo tinham seus olhos postos sobre o Itacaiúnas, caminho para o Oeste; mas antes pretendiam desenvolver uma colônia agropecuária, aparentemente com laivos de colonização planejada, onde a expressão Burgo trai protótipos europeus ${ }^{8}$.

Os fundadores do Burgo têm muita dificuldade em manter-se fiéis à criação e à agricultura que se pretendia desenvolver. O surto da borracha estava no auge na Amazônia, e embora a área não fosse das mais privilegiadas sob este aspecto, esparsamente inicia-se, a partir de 1897, a sua exploração no Tocantins. A castanha também ia, em face das dificuldades, começando a exercer a sua atração.

Três viajantes que passaram pelo Burgo entre 1896 e 1899 registraram as suas impressões. Estas vão desde um entusiasmo bastante

${ }^{8}$ Por essa época, aliás, fizeram-se diversas experiências mal sucedidas de colonização agrícola na região Bragantina, próximo a Belém, com imigrantes franceses, italianos e espanhóis (ANDRADE, p. 49, citando EGLER, Eugênia Gonçalves - "A Zona Bragantina do Estado do Pará", Revista Brasileira de Geografia, Ano XXIII, No 3, Rio de Janeiro, 1961); e COUDREAU, repetindo observação de outros e referindo-se à região do Burgo, dizia: "Il me paraît que cette région de fortes collines bordant la rivière conviendrait parfaitement à la colonization européenne" $(1897$, p. 68). 
grande da parte do primeiro, Inácio MOURA (pp. 250 e seguintes: "as plantações eram magníficas”; mais de 22 ha de plantação; 222 pessoas; “ ...um dos serviços mais profícuos deste importante lapso governamental"), passando pelo ceticismo do segundo, Henri Codreau, até chegar-se ao pessimismo declarado do italiano BUSCALIONE, o terceiro 9 .

${ }^{9}$ COUDREAU, em missão de exploração do Governo estadual, uma de diversas realizadas na época da borracha, passou pelo Burgo em 1897, e dá-nos conta de suas vicissitudes iniciais. Suas observações merecem transcrição por se referirem a um momento-chave:

La population totale actuelle du Burgo est, d'apres M. Carlos Gomes Leitão, le directeur, de 80 personnes, hommes, femmes et enfants.

Le Burgo actuel a été commencé en juin dernier, ce qui donne actuellement (février 1897) moins de neuf mois de travail - toujours d'apres M. Carlos Gomes Leitão qui m'a fourni, concernant le Burgo, tous les renseignements que já n'ai pu prendre ou controler par moi-même.

L'état sanitaire du Burgo, après comme pendant les défrichements, a été satisfaisant. Ne sont morts, n'ont été gravement malades que ceux qui étaient revenus de la première tentative - la Tapera du confluent de l'Itacayuna déjà intoxiqués par ce milieu malsain ou l'impaludisme tua, en neuf mois environ, 19 colons sur 100 environ que Carlos Leitão amenait avec lui; mortalité énorme de 25 pour 100 par an!..

Le personnel des survivants restés fideles se compose-t-il de bons agriculteurs et d'agriculteurs laborieux? Il paraît malheureusement évident qu'il faut répondre à cette double question sinon par une négative absolue, du moins avec une foule de restrictions, de réserves, de réticences. Il semblerait que les 'colonos' auraient assez peu de goût ou d'aptitudes pour leur métier d'agriculteurs, - ou peut-être encore que le travail 'en grande famille', sous une hiérarchie, sous une direction, ne leur plairait guère et qu'ils préféreraient les risques et les difficultés du travail individuel, l'indépendance qu'il peut procuret semblant être pour eux le souverain bien. Les tentations du travail de la borracha et même de la castanha paraissent être aussi sur eux d'un assez puissant effet car déjà un certain nombre des 'colons' ont quitté le 'burgo' pour se faire seringueiros ou castanheiros. $\mathrm{Ce}$ nombre est encore restreint, une demi-douzaine tout au plus, mais l'exemple est contagieux... D'autres quittent volontairement le Burgo pour s'établir à des distances plus ou moins grandes, faisant d'abord une roça pour avoir le temps de s'orienter dans l'avenir. Toutefois ceux qui se désagrègent, seringueiros, castanheiros, roceiros, ne sont-ils encore qu' une petite minorité, le plus grand nombre reste au Burgo et paraît vouloir y rester... quitte à profiter des récentes découvertes qu'on a faites de seringaes voisins, sans abandonner, complètement, du moins tout de suite, ce pauvre Burgo Agricola déjà menacé bien qu'encore fort insuffisamment assis sur ses bases..
Nos anos seguintes, as perspectivas de desenvolvimento agropecuário se tornariam cada vez mais remotas. Já não era apenas uma pequena minoria que se internava na mata em atividades extrativas, as quais, por sua vez, iam-se definindo mais claramente pelo caucho. O futuro da área estava como que decidido por muitos anos. Ligar-se-ia necessariamente à extração, em função da qual surgiria e tornar-se-ia conhecida Marabá. O Burgo desapareceria $^{10}$, e com ele entrariam em longa hibernação os sonhos agropecuários dos colonizadores, para só ressurgirem muito depois, com nova feição.

Les plantations, au Burgo, ne consiste encore qu'en manioc, riz, mais et canne à sucre, cultures d'ont l'étendus totale est modeste pour une population de 80 personnes..

Le bétail est la pièce de résistance dans l'inventaire des richesses du Burgo. Le 'burgo' aurait, paraît-il, une centaine d'animaux d'espèce bovine, boeufs, vaches et veaux, dans le pâturage malheureusement trop petit de 1'Ilha de João Vaz d'ailleurs presque completement noyée pendant l'hiver et ne se prêtant guère à l'élevage. Il est vrai qu'il n'existe pas de campos naturels dans toute la région voisine $(1897$, pp. 65/67)

Dois anos depois, eis o que dizia Luigi BUSCALIONE, o outro viajante:

Il Borgo agricolo d'Itacajuna rappresenta un centro intelectualle di una certa importanza, poichè havvi una scuola elementare. Il colonnello Leitão sognò di transformare il borgo in una fiorente colonia ed a tal uopo fece richiesta di denaro e di terre al Governo del Pará che generosamente non solo lo aiutò con una bella dose di Contos, ma lo fece persino padrone di un territorio grande quanto una piccola provincia d'Italia e ricco straordinariamente di piante a caucciù. Il Leitão coi suoi addetti cominciò a dedicarsi all'allevamento del bestiame, ma la colonia anziché prosperare andó mano a mano deperendo, tanto che oggi si trova ridotta a mal partido. E vero che si pratica ancora attualmente l'allevamento de buoi in un isola situata in prossimità del Borgo, ma la maggior parte degli uomini si è data da due o tre anni alia vita del bosco in cerca di caucciù, mentre quei pocho che sono rimasti nel villaggio attendono più volontiere al minuto commercio (BUSCALIONE, pp. 26/27).

${ }^{10}$ Em 1914 estava reduzido a “... um sítio collocado em um terreno alto, plantado de laranjeiras e d'outras arvores fructíferas, em frente ao rio...” (BUARQUE, p. 43). PATERNOSTRO, que viajou no Tocantins em 1935, já não faz nenhuma menção a ele. 


\section{A EXTRAÇÃO LIVRE}

A Amazônia permaneceu séculos numa situação de grande marginalização em relação ao mundo, mas especialmente em relação ao próprio Brasil. Isso se agravou com a desintegração do sistema de exploração da mão-de-obra indígena dos jesuítas e a decadência da zona agrícola. As comunicações se davam diretamente com Lisboa, e não é por acaso que lá se organizou um dos focos de resistência ao movimento de 1822.

Todavia, tal como a economia pecuarista subsidiária esteve ligada a uma significativa expansão territorial, o mesmo ocorreu em grau maior ainda com a incipiente extração das drogas do sertão. A diferença está em que a relação com o restante do país foi ainda mais precária e muito mais acidental.

O território que com isso se assegurou para o futuro foi dos mais expressivos. Isso se deveu em parte à fraqueza do movimento de expansão vindo do Pacífico, dado o tipo de economia que lá se desenvolveu, fundamentalmente concentrada para oeste do obstáculo físico dos Andes desde a descoberta das minas. Deve-se também à orientação do eixo principal de penetração - o Amazonas, e ao gênero de ocupação que se afirmou: ralo, linear, ao longo dos rios. A floresta manteve-se em grande parte intocada, embora em termos políticos relativamente assegurada. Era o que se podia realizar em face da orientação colonial e mercantil da exploração e dos atrativos que nesse sentido oferecia a região.

O Tocantins, cuja navegação oferece algumas dificuldades, seria, em certo sentido, o anti-Amazonas. Seria, por excelência, o meio de comunicação potencial com o restante do país. O interesse ou desinteresse por ele constituiriam uma espécie de termômetro dessas ligações e da existência ou não de móveis reais para isso.

\section{O Ciclo da Borracha}

Desde a década de vinte do século XIX, registra-se alguma exportação de borracha amazônica; uma dentre diversas drogas do sertão. Todavia, é a partir da segunda metade do século que a exportação realmente torna-se preponderante. Deve-se aos novos usos industriais que se ia descobrindo para ela, o que alcança um clímax a partir do final do século, quando, como assinala FURTADO (p. 156), a indústria de veículos terrestres a motor de combustão torna-se por muito tempo o principal fator dinâmico das economias industrializadas.

Estabelece-se na Amazônia um sistema de exploração extremamente rudimentar das árvores nativas que davam a goma - a seringueira e o caucho, e altamente dependente, para qualquer aumento de produção, do afluxo de mão-de-obra c da ocupação de novas áreas. Em meio século afluem à região cerca de meio milhão de nordestinos, numa primeira grande quebra do reservatório de mão-de-obra em que se constituía o Nordeste.

Essa migração em grandes números é facilitada, já na década de 70, por uma situação excepcional que atravessava o Nordeste, dado o fim da guerra civil norte-americana, durante a qual houvera um curto período de prosperidade do algodão nordestino, e devido também às grandes secas do final da década. Os flagelados concentram-se nas cidades litorâneas, onde sua presença constituía um potencial explosivo. E essa própria concentração irá facilitar o seu embarque para a Amazônia. Na verdade, tudo isso se liga, em boa parte e em última análise, às dificuldades crescentes experimentadas pelo dominante e exclusivista, embora decadente, sistema da plantation em absorver os excedentes demográficos, a que não é estranho igualmente o crescimento a partir dessa época do setor terciário nas cidades. Isso surge mais claramente à luz do dia em face do comportamento do mercado externo e da combinação com dificuldades climáticas, que reduzem a capacidade de absorção dos excedentes populacionais por parte dos subsistemas dependentes da plantation no agreste e no sertão, o que vai contrastar com alternativas concretas que surgem, de inicio excepcionalmente, fora da região.

Na Amazônia, irão avançar até ocupar áreas novas - particularmente nos vales do Purus, do Juruá, do Javari e o Acre, conquistado à Bolívia (DIAS, 1969, p. 15).

É a seguinte, em termos aproximados, a evolução da produção da borracha: 
QUADRO I

Anos $\quad 1841.50 \quad 1851.60 \quad 1861-70 \quad 1871.80 \quad 1881.90 \quad 1891.1900 \quad 1901.10$

Quanti-

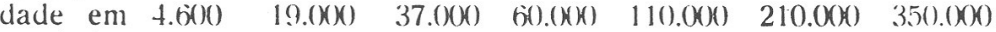
toneladas

(Fonte: FIRTADO, pP. 156/157.)

Trata-se de uma curva fortemente ascendente. A maior exportação anual é alcançada em 1912, com 42 mil toneladas. Em seu auge, a borracha torna-se o segundo produto da nossa pauta de exportações, logo após o café, e é responsável por cerca de 40\% do valor global da exportação. Em 1905, em face dos preços declinantes do café, a exportação de borracha chega a superá-lo (SODRÉ, p. 310). A Amazônia, de uma hora para a outra, alcançara máxima importância nacional e internacional.

Mais do que o aumento da produção, porém, subiam os preços no mercado internacional, devido a sua posição privilegiada. Eis em libras a evolução dos preços médios por tonelada nos primeiros decênios:

QUADRO II

\begin{tabular}{ccccc}
\hline Anos & $1841-50$ & $1851-60$ & $1861-70$ & $1871-80$ \\
\hline Preços (£) & $£ 45$ & $£ 118$ & $£ 125$ & $£ 182$ \\
\hline
\end{tabular}
157).

No triênio 1909-11, atinge-se 512 libras por tonelada (FURTADO, p.

Essa evolução indicava que a oferta não conseguia acompanhar a procura, apesar de todo o esforço humano envolvido. Com isso, forçam as grandes nações industriais a solução da borracha oriental cultivada, nas atuais Malásia, Indonésia, Tailândia e Ceilão. A partir de 1912 caem os preços da borracha, o que se acentua após a I Guerra Mundial, por fim estabilizando-se abaixo de 100 libras por tonelada, até a sua substituição parcial pela borracha sintética.
Desfazia-se o sonho amazônico, do ponto de vista das nações industriais mera solução provisória da qual não podiam depender permanentemente. A exploração mais sistemática da borracha, no Pará, vai reduzir-se praticamente às primeiras seringueiras a terem sido exploradas: as de Marajó e do baixo Amazonas (ANDRADE, p. 41).

\section{A Fase da Extração da Borracha no Médio Tocantins}

Pode-se depreender, dos relatos de MOURA, COUDREAU e BUSCALLONE, três fatos importantes sobre a extração na área do Itacaiúnas na última década do século passado. O primeiro é que, quase desde o início da fundação do Burgo do Itacaiúnas, a extração constituiu uma tentação para os colonizadores, enquanto atividade possivelmente mais viável e rentável. Todavia, percebe-se, como segundo fato, que por esta época, quase o auge do boom da borracha, sua exploração nessa área ainda era bastante modesta. Tanto assim que, como terceiro fato, a castanha, embora produto não suscetível a uma procura exagerada, e de valor relativamente modesto, disputava na área a preferência dos extrativistas.

Aparentemente, seja devido à dificuldade de acesso e desconhecimento da área, seja devido à menor concentração das árvores produtoras da goma, seja porque aí predominava $\mathrm{O}$ caucho, que se demorou a reconhecer ${ }^{1}$, e não a seringueira, seja dada a existência, ainda, de áreas alternativas por explorar, a área manteve-se até essa época como uma reserva. Só mesmo no auge da procura, a partir do final do século, é que se iniciará a sua exploração. Até então, a exploração que havia no Tocantins de borracha e de castanha concentrava-se quase toda no seu curso inferior, onde cidades como Baião, Alcobaça e Arumateua conheceram fugaz prosperidade. As corredeiras da Itaboca parecem ser, ainda, o grande limite. O trecho entre as corredeiras e São João do Araguaia, a não ser por alguns pequenos aglomerados aproximadamente contemporâneos do Burgo que iam surgindo, ainda servia basicamente, apenas como traço de união entre a frente extrativa e a frente pastoril. Já havia estradas de boi do Maranhão c Goiás em direção ao Pará, e durante o verão as boiadas eram conduzidas aproveitando-se a beira-rio.

${ }^{1}$ De acordo com a tradição teria sido descoberto no ltacaíunas em 1896, pela mesma expedição que partiu em busca de campos, devido a um tiro acidental que fez verter a goma. 
Eis os dados de população beira-rio que fornece Coudreau, referentes a sua primeira viagem de $1897(1897$, p. 256):

\section{Quadro II}

\begin{tabular}{lc}
\hline \multicolumn{1}{c}{ Trecho } & População \\
\hline De Alcobaça a Arumateua & 176 habitantes \\
Arumateua & 160 habitantes \\
De Arumateua a Itaboca & 604 habitantes \\
De Itaboca a Água de Saúde & 48 habitantes \\
De Água de Saúde ao B. A. do Itaiúnas & 82 habitantes \\
B. A. do Itaiúnas & 60 habitantes \\
Do B. A. do Itaiúnas a São João do Araguaia & 72 habitantes \\
São João do Araguaia & 200 habitantes \\
De São João do Araguaia a São Vicente & 240 habitantes \\
São Vicente & 160 habitantes \\
\hline
\end{tabular}

Não só o que havia acima da Itaboca até a confluência com o Araguaia era quase tudo bastante recente, mas também estava concentrado na margem esquerda. A outra margem era povoada apenas por índios, que muito se temia, especialmente os Gaviões.

Por essa época, no antigo presídio de São João do Araguaia e logo ao Sul apareciam algumas fazendas, com algumas centenas de cabeças de gado "dans de petites campinas" e, mesmo, "dans de petits campos artificiels" (COUDREAU, 1897, p. 80). São os últimos segmentos efetivos da cabeça de ponte da frente pecuarista no Norte de Goiás, onde avulta São Vicente do Araguaia (atual Araguatins). Não estão tão isolados quanto o Burgo do Itacaiúnas em relação à área pecuarista, e são estimulados por condições excepcionais ao fornecimento de gado à frente extrativista no baixo Tocantins e alhures, o que diminui durante algum tempo o grau de isolamento dessa pecuária do Norte do Brasil Central. COUDREAU em sua segunda viagem, no segundo semestre de 1897, registra a passagem de quatro boiadas de 36, 124, 100 e 70 cabeças, respectivamente. O gado atravessava a floresta virgem por simples trilhas até Arumateua e algumas outras localidades, onde era embarcado. De São Vicente, acima de São João do Araguaia, até Arumateua, numa distância de cerca de 400 quilômetros, levava-se cerca de dois meses (1898, pp. 40/43). Segundo CARVALHO, desde 1873 que por iniciativa do Governo fora aberta uma estrada para fazer descer boiadas do Maranhão e Goiás (p. 204). Uma delas começava próxima a Imperatriz.

Em 1896, no Burgo do Itacaiúnas, ainda não se perdera a esperança de encontrar os campos, e é em busca deles que se realizam diversas explorações do Itacaiúnas dirigidas pelos irmãos Pimentel, os quais, eles mesmos, haviam passado pelo Burgo após conduzir uma boiada do Riachão para Itapepocu, no Pará (CARVALHO, p. 209).

$\mathrm{O}$ rio se revela de difícil navegação. Contraditoriamente, ao mesmo tempo em que se supõe descobrir sinais de campo, de fato a descoberta concreta que resulta das explorações levadas a efeito fundamentalmente com esse propósito é a de cauchais no Itacaiúnas; o que determinaria futuro bem diferente. É essa descoberta que provoca em pouco tempo a desagregação do Burgo, denunciada por COUDREAU e BUSCALIONE. Ao percorrer o Itacaiúnas alguns meses após os Pimentel, COUDREAU já encontrou habitantes recém-instalados no seu curso inferior (COUDREAU, 1898 , p. 55). Enganou-se, porém, ao julgar de pouco valor a exploração do caucho (1898, p. 201), não levando talvez em conta devidamente a crescente demanda pela goma, que nessas circunstâncias já tornava viável a exploração.

E não é só no Burgo que a "vertigem" da extração vegetal, na expressão de COUDREAU, provoca a desagregação. O mesmo registra ele em relação às pequenas aglomerações marginais que haviam surgido (1897, p. 92), e que revelam agora, no momento de seu perecimento, um papel de reserva de mão-de-obra. Era a castanha e o caucho; porém, cada vez mais, só o caúcho.

Na área ao Sul de São João, ao que parece, os povoadores oscilavam entre manter-se ligados à atividade de fornecimento da frente extrativista e seu próprio engajamento direto nela. No final, haverá das duas atividades, e a borracha será explorada mesmo cm Conceição e nos limites do Maranhão com o Pará.

\section{Marabá}

A letargia dos anos anteriores, segue-se uma fase em que em meses dão-se transformações fundamentais para o futuro da região. 
A certeza do caucho atrai multidões de muitas partes, especialmente do Maranhão e do Norte de Goiás, ainda transbordamentos da frente pecuarista; e também do Piauí, Ceará, Paraíba, Pernambuco, Bahia e outros Estados. Aparentemente, na área do Itacaiúnas a exploração da borracha sempre foi livre. Qualquer um que quisesse poderia internar-se na mata em busca da goma.

Desde o início aparece a figura do comerciante, nacional ou de origem sírio-libanesa. Vinham muitos de Grajaú, então importante centro comercial de pecuária e venda de peles, mas também de outros lugares. Podiam ser homens que ao contrário da imensa maioria já traziam algum recurso; ou, então, que se elevavam acima da massa investindo aquilo que ganhavam na própria área no comércio. Numa região em que a terra não constitui bem escasso, não aparece a figura do latifundiário como o poderoso por excelência. $\mathrm{O}$ bem escasso nas regiões longínquas são $\mathrm{o}$ capital e os meios de comercialização. Mesmo na frente pecuarista do Brasil Central, os poderosos eram frequentemente aqueles que combinavam o papel de fazendeiro com o de comerciante. Isso se torna muito mais verdadeiro quando a atividade econômica predominante de modo praticamente absoluto só tem sentido em função do mercado, e de um mercado que não é o local, com o produto não possuindo, para os produtores, praticamente nenhum valor de uso ${ }^{2}$. É assim que os comerciantes vêm a constituir uma camada de extraordinária importância. Aqui, a posse do capital e dos meios e canais de comercialização antecede a questão da posse da terra. São escassos os canais de comercialização, dadas as dificuldades de acesso, os recursos envolvidos que obrigam a certa concentração e os contatos e conhecimentos que exigem, a que não é estranha a política. $\mathrm{Na}$ prática, a partir de certo momento torna-se impossível para a massa dos produtores tentar realizar todas as operações de comercialização por conta própria.

O comerciante, basicamente, interferia em dois momentos. Inicialmente, na venda do material necessário ao indivíduo para que se internasse na mata por semanas e meses a fio a chamada aviação, e, depois, na compra da matéria-prima coletada. A regra geral era que no primeiro momento a venda fosse a crédito, o que implicava, seguidamente, que o

\footnotetext{
${ }^{2}$ Ver MATTA em LARAIA e MATTA, p. 82
}

indivíduo já se comprometia, de antemão, a entregar a goma ao mesmo comerciante.

É por isso que Marabá irá surgir como iniciativa de comerciantes, perpetuando na memória social o seu papel histórico. Sua fundação é um caso exemplar a demonstrar que mesmo em região onde o meio parece dominar de modo tão absoluto o homem, a influência geográfica só pode ser entendida quando mediatizada pelas forças sociais envolvidas, as quais podem ter origem bastante remota e transcendente em relação à própria área.

Já vimos como os primeiros povoadores inicialmente se situaram na foz do Itacaiúnas. Todavia, condições consideradas péssimas, tais como inundações e febres, levaram-nos a deslocar-se para sítio mais favorável, por todos elogiado. No entanto, com a exploração do caucho, a foz do Itacaíúnas ganha novo interesse, pois de lá se domina simultaneamente duas grandes vias de escoamento da região: o Tocantins e o Itacaiúnas com seus afluentes. É por isso que, segundo a tradição, a 7 de junho de 1898 , Francisco Coelho, vindo de Grajaú, inaugurou um barracão de comércio neste sítio, à margem direita do Itacaiúnas, num ângulo agudo formado pelos dois rios ${ }^{3}$. É logo seguido por outros comerciantes. O nome de Marabá, que acabou se referindo ao conjunto de barracões, é inspirado numa poesia de Gonçalves Dias, e teria vindo do nome de antigo estabelecimento comercial de um dos pioneiros, segundo alguns do próprio Francisco Coelho, segundo outros de Francisco Casemiro de Sousa, cearense anteriormente estabelecido em Pedra Afonso. Seu padroeiro veio a ser São Félix de Vallois, por influência, provavelmente, dos dominicanos de Conceição do Araguaia.

\footnotetext{
${ }^{3}$ Numa parte do barracão teria estabelecido o seu comércio, reservando outra para festanças Francisco Coelho junto com alguns sócios já teria estado no mesmo sítio em 1896. Nessa ocasião, conduzia uma boiada de Grajaú para Nazaré dos Patos. Tendo resolvido interromper a viagem para que o gado recuperasse o peso, acabou por vendê-la para os moradores recémestabelecidos a beira-rio, particularmente no Burgo. Com a descoberta do caucho teria regressado a Grajaú para depois transferir-se definitivamente, já então retomando no bojo do fluxo de sertanejos que se dirigiam para a área atraídos pela notícia. A importância do comércio transparece do próprio fato de considerar-se como fundação de Marabá a data de inauguração do barracão de comércio, apesar de por essa época aparentemente já haver um reduto no local.
} 
Não é raro por estas paragens a existência de localidades periodicamente sujeitas a enchentes. São palhoças a beira-rio que todo ano são reconstruídas, após a cheia. Justifica-se, exatamente, em função de sítio privilegiado, como ocorre hoje com a parte ribeirinha de Apinagés, a que nos referiremos adiante, próximo a São João do Araguaia e à confluência do Araguaia com o Tocantins. Obviamente, nessas circunstâncias, nunca se toma providências para melhorar as casas, puramente sazonais.

Marabá, no seu início, era assim. Muito mais do que no caso do Burgo, sua função primordial era o comércio. Seu aspecto urbano miserável contrastava com a riqueza do esplendor da borracha. No entanto, sua importância crescente fez com que posteriormente, mais afastadas da beira do rio, surgissem casas melhores e aos poucos uma verdadeira pequena cidade. Acontece que Marabá encontra-se num sítio particularmente desfavorável, pois afora as enchentes anuais que inundam a beira-rio, de vinte em vinte anos, aproximadamente, coincidem as cheias do Itacaiúnas, do Tocantins e do Araguaia. Nessas ocasiões, ocorrem grandes enchentes, de que não se livram, mesmo hoje, os bairros mais afastados. As piores enchentes se deram em 1926 e 1947, provocando inclusive relatórios governamentais. As grandes enchentes, suas consequências e a expectativa das próximas são assunto constante de conversas em Marabá. Desde a primeira, em 1906, que se discute a transferência da cidade. Pois apesar de tudo ela persiste, o que indica que diante de um fator físico favorável e de outro desfavorável, a resultante não pode deixar de ser uma decisão social; determinada, sem dúvida, mas por forças muito complexas. Algo semelhante poderia ser dito das corredeiras do Tocantins, especialmente da Itaboca, que tanto dificultaram a exploração do rio, porém que diante de um valor mais alto passam a ser arrostadas em rudimentares batelões movidos a remo que realizam o comércio do rio entre Marabá e Alcobaça (atual Tucuruí), até onde penetram embarcações maiores.

Marabá logo prosperou e tornou-se centro de polarização para uma vasta zona, tanto em termos de atração de contingentes populacionais, quanto em face das exigências de abastecimento, dadas as características exclusivistas da atividade extrativa. Diz CARVALHO: "Desde o Piauhi, todo o sertão exportou viveres, carne de boi e de porco; toucinho, farinha sêcca e de puba, assucar, rapadura, cachaça, tabaco, doces, queijos, gallinhas, ovos, bois vivos, porcos e vaccas paridas, até laranjas, abóboras e inhames para a phantastica e maravilhosa Marabá, surgida de repente como obra da magia na foz do escuro rio Tacai-una" (CARVALHO, p. 194).

Imperatriz tornou-se porto movimentado nesse comércio e com a passagem dos nordestinos que demandavam Marabá. Os antigos moradores lembram a importância de Grajaú, Carolina, Santo Antônio de Balsas e de todo o Norte de Goiás no fornecimento de carne seca através de Imperatriz o Porto Nacional. De Belém vinha milho, feijão, batata, arroz etc. Até de Portugal eram enviadas mercadorias.

Em Marabá, propriamente, transformada como que num grande acampamento, todas as energias se concentravam na extração da goma, sorvendo, como "enorme ventre", as mercadorias vindas de fora.

Os comerciantes de Marabá ganham importância extralocal. Sentindo-se abandonados pelo Governo do Pará, criam uma comissão, vão a Belém, manipulam, inclusive, as antigas questões de limites entre os Estados, e alegando estarem por origem mais ligados a Goiás, bem como as dificuldades de comunicação com o Pará, representam a Goiás no sentido de serem incorporados a esse Estado. O movimento surte o efeito de despertar o Governo do Pará, e depois de um primeiro sucesso parcial, acaba tendo efeito completo: em 1913, Marabá ganha sua autonomia municipal, com território desmembrado de São João do Araguaia, que por sua vez, anteriormente, fora desmembrado do então imenso município de Baião ${ }^{4}$.

Marabá se enche de uma população instável, flutuante e aventureira. Desde o inicio é marcada pelo signo da turbulência, de que não se dissocia sua fama ${ }^{5}$.

${ }^{4} \mathrm{O}$ município de São João do Araguaia parece ter sido criado $\mathrm{cm}$ função do mesmo movimento, quando o Governo do Estado do Pará temeu a possibilidade de perder a região para Goiás em vista do movimento iniciado em Marabá e seguido em Conceição do Araguaia. Todavia, o mal-estar provocado fez com que a sede do município viesse a ser São João do Araguaia (1908), levando mais cinco anos até que Marabá ganhasse a sua autonomia.

${ }^{5}$ É significativo o testemunho de D. Domingos Carrérot, primeiro bispo de Conceição do Araguaia, prelazia em cujo estremo norte encontrava-se Marabá, transmitido através de seu biógrafo. Devido à "fabulosa rapidez" com que se desenvolvia Marabá, D. Domingos viu-se obrigado a lhe consagrar parte de seus cuidados: 
Em 1913, ano em que Marabá ganha sua autonomia, contava, então, o povoado, com cerca de 500 habitantes fixos e mais de 1.500 na época de

...Foi esta a principal preocupação dos últimos anos do seu governo no Araguaia. Cada ano, pelo menos uma vez, fazia lá sua visita pastoral, ou mandava algum missionário residir lá alguns meses...

A importância de Marabá provinha da sua posição geográfica e das riquezas do seu território. Afluíam aí numerosas famílias ribeirinhas do Tocantins e do Araguaia, outras do interior do Maranhão, junto com milhares de do Araguaia, outras do interior do Maranhão, junto com milhares de
seringueiros e de castanheiros do Itacaiúnas. Certos meses de safra, a população adventícia atingia a mais de quinze mil pessoas. Entre estas aparecia um sem número de doentes, saídos das matas úmidas, consumidos pela malária, que vinham morrer em barracas imundas sem o mínimo socorro material e espiritual.

Esses detalhes justificam as solicitudes de nosso Bispo a respeito de São Félix de Marabá. Além das misérias físicas e corporais, que diremos das misérias morais, agravadas ainda pelas tentativas atrevidas das seitas protestantes, espíritas e outras para implantar-se por lá?

Marabá não era Conceição (O.G.V.: onde o célebre Frei Gil Vilanova, já envolvido anteriormente nos acontecimentos de Boa Vista, estabelecera uma tradição de grande poder dos padres sobre a vida dos habitantes). Marabá brotara da ganância do dinheiro; logo, totalmente alheia a qualquer preocupação religiosa e moral. Principiou sendo o que chamam 'corruptela', nome bem significativo, empregado com muito acerto nas regiões de garimpos, e que não carece de comentários.

Compreendemos bem os motivos de aflição do santo Pastor. Algumas das pragas morais e sociais mais comuns eram a mancebia e a poligamia, por meio sobretudo do casamento civil. Quantos desses seringueiros, castanheiros esqueciam-se de suas famílias legítimas, e tentavam construir outro lar, servindo-se do contrato civil, passado sem as menores garantias, perante funcionários sem conhecimentos jurídicos e sobretudo sem moral! Não se respeitava nem casamento religioso, nem contrato civil efetuados anteriormente em outros lugares (AUDRIN, pp. 155/156).

É possível que se tenha exagerado a penetração de seitas protestantes e espíritas, pois a autoridade relativamente fraca dos padres não implica necessariamente a força e ousadia de concorrentes, mas, possivelmente, uma atitude mais mercantil e secular no seio da grande massa do que era geralmente o caso em outras áreas. Também os males especificamente do casamento civil parecem ter sido exagerados, dada a sua implantação recente e a posição da Igreja Católica, pois a julgar por épocas mais próximas, mesmo este não era levado muito em conta ou utilizado.

Quase cinquenta anos mais tarde, o "estado moral" de Marabá, com suas casas de farra, ainda impressionaria vivamente outro padre francês: Barruel de LAGENEST. maior movimento (LAGENEST, pp. 14 e 19). O colégio eleitoral compunha-se de 62 eleitores. A exportação de caucho do novo município nesse ano foi de $327.900 \mathrm{~kg}$.

Mas é exatamente então que se inicia a queda do preço da borracha. Em 1921 a produção de Marabá terá descido $92.000 \mathrm{~kg}$, a preços já bem menores, e em 1923 será de apenas $43.632 \mathrm{~kg}$. Trinta anos depois, em 1952 , a exportação estava reduzida a 244 kg (DIAS, 1958, pp. 417/419), e hoje já não é sequer registrada exportação alguma da região de Marabá. Dado que o caucho, ao contrário da seringueira, é derrubado para a extração da goma, é certo que a produção da área iria de qualquer forma declinar. Isso, no entanto, não retira o caráter de dramaticidade provocado pela queda brusca de preços.

A memória social guarda como ano fatal da grande crise a lembrança de 1919. Ao que parece, até então, embora caindo os preços, a produção prosseguia, numa espécie de política de pleno emprego ${ }^{6}$. Mantinha-se como que a esperança de uma alteração que não veio no sentido esperado, antes pelo contrário, com o fim da I Guerra Mundial. Mil novecentos e dezenove é o mesmo ano citado por AUDRIN para Conceição. Lá, segundo ele:

A queda desastrosa do comércio da borracha paralisou as transações e os negócios, e muitas famílias abandonaram nossa cidade e os campos do município, para voltarem aos sertões de onde tinham vindo, nos tempos da prosperidade e das esperanças. Também os garimpos diamantíferos de Mato Grosso atraíam muitos coitados com a miragem dos diamantes.

Principiou então o declínio lamentável que tem continuado até hoje (1946, G.O.V.). É o fenômeno que se repete constantemente nessas zonas remotas dos sertões amazônicos. Prosperidade extraordinária e exagerada de alguns anos, seguida de inegável decadência! (AUDRIN, pp. 162/163).

Marabá já era centro regional mais importante do que Conceição, embora mais rústico; e intimamente ligada, desde a sua fundação, à borracha. Toda a Amazônia iria passar por um longo processo de involução, de que só começaria a se recuperar lentamente por volta de 1940. Um

${ }^{6}$ O que não deixava de provocar grandes tensões. Em 1917 surgiu um sério conflito em Marabá, com várias mortes, provocado por indivíduos que tendo chegado ao povoado para vender a borracha e não encontrando preço, resolveram saquear o comércio local. 
observador situado na época certamente, deveria apostar na decadência de Marabá.

E de fato em 1919 iniciou-se um grande despovoamento. Todavia, por essa mesma época, ocorre em Marabá sério conflito político. O chefe político Anastácio Queiroz, alegando perseguição política, chefiou um movimento que depôs o Intendente municipal, considerado autoritário. Armou a população e enfrentou o destacamento militar enviado pelo Governo do Estado. Este, após uma composição em que o líder do movimento aderiu à situação estadual, reconheceu o novo estado de coisas. Independentemente das motivações por trás do movimento, a verdade é que este dificultou a intensificação do êxodo. Segundo os depoimentos colhidos, todos se mantinham armados, ninguém podia sair e, ainda mais, o comércio sustentava a população. É de se imaginar que tudo isso tivesse ligação com um esforço da elite local, amparada em grupos extra locais, possivelmente exportadores, para não dispersar irremediavelmente a mão-de-obra enquanto se realizavam os ajustes necessários - de produção e comerciais para a transição da borracha à castanha ${ }^{7}$.

Seja como for, em 1920 é praticamente reiniciada a exploração da castanha, que nos últimos anos, a não ser por alguns embarques efetuados já a partir de 1913, servia quase que exclusivamente para o consumo na mata. Em 1913 sua produção em Marabá fora de apenas 20 hectolitros, e em 1914 de 2.502 hectolitros, atingindo 5.396 hectolitros em 1919. Em 1920 irá saltar para 17.878 e em 1921 alcançará 27.965, ultrapassando já a produção do caucho. Neste ano, somente Óbidos produziu mais castanha em toda a Amazônia (O Pará em 1922, p. 8). No final da década uma publicação editada pelo Governo Federal (SERVIÇO DE INSPEÇÃO E FOMENTO AGRÍCOLA, p. 28) já colocará Marabá como o maior exportador de castanha, com a seguinte evolução na sua produção:

${ }^{7}$ Aparentemente alguns borracheiros da região já haviam se associado a comerciantes de Belém para comprar castanha em Alcobaça. Em Marabá o primeiro comerciante que resolveu explorar a castanha era ligado, justamente, a Anastácio de Queiroz.
QUADRO IV

\begin{tabular}{lrl}
\hline Ano & \multicolumn{2}{c}{ Produção } \\
\hline 1919 & 5.396 & hectolitros \\
1920 & 17.878 & hectolitros \\
1921 & 27.965 & hectolitros \\
1922 & 27.020 & hectolitros \\
1923 & 61.075 & hectolitros \\
1924 & 77.548 & hectolitros \\
1925 & 84.595 & hectolitros \\
1926 & 120.417 & hectolitros \\
\hline
\end{tabular}

Marabá mantém-se de tal forma diante da decadência geral, inclusive aproveitando-se desta para a atração de recursos humanos, que em 1922 o município de São João do Araguaia, do qual fora desmembrado, é extinto e incorporado ao município de Marabá, cuja sede, em 1923, é elevada a cidade.

\section{A Frente Extrativista da Castanha}

Toda a infraestrutura que havia sido montada na época da borracha (1898-1919) é transferi da para a exploração da castanha, de caráter menos espetacular, o que foi possível dado o fato de tratar-se de atividade econômica fundamentalmente do mesmo tipo. Por isso mesmo, não consideramos que se inaugure efetivamente um novo período, mas sim que após um momento de crise realizam-se ajustes, importantes sem dúvida, que inauguram como que um novo subperíodo ou fase dentro do mesmo período, mantidas no essencial as mesmas relações de trabalho. É nesse sentido que a Marabá da borracha já é, em grande parte, contemporânea da Marabá de hoje.

Consideramos que dentro de um mesmo grande período na história da região, caracterizada por uma relação fundamentalmente inalterada entre o homem e a natureza, poderemos distinguir fases sempre que houver ajustes importantes que digam respeito diretamente a essa relação, como é aqui o caso; ou, então, quando se realizam transformações fundamentais na organização do trabalho através da qual se dá essa relação, o que também ocorreu em outros momentos, como veremos adiante.

Já se viu que a exploração da castanha se dava anteriormente. No baixo Tocantins, aparentemente, intensificou-se a partir do início do século 
XIX, a princípio em parte tendo Como finalidade a alimentação de porcos e aves na área de Belém e Cametá.

No final do século, até a descoberta dos cauchais do Itacaíúnas, a atenção maior voltava-se para a castanha; apesar de seu valor não se comparar com o da borracha, então explorada em boa parte da Amazônia. Mesmo no baixo Tocantins, porém, segundo MOURA (p. 111), só se exploravam os castanhais até 2 ou 3 quilômetros do rio, e sobretudo na margem esquerda.

Apesar disso, na safra de 1896-97 o Pará exportou 70.758 hectolitros de castanha, sendo pouco menos da metade para os Estados Unidos e o restante para a Europa, especialmente Inglaterra (SANTA ROSA, p. 56). MOURA (p. 112) cita como utilizações locais da castanha na época: a amêndoa em confeitos e doces, o leite para cozido de carnes c peixes e na mistura de certas frutas ácidas (cupuaçu, taperebá ou cajá, etc.), e o óleo para a fabricação de sabonetes, na iluminação e como condimento culinário.

\section{COUDREAU encontra próximo a Mocajuba diversos batelões que:}

....s'en vont à la 'safra' (cueillette) de la 'castanha' ou noix du Brésil, la principale production du Tocantins Paraense, - on peut même dire son unique production, son unique moyen d'existence, de même que le caoutchouc constitue l'alpha et l'oméga de la richesse de tant d'autres rivières Amazoniennes (1897, p. 2).

É o mês de janeiro, e ele continua encontrando diversas canoas que se vão à castanha, numa ocasião que hoje já seria considerada um pouco tarde. E à margem mesma do rio, divisa diversas barracas de castanheiro. Arumateua não é senão

... une agglomération d'une quarantaine de baraques, de castanheiros au milieu desquelles triomphent, modestement, quelque trois baraques plus grandes et plus hautes, qui sont des maisons de commerce. De ces trois maisons de commerce, une seule peut véritablemente se dire d' Arumatheua, ...; les propriétaires des deux autres, ... ne passent ici qu'une partie de l'année, l'époque de la récolte, et habitent le reste du temps leurs établissement principal, le premier à Baião, le second à Cametá.

La quantité totale de castanha exportée par Arumatheua peut s'éleveren moyenne à 30000 hectolitres. Le prix de l'hectolitre de castanha à Pará variant de 20 a 30 milreis, c'est une production de
600000 à 900000 francs par an que représente annuellement l'agglomération de paillotes que a nom Arumatheua.

Ce total n'est point sans étonner quand on considère l'aspect de misère insurmontable mais résignée sous lequel se présentent les quelques vingt-cinq ou trente baraques trop petites où le petit peuple des castanheiros d'Arumatheua oublie, dit-on, le dimanche, son excès de misère dans quelque excès de cachaça (1897, pp. 9/10).

E vai encontrando outras aglomerações, menores, de barracas de castanheiros. Todavia, informa-nos que a safra não dura mais de quinze dias (1897, p. 49), o que é bem menos do que posteriormente, e parece indicar que a castanha só era colhida por ocasião do auge do grosso.

A descoberta dos cauchais do Itacaiúnas reduzirá a atenção dedicada à castanha. A queda posterior dos preços da borracha trará em sua esteira uma onda de decadência, seguida do ressurgimento da extração da castanha; especialmente, agora, no médio Tocantins, onde uma elite local de comerciantes manobrou habilmente, evitando o aparentemente inevitável. Assim fazendo, a relação se inverte, e a borracha terá preparado o caminho para a castanha, realizando, em condições de boom, uma acumulação que permite, a seguir, a exploração da castanha em um nível que provavelmente de outra maneira não seria possível. Marabá será o centro dessa produção, em detrimento, particularmente, do baixo Tocantins. No início da década de 20 já estará produzindo muito mais do que Arumateua na época em que por lá passou COUDREAU ${ }^{8}$.

$$
* * *
$$

Com a queda da borracha, a Amazônia toda caíra num período de depressão. Sua população, que de 1872 a 1920 passara de 332.847 a 1.439.052, em 1940 ainda seria de 1.462.420, com taxa de crescimento inferior ao crescimento vegetativo, e que portanto caracteriza uma região de repulsão (DIAS, 1969, p. 15). Só depois de 1940 iniciar-se-ia uma lenta recuperação.

No entanto, essa estagnação não foi uniforme em toda a imensa região. Nessa época pós-borracha, em diversas áreas da Amazônia buscou-

${ }^{8}$ BUARQUE (p. 10) em sua viagem de 1914 caracterizará Arumateua como “... logar muito esquisito...", com apenas 25 habitantes, que já fora muito rico antes da queda do caucho. Mais tarde desaparecerá de todo. 
se produtos de exportação que minorassem os efeitos da crise crônica. DIAS cita, além da castanha, a sorva, a balata, a coquirana e as madeiras (1969, p. 16). Todavia, não há dúvida de que a exploração da castanha, concentrada particularmente no médio Tocantins, foi a que encontrou o maior sucesso, transformando-se no principal produto de exportação do Pará e tornando Marabá o segundo município do Estado (RODRIGUES, p. 123).

A prosperidade relativa de Marabá, portanto, vinculou-se ao grande período de involução da Amazônia e à castanha. Terminando esse período, terá que lutar para manter a sua posição.

$$
* * *
$$

A castanha. A castanheira, classificada por Humboldt e Bompland como fazendo parte da família das Lecythidaceas, gênero Bertholletia, apresentando as espécies excelsa e nobilis (PENNA FRANCA e outros, p. 187), é uma árvore de grande porte, uma das maiores da Bacia Amazônica. Atinge frequentemente a altura de 50 metros e diâmetro superior a 2 metros. Encontra-se espalhada por toda a Bacia Amazônica, desde as fronteiras do Peru e da Bolívia até as proximidades do litoral do Atlântico (PANDOLFO, p. 1).

Em geral busca os terrenos mais elevados e de características argilosas e argilico-silicosas (PENNA FRANCA e outros, p. 187).

Costuma-se encontrar as castanheiras de modo gregário, em reuniões homogêneas - os castanhais nativos, o que facilita a sua exploração.

O fruto da castanheira, denominado ouriço, mede 8 a 15 centímetros de diâmetro, e é revestido por uma casca espessa, dura e lenhosa.

No interior do ouriço encontram-se de 15 a 25 sementes, que constituem as castanhas, as quais podem variar de 30 a 70 milímetros de comprimento. Possuem casca rugosa e irregular, e uma película fina que adere à polpa da castanha. São classificadas nos tipos miúda, média (pequena e grande) e graúda. As castanhas do Tocantins são em geral do tipo média grande (50 a $55 \mathrm{~mm}$ ) (RODRIGUES, Hildebrando, p. 20).

Segundo PENNA FRANCA e outros (p. 188), é rica em lipídeos (66 a $69 \%$ ) e proteínas (14 a 16\%), possui um teor de sais minerais de 3,5 a
4,5\% e uma concentração de cálcio de 0,11 a $0,24 \%$ do peso úmido da castanha comercial. É considerada de alto valor nutritivo.

A safra da castanha, ocasião em que os ouriços caem ao chão, onde serão coletados (oferecendo, por sinal, grande perigo aos apanhadores, dada a altura da queda), vai aproximadamente de dezembro até junho. De dezembro a março, os ouriços caem em maior quantidade, no que se denomina castanha de grosso; no resto do tempo, a queda de ouriços é bem menor (castanha de cata).

A ocasião da safra coincide com o inverno, o tempo das chuvas, que contribuem para a queda das castanhas; ao contrário da seringueira, que sendo árvore de várzea só pode ser trabalhada quando as águas baixam. Isso facilita o transporte da castanha por via fluvial nas várias etapas de comercialização, pois os igarapés enchem e os trechos mais perigosos do Tocantins devido à existência de pedras e corredeiras tornam-se mais facilmente transitáveis do que durante o verão. Em contrapartida, o trabalho no tempo das águas aumenta o risco da malária.

Existem áreas da Amazônia onde a população ainda se divide entre a exploração da borracha e da castanha, o que é possível dado o fato da safra de uma coincidir com a.entressafra da outra. Todavia, no médio Tocantins paraense isso não ocorreu; mesmo porque o caucho, como vimos; ao contrário da seringueira, costumava ser derrubado, o que reduziu as suas reservas.

Na região de Marabá, os esforços se concentraram na castanha, e a zona do Itacaiúnas tornou-se a maior produtora; responsável, até hoje, por bem mais da metade da produção geral do Estado, que é, por sua vez, o maior produtor. No ano de 1967, a produção geral do país, englobando Rondônia, Acre, Amazonas, Roraima, Pará, Amapá e Mato Grosso, foi de 34.164 toneladas. Desse total, o Pará registrou 18.868 toneladas, das quais 16.577 vieram da zona do Itacaiúnas (ETEA, 1968, pp. 3 a 18). Em toda a grande região produtora, o segundo lugar era ocupado pela zona do Alto Purus, no Acre, com apenas 4.000 toneladas (id., p. 17). Em 1965, o segundo lugar coubera à zona do Baixo Amazonas, no Pará, também muito menor, e que depois caiu bastante. De uma maneira geral, os dados parecem indicar um caráter um tanto acidental assumido pela exploração da castanha em outras zonas. 
Segundo ANDRADE: "As áreas de maior incidência de castanhas estão localizadas na porção meridional da Região Norte, nos médios cursos dos rios Tocantins, Tapajós, Xingu e Madeira e na margem esquerda do rio Amazonas, em menor escala, na área drenada pelos rios Jari, Paru e Trombetas. Em alguns pontos, sobretudo no médio Tocantins, ela aparece de forma tão abundante que forma verdadeiros castanhais" (p.44).

Assim, na região de Marabá os castanhais são considerados extremamente ricos. Os melhores encontram-se entre o Tocantins e o Itacaiúnas, ao sul de Marabá, junto aos afluentes da margem direita do Itacaiúnas, como o Vermelho, o Soror6 e o Sororozinho, nos atuais municípios de Marabá e São João do Araguaia. Estendem-se, porém, até Conceição, e os há também na margem esquerda do Itacaiúnas, para os lados de Itupiranga, Jacundá e Tucuruí, e na direção do Xingu; embora, ao que se saiba, mais fracos. A produtividade dos castanhais varia muito, e por isso o tamanho do castanhal, assim entendida uma porção de terras com razoável quantidade de castanheiras, não é boa medida de seu valor. Uma légua quadrada de castanhal pode variar em produtividade de cerca de 700 a 3.000 hectolitros por safra. Também a maior ou menor distância dos centros onde é concentrada a castanha para envio a Belém, bem como a existência ou não de vias de penetração, influem no valor dos castanhais.

A produção varia bastante de safra para safra, sujeita a fatores naturais incontroláveis e mesmo pouco conhecidos na região. Eis um quadro das exportações do município de Marabá nos últimos anos:

\section{Quadro V}

\begin{tabular}{cc}
\hline Ano & Quantidade (hl) \\
\hline 1955 & 157.100 \\
1956 & 62.105 \\
1957 & 212.745 \\
1958 & 191.064 \\
1959 & 77.226 \\
1960 & 161.890 \\
1961 & 195.484 \\
1962 & 180.672 \\
1963 & 160.401 \\
1964 & 148.953 \\
1965 & 179.046 \\
1966 & 204.534
\end{tabular}

\begin{tabular}{cc}
1967 & 230.528 \\
1968 & 250.857 \\
1969 & 197.300 \\
\hline Fontes: Agência de Estatística de Marabá e Coletoria Estadual.
\end{tabular}

Fontes: Agência de Estatística de Marabá e Coletoria Estadual.

Estas variações sempre trazem preocupações aos produtores. Apesar delas, no entanto, dentro de certos limites, exatamente porque há um controle natural, pois os castanhais são exclusivamente nativos, não ocorrem superproduções do gênero das do café, por exemplo.

O Brasil possui, praticamente, o monopólio mundial da castanha-dopará, pais mesmo o que não é produzido aqui vem da área amazônica da Bolívia e do Peru, e é em geral também comercializado através de Belém. O mesmo ocorre, internamente, com a castanha vinda do Norte de Goiás e de Mato Grosso, que é computada como paraense.

\section{A Primeira Fase da Frente Extrativista da Castanha}

Relações sociais. Nos seus primórdios, o sistema básico de relações sociais envolvido na exploração da castanha prosseguiu na mesma linha seguida anteriormente pela borracha nessa região. Os castanhais eram livres. Os indivíduos que desejassem sair à cata da castanha eram aviados pelos comerciantes, entre os quais, desde cedo, destacaram-se, ao lado dos nacionais, os de origem sírio-libanesa. Os comerciantes de Marabá, por sua vez, eram financiados e abastecidos pelos comerciantes e exportadores de Belém. Esse sistema predominará durante toda a década de vinte. Só com o seu declínio é que se darão modificações importantes nas formas de relacionamento engendradas na fase da borracha.

Em geral, os produtores diretos, para serem aviados, eram obrigados a vender antecipadamente aos comerciantes de Marabá o produto da coleta. Esses indivíduos, os castanheiros, eram oriundos de outras áreas; especialmente, com a diminuição do fluxo mais longo especificamente nordestino da fase da borracha, do Norte de Goiás, Maranhão e, com a sua decadência, também do baixo Tocantins. A grande maioria não se fixava em Marabá, realizando migrações sazonais por ocasião da safra.

Como, portanto, por um lado não se tratava de uma população fixa, sem alternativas de deslocamento porém protegida por um padrão tradicional de relacionamento e solidariedade; e como, por outro lado, as relações de trabalho implicavam um sistema de financiamento a prazo 
relativamente certo, desde cedo a coerção física aberta se instaura como método comum de cobrança de dívidas e, também, de burla generalizada. A violência, juntamente com uma orientação aventureira e especulativa, irá permear todas as relações; o que perdurará por muito tempo. Especialmente enquanto se mantiver o binômio explosivo de mão-de-obra não-fixa mas com um alto grau de isolamento da área no que diz respeito ao controle externo efetivo daquilo que se passa nas relações estabeleci das no seu interior.

Transporte. O transporte da castanha pelo Tocantins, tal como anteriormente o da borracha, realizava-se em geral por conta dos comerciantes de Marabá, pelo menos até Alcobaça (a qual, após 1943, ao ser desmembrada de Baião, passará a denominar-se Tucuruí, que é como a trataremos a partir de agora para simplificar).

Inicialmente, a castanha era transportada em grandes batelões em geral com mais de vinte barqueiros, de Marabá a Tucuruí (Alcobaça), numa distância de pouco mais de 200 quilômetros que se levava cerca de um mês para cobrir. Trata-se de navegação penosa, apenas facilitada em parte pelo inverno. É especialmente difícil entre Jatobal e Tucuruí, onde se encontram diversas corredeiras, das quais a mais notória é a de Itaboca, numa extensão de 12 quilômetros. Nos trechos piores, especialmente no retorno a Marabá, subindo o rio, era-se obrigado a descarregar os batelões e levar as mercadorias por terra.

No entanto, essa navegação foi facilitada, ou pelo menos tornada mais rápida, pelo fato de o início da exploração mais intensa da castanha a partir de 1920 coincidir aproximadamente com o aparecimento no Tocantins dos motores, embarcações pequenas, com 15 a 20. metros de comprimento e equipadas com motores diesel de 40 a $120 \mathrm{hp}$. Seu uso vaise tornando mais generalizado a partir de 1923, e até hoje são utilizados. Desde então, os batelões vão sendo relegados para o transporte nos igarapés, donde serão desalojados pelos penta, que são canoas com motor de popa.

PATERNOSTRO (p. 81), indicando com justeza uma relação entre o progresso técnico e a oligopolização nas relações com o exterior, observa, já na década de trinta:
Os arrendatários e os 'aviadores' utilizaram-se dos meios de transporte modernos (O.G.V.: barcos a vapor e a motor) para 'isolar' na mata os apanhadores de castanha, extinguiram a especulação da época dos barcos a remo, nos quais os párias transportavam os produtos silvestres para vendê-los nas vilas.

De Tucuruí (Alcobaça) para Belém, onde à castanha era vendida de início em leilão e depois de 1929 através de corretores (Hildebrando RODRIGUES), numa distância de cerca de 300 quilômetros, a castanha é transportada sem maiores dificuldades em embarcações de maior calado, denominadas gaiolas, cujo trajeto foi prolongado de Nazaré dos Patos em 1931 (PATERNOSTRO, p. 87). No início da década de 60, a viagem, em navio do SNAPP, levava 36 horas (LARAIA e MATIA, p. 51). A viagem em sentido contrário, subindo o rio, era sempre mais demorada.

Tucuruí tornou-se, portanto, muito importante enquanto ponto de baldeação da navegação entre Belém e o médio Tocantins. Lá foram construídos armazéns para a castanha; e é lá, também, que as mercadorias vindas de Belém para o abastecimento de Marabá e de ampla área para a qual passou a cumprir função redistribuidora (que chega a atingir até Porto Nacional, o antigo Porto Real e Imperial) aguardavam transporte.

É ainda nessa década que é retomada a construção da Estrada de Ferro do Tocantins. A história dessa estrada de ferro, dado que a construção de uma ferrovia foi até há pouco tempo no Brasil em geral o símbolo e o marco da prosperidade de uma economia de exportação, bem assinala as vicissitudes da economia amazônica e, particularmente, as da prosperidade apenas relativa advinda da castanha.

O projeto inicial da estrada falava em alcançar-se São Vicente do Araguaia (atual Araguatins) ou Boa Vista (atual Tocantinópolis), em Goiás (PATERNOSTRO, p. 87). O projeto finalmente posto em execução data da última e eufórica década do século passado, quando começavam a surgir os indícios de caucho na área e aumentava o interesse na ligação com áreas mais ao sul por razões de abastecimento e de comunicação. Pretendia-se que a estrada tivesse uma extensão de 180 quilômetros, indo de Tucuruí (Alcobaça) a Praia da Rainha, a cerca de 60 quilômetros de onde veio a se situar Marabá (OLIVE1RA, p. 8).

É por essa época que o Governo do Pará patrocina as expedições de MOURA, COUDREAU e BUSCALIONE, e é o próprio COUDREAU que 
se refere diversas vezes ao projeto da estrada e, mesmo, à passagem por um acampamento de trabalhadores da mesma (1897, pp. 1/15): Todavia, já aí parece ter havido uma interrupção ou adiamento nos trabalhos, os quais só se iniciam de fato em 1905, quando a nova exploração do caucho deve ter concretizado a sua viabilidade econômica. Em 1908 foram inaugurados os 43 quilômetros iniciais.

A decadência da exploração da borracha traz nova interrupção. Só por volta de 1927 é retomada a construção, o que é indício de como nessa data já se reafirmara o prestígio da área, um dos poucos focos de maior atividade econômica no interior do Estado empobrecido. Todavia, não se trata mais de um grande boom, como o da borracha, e a estrada se arrasta. Em 1935 havia 87 quilômetros de linha, percorridos por um trem duas vezes por mês (PATERNOSTRO). Somente em 1944-46 alcançará a localidade de Jatobal, numa distância de 117 quilômetros de Tucuruí com bitola de 1 metro. Aí estacionará, transformando-se, tal como outras ferrovias da Amazônia, em mero expediente para contornar os trechos encachoeirados dos rios.

$$
* * *
$$

Em 1927 Marabá torna-se sede de comarca, e em 1929 instala-se uma usina a vapor, à base de lenha, para iluminação da cidade. Apesar de tudo, no entanto, a cidade guarda muito do seu caráter provisório, dado o fato do predomínio praticamente absoluto de uma atividade sazonal não permitir que boa parte da população se fixe em definitivo. Quase todo abastecimento continua vindo de fora.

Em 1935, a cidade terá cerca de 3 mil habitantes, dos quais metade com residência mais ou menos estável, apesar de $75 \%$ das 460 habitações serem simples palhoças (PATERNOSTRO, p. 107)

\section{MARABÁ DA CASTANHA E DO DIAMANTE}

Na década de 50 um padre francês escreveria um livro sobre Marabá: Marabá, Cidade do Diamante e da Castanha (LAGENEST). O título, efetivamente, descrevia de modo sucinto toda uma fase da história das frentes na região, bem como o papel central desempenhado por Marabá enquanto centro urbano. $\mathrm{O}$ que o autor não pôde perceber é que o que ele descrevia já estava em seu ocaso. Na verdade, como veremos, o auge da Marabá da exploração da castanha e do diamante combinados já se dera.

De 1920 a 1925 dominou na região de Marabá de modo praticamente absoluto o sistema dos castanhais livres, numa quase continuidade, do ponto de vista sociológico e ao nível da produção, com o sistema de exploração da borracha nessa região. Os castanhais, por essa época, iniciavam-se já nos arrabaldes da cidade, e é de se imaginar que de início ainda não fossem explorados castanhais muito afastados. Com isso, o problema do abastecimento dos castanheiros era relativamente simples. À medida que se avançava mais para o interior, apoiado, inclusive, na generalização das inovações nos meios de transporte a que se refere PATERNOSTRO (ver capítulo anterior), cujo controle, pelo investimento maior que exigiam, não podia se distribuir igualmente, é que surgia a presença maior do barracão. Tratava-se de uma espécie de armazém dentro da própria mata, e a ele tinham de recorrer os castanheiros que trabalhavam na, zona em torno, com margem cada vez menor para alternativas à proporção que a distância da beira e de Marabá aumentava. Isso caracteriza uma situação de monopólio local. O caráter fechado da estrutura do comércio ajudaria a abrir o caminho para o estreitamento no controle da produção. Ainda por cima, as Davas exigências em geral da exploração ampliada, com a necessidade de abertura de caminhos, a distribuição das colocações dos castanheiros, o transporte, certamente contribuíram para minar o sistema dos castanhais livres, e a justificar a sua substituição em nome da organização da produção e de uma maior produtividade do trabalho. Fato semelhante deve ter ocorrido em outras áreas ainda na época da borracha, o que não teria chegado a se dar em Marabá basicamente dado o início tardio da sua exploração e sua importância relativamente secundária em comparação com outras áreas produtoras de borracha. Isso, 
aliás, deve ter contribuído para o crescimento inicial de Marabá, para onde a massa de produtores em geral tinha de se, dirigir diretamente.

Todavia, não foi só ao nível da economia e das relações sociais de caráter econômico que surgiram razões para a transformação do sistema. $\mathrm{O}$ mesmo ocorreu ao nível da política. A área havia de integrar-se no esquema da política dos coronéis da República Velha. Isso era fundamental em relação às áreas novas do ponto de vista da política dominante, pois caso contrário poderia surgir um subsistema relativamente independente e incontrolado. E seria especialmente ameaçador, após a queda da borracha, se justamente uma das áreas agora mais importantes do Estado do Pará conseguisse manter-se à margem. A plena incorporação da área exigia a formação de Uma estrutura de lideranças definidas, comprometidas com o sistema dominante, e que prolongassem no nível local a escala de hierarquias em que se apoiava. A permanência de um sistema de exploração livre era incompatível com tal exigência.

A tradicionalização dar-se-ia através do sistema de arrendamento de castanhais a título precário por parte do Governo estadual, com que se combinaram os interesses de uma oligarquia local nascente com as necessidades do sistema político dominante. Assim se inaugura a segunda fase da frente extrativista da castanha.

O novo sistema começou a surgir a partir de 1925. Aparentemente, foi uma reinvidicação do chefe político local de então - Teodoro de Mendonça - aos seus correligionários no Governo do Estado de uma arma para favorecer os elementos da situação e controlar o comportamento político. Como os arrendamentos seriam provisórios - em geral por uma safra - podiam, a juízo do chefe político, deixar de serem renovados. Esperava-se que os aquinhoados, em troca do prestigio e do poder advindos, fossem capazes de retribuir politicamente a graça recebida. Poderiam ou não já possuir anteriormente alguma fonte de poder. Muitas vezes aqueles que eram alçados de quase nada através do mecanismo do arrendamento eram os mais suscetíveis a um compromisso de fidelidade irrestrita. Certamente, pouco tinham de uma classe dominante tradicional. Tratava-se quase que da criação de uma oligarquia, tendo por esteio a camada de comerciantes; ou pelo menos da efetiva consolidação e institucionalização de uma oligarquia nascente sem a qual o sistema não se reconheceria.
O sistema em Marabá chegou tarde, quando a República Velha já se aproximava do seu crepúsculo. E até 1930 ainda não chegara a predominar, estando ainda na fase inicial de implantação.

Todavia, nisto como em muito mais, a Revolução de 30, ao invés de anular a prática antiga, adotou-a. Tratava-se de arma política por demais valiosa para ser desprezada, especialmente por homens realistas como o tenente-interventor, e depois Governador do Pará, Joaquim Magalhães Barata, figura que dominaria a política paraense por muitos anos. A partir daí, o sistema de arrendamento avançou rapidamente, passando a predominar. No entanto, manteve-se uma certa coexistência, que fazia parte da doutrina do novo sistema. entre castanhais arrendados e os chamados castanhais do município, onde qualquer individuo, mediante matrícula nas prefeituras, poderia retirar castanha. Teoricamente, esses castanhais eram inarrendáveis; eram do povo. Entretanto, a longo prazo a tendência foi serem, primeiro controlados indiretamente através do comércio, e depois tomados de início pelos arrendatários de castanhal e mais tarde também pelos pecuaristas e agricultores. Produziram, no entanto, como veremos, consequências que perduraram.

Com o Estado Novo, a legislação é consolidada, através do DecretoLei $\mathrm{n}^{\circ} 1$, de 3.143 , de $1^{\circ}$ de novembro de 1938 , que "Regulamenta o Serviço de Arrendamento de Terras para Exploração de Produtos Nativos", aplicável também à extração de outros produtos em todo o Estado. Nesse decreto nota-se, ao lado da intenção estritamente política, a preocupação com certa racionalização da produção, que era de interesse do Governo, agora mais independente em face do poder privado, embora sem romper em geral os laços de lealdade política.

$\mathrm{O}$ decreto estipulava que o loteamento fosse feito a partir de um curso d'água, que portanto tomaria toda a frente, com o que se facilitavam as comunicações. Os lotes não poderiam exceder uma légua quadrada ${ }^{1}$. Os arrendatários seriam obrigados a "promover a limpeza rigorosa dos igarapés e grotões, estradas e caminhos". Cada arrendatário deveria manter um "roçado de 100 metros quadrados para a plantação de cereais". Em cada lote dever-se-ia plantar duzentos castanheiros e construir sólidos barracões.

\footnotetext{
${ }^{1}$ A légua corresponde a $6 \mathrm{~km}$. e, portanto, a légua quadrada a $36 \mathrm{~km}^{2}$.
} 
O contrato seria inicialmente por uma safra, e depois por cinco anos, podendo ser refeito caso não houvesse outro, pretendente.

Na prática, pouco foi respeitado das exigências do decreto. A légua quadrada era esticada para duas ou mais léguas, e um mesmo individuo mantinha sob seu controle diversos castanhais através do expediente de arrendá-los em nome de parentes. A atividade de exploração da castanha manteve-se altamente predatória, sem um esforço de investimento maior e de melhoria das condições de trabalho. Muitos entre os maiores arrendatários de castanhal tendiam a aplicar os seus lucros fora da região, em geral em Belém, onde não poucos passaram a residir com as famílias, só se deslocando para Marabá por ocasião da safra.

Aparentemente, em parte a exacerbação do caráter predatório deveuse à própria incerteza da posse: não se tendo certeza sobre a manutenção do arrendamento, retirava-se tudo o que se pudesse, nada se colocando em troca. O sistema de arrendamento apenas a prazo, no entanto, deve ter dificultado, até certo ponto, a concentração da posse da terra além de certos limites, É lógico que os produtores diretos foram em grande parte expropriados, porém os arrendatários de castanhal mantinham-se em mais de uma centena, e apesar de alguns serem bastante ricos, a maioria, em termos de uma estratificação social, constituiria uma espécie de classe média. $\mathrm{O}$ poder maior mantinha-se nas mãos dos comerciantesfinanciadores, dos quais quase todos dependiam; e os maiores arrendatários eram também comerciantes. Talvez do ponto de vista político esse espraiamento maior do poder, nas circunstâncias de então, permitisse um controle maior sobre uma situação que resistia e apresentava dificuldades no seu manejo através dos mecanismos tradicionais, dadas suas características insólitas de mobilidade da mão-de-obra ${ }^{2}$.

2 "Surpreendemos em Marabá, em pleno 1938, o mesmo tráfico escandaloso que subsistiu para a borracha amazônica. Apenas a quarta parte dos castanhais é propriedade privada. Todos os demais pertencem ao Estado ou Município, que os arrendam mediante requerimento, pelo prazo de um ano. Esse regime inconveniente mantém-se há muitos anos. Os castanhais são invadidos anualmente pela turba de castanheiros. Mas continuam inteiramente virgens de benfeitorias. Não há caminhos, nem estradas, nem ranchos, nem moradores...

A castanha é hoje o sustentáculo da máquina administrativa do Pará. Em torno dela giram as leis, os regulamentos, os negócios e as negociatas.
Os castanheiras, agora, já se internavam muito na mata; em geral a ponto de tornar impraticável o contato com um centro urbano durante os meses de trabalho, e mesmo com pouquíssimos outros contatos humanos. Podiam situar-se em colocações que distassem muitos dias a pé de Marabá. Eram aviados antes de partirem por seus patrões, que quando arrendatários eram também empresários da produção. O dinheiro que restava do que lhes havia sido adiantado era invariavelmente gasto nas farras, numa compensação antecipada dos meses de isolamento vir. Alguns levavam para a mata mulheres da vida, que lhes prestavam então, não só serviços sexuais, mas serviços domésticos em geral, sendo motivo, por vezes, de violentas disputas nos pequenos grupos de castanheiros.

Os castanheiros tentavam manter-se durante a safra o mais autossuficientes que fosse possível, para evitar as dividas nos barracões do castanhal. Alimentavam-se em boa parte de caça, da própria castanha e do seu leite, do açaí, do cupuaçu etc. Mesmo assim não podiam deixar de recorrer ao barracão em busca de munição, querosene, sal, açúcar, café,

O sistema de arrendamento dos castanhais, a que nos referimos, tem dado excelentes resultados em todas as manobras políticas, porém não é o mais indicado para um país que precisa mobilizar suas energias e ordenar sua economia. Explica-se facilmente que um arrendatário não procure fazer benfeitorias e radicar moradores em terrenos que na próxima safra serão de outro dono...

Tomassem-nos hoje o mercado da castanha e não ficaria em Marabá vestígio da extraordinária movimentação do passado. A grandeza dessa atividade extrativa, que, desde a crise da borracha, sustenta o brilho da civilização paraense, não construiu ainda um só marco no Tocantins que perpetuasse sua existência...

Apenas o grande Palácio da Prefeitura, em construção, atesta um certo movimento, orientado para a ocupação definitiva do solo (O.G.V.: é ainda hoje a sede da prefeitura e é na mesma direção, afastado do pontal onde se deu a fundação de Marabá, que nos anos seguintes se desenvolveu a parte melhor da cidade). A cidade arrasada pela enchente de 1926 ressurgiu imprevidentemente no mesmo local, com seus caracteres próprios, ditados por fatores humanos de ordem econômica e geográfica.

A teimosa localização de Marabá não se prende a fatos muito complexos nem se explica tampouco por escolhas anônimas e inconscientes. Foram as necessidades da atividade econômica, criadas pela exploração dos castanhais, que reconduziram o agrupamento humano ao mesmo local desfavorável e inseguro...

A necessidade de dominar os dois rios explica-se facilmente, dado o regime de financiamento da colheita da castanha. Arrendatários, castanheiras e embarcadiços, ao início da safra, já estão empenhados por grandes dívidas aos comerciantes..

Com tal sistema de trabalho, compreende-se facilmente a necessidade do comércio instalarse em local que lhe permitisse exercer atenta fiscalização sobre as atividades de seus 'financiados' nos dois rios" (OLIVEIRA, pp. 35/39). 
fumo, farinha etc.; a não ser que ainda estivessem muito próximos a Marabá, o que cada vez mais deixava de ser a regra geral.

Não é preciso dizer que as condições de trabalho eram as piores possíveis, sujeitos à chuva, às doenças, aos animais e mesmo a choques com grupos indígenas ${ }^{3}$. Seu abrigo era o mais tosco que se possa imaginar: uma simples cobertura inclinada de palha sobre estacas onde era amarrada a rede.

Um bom castanheiro podia apanhar cerca de 2 hectolitros de castanha por $\mathrm{dia}^{4}$. O trabalho consiste na coleta simples do chão seguida da abertura do ouriço para retirada das castanhas. Periodicamente, o produto da coleta era transportado a determinados pontos, geralmente no mesmo local do barracão, onde era entregue e medido. A medida era feita em recipientes de volume correspondente a 1 hectolitro. Ocorre que oficialmente, no castanhal, de fato o hectolitro deveria corresponder a 1,08 hl. Fazia-se esse acréscimo de $8 \%$, por conta das perdas prováveis até a entrega em Belém, tendo em vista os transbordos, desgastes, quedas, apodrecimentos etc. Assim, deveria sobrar um pouco de castanha acima do nível do recipiente. Corno, no entanto, o cálculo desse acréscimo, a chamada cabeça do hectolitro, era feito a olho pelo encarregado, era fonte invariável de fraudes, praticamente institucionalizadas, a cabeça do hectolitro chegando a alcançar até $40 \%$ do hectolitro. Havia, ainda, outros recursos, como o desfiguramento dos recipientes. Como regra geral essas fraudes eram aceitas 'mais ou menos passivamente por medo de represálias.

Com tudo isto, ao descontar-se o aviamento e as dívidas no barracão, reduzia-se bastante a parte da castanha que cabia ao castanheiro, o qual, em geral, vendia a sua parte ao próprio patrão, se já não o tivesse feito antecipadamente. Havia vezes, mesmo, em que nada sobrava, ou, até, em que se ficava devendo. Nesse último caso, o castanheiro ficava trabalhando para o patrão numa espécie de regime de servidão por dívida. A alternativa era a fuga, com o risco de ser apanhado e morto pelos capangas do patrão. Havia casos em que se prometia o perdão da dívida em troca de algum serviço prestado, seguidamente o assassinato, que por vezes era o de um companheiro que havia conseguido acumular um saldo razoável. Afora

\footnotetext{
${ }^{3}$ Ver LARAIA e MATTA.
}

${ }^{4} \mathrm{O}$ hectolitro da castanha bruta corresponde de 50 a $60 \mathrm{~kg}$. esses casos extremos, que no entanto não eram tão raros, a violência se revelava de modo constante nas modalidades de burla que exemplificamos e no atraso quase que sistemático no pagamento do saldo.

No entanto, obviamente, como regra geral alguma coisa se retirava no final da safra. Não era muito, mas não havia alternativas melhores na região ou em torno, e impressionava quando recebido de uma só vez, e tendo-se, mal ou bem, sobrevivido parcialmente a crédito nos meses anteriores. Esse dinheiro, mais uma vez, era frequentemente gasto quase todo nas farras, quando não tomado pela policia sob um pretexto ou outro. Apesar de tudo, constituía uma boa parte do numerário advindo da castanha gasto na própria Marabá, já que os lucros de comerciantes e arrendatários eram em grande parte investidos ou gastos fora.

A “lógica” da espoliação. O regime de violência e espoliação brutal de que eram vítimas os castanheiros em parte tinha sua razão econômica, encarado sob o ponto de vista dos setores dominantes, enquanto técnicas de extorsão de mais-valia absoluta. Prende-se, no que diz respeito à intensidade com que se dava, não só à dificuldade em se oferecer resistência, mas à instabilidade que era uma ameaça para os próprios organizadores da atividade produtiva, seja devido a fatores naturais e ao sistema de arrendamento a prazo, a que já nos referimos, seja devido a sua própria sujeição econômica em outro nível. Os laços que se estabeleceram entre os comerciantes e arrendatários de Marabá e os grupos exportadores de Belém, alguns deles estrangeiros, fizeram com que se transformassem em mais um elo na cadeia de exploração. Por mais que tentassem reduzi-lo, a atividade da castanha implicava um investimento relativamente volumoso, com a manutenção de sua mão-de-obra a crédito, o transporte e a armazenagem do produto e um mínimo de obras no castanhal para facilitar a produção e o escoamento. Isso fez com que fossem obrigados a se deixar financiar por esses grupos, diretamente ou, no caso da maioria menos poderosa, através do próprio comércio de Marabá. Acresce que os grupos de Belém tinham muito mais possibilidade de manipular o mercado, tanto do lado da oferta quanto da procura. Sem falar de seu poder econômico e político e da possibilidade de jogar os grupos marabaenses uns contra os outros.

Em 1935, de acordo com PATERNOSTRO (p. 81), o apanhador de castanha recebia $10 \$ 000$ pelo hectolitro de castanha, o comerciante vendia 
ao exportador por $58 \$ 000$ e este por sua vez vendia para o exterior por $100 \$ 000$.

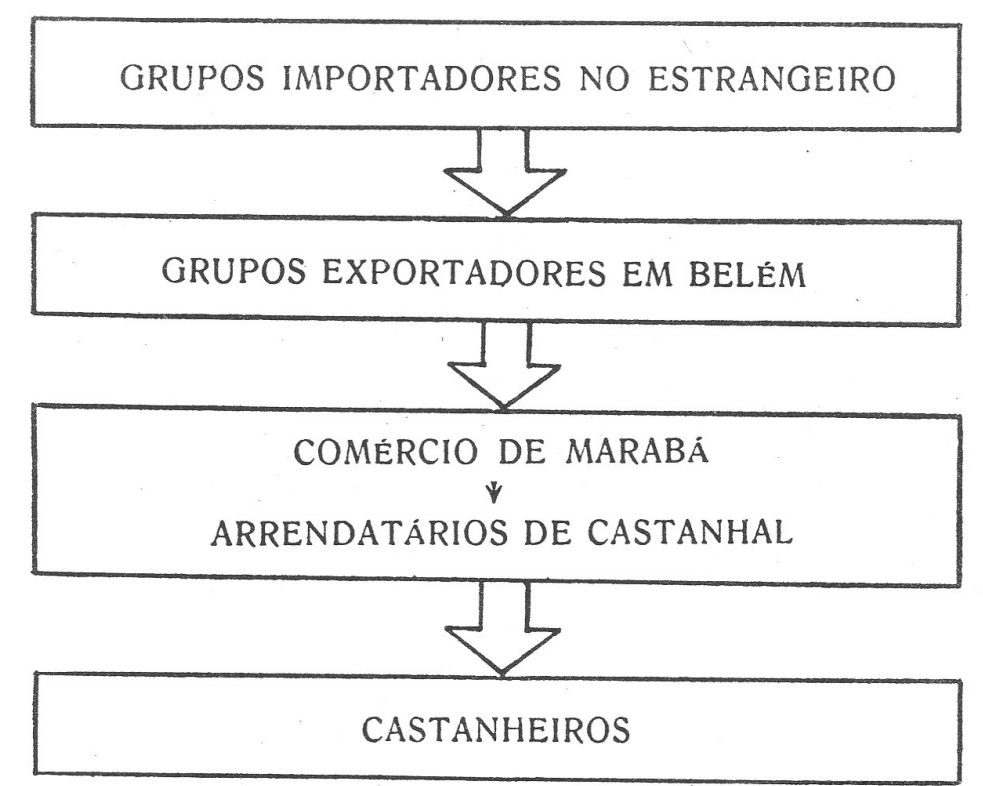

Até a II Guerra Mundial, os maiores mercados encontravam-se na Europa. Eram Inglaterra e Alemanha, sendo o principal porto importador Liverpool, onde se localizavam as maiores organizações importadoras. Em 1935, de uma safra de 24.321 toneladas, 13.540 foram enviadas para a Inglaterra (PATERNOSTRO, p. 81).

Durante a Guerra, os Estados Unidos, que já eram um mercado de importância, tornam-se praticamente o único. Após o final do conflito manterão a primazia, através, especialmente, dos portos de Nova York e Los Angeles, muitas vezes revendendo o produto a outros compradores.

Existem cerca de seis grupos exportadores importantes em Belém. Com o virtual oligopólio que mantinham, já que até recentemente era praticamente insignificante a parte da castanha consumida no mercado nacional, eram capazes de descarregar boa parte dos efeitos das oscilações de preços no mercado internacional em cima dos grupos de Marabá; os quais, então, buscavam se resguardar levando às últimas consequências o processo de extorsão da mais-valia absoluta.

Os grupos de Marabá sem dúvida realizaram esforços de unidade. Teve certa importância a Associação de Castanheiros, e também a Maçonaria, que cumpria importante função na reunião e integração da elite local. Todavia, as rivalidades, quer econômicas, quer políticas, reduziram a eficácia de sua ação no que diz respeito ao seu efeito extralocal. Não era raro arrendatários de castanhal invadirem castanhais de outros, ou comerciantes comprarem castanha que sabiam haver sido retirada clandestinamente de algum castanhal. Em política por vezes chegavam a ocorrer assassinatos.

Obviamente, a importância concreta de Marabá no âmbito estadual resguardava-lhe um lugar de destaque, mas que tinha severos limites, a que não é estranha, no plano nacional, a diminuição do peso político e econômico da Amazônia, que dificultava a reinvidicação bem sucedida de apoio governamental. Marabá, estranhamente, ao mesmo tempo em que vivia em função de um mercado internacional que trouxe às Brazil nuts uma certa celebridade, mantinha-se bastante marginalizada no plano nacional, apesar das divisas, de modo algum desprezíveis, que carreava ${ }^{5}$.

\section{A Atividade Intersticial da Agropecuária}

O tipo ideal de uma economia extrativista implica se ter a imensa maioria dos indivíduos diretamente empenhados nela. Marabá aproximouse bastante disso, a ponto de, tratando-se de uma atividade sazonal, boa parte da população nem sequer se fixar, e ter-se uma grande desproporção entre homens e mulheres; em 1940; por exemplo, 7.839 homens para 4.714 mulheres, sendo de se notar que o censo é realizado na entressafra ${ }^{6}$. Segundo LAGENEST (p. 29), ainda em 1955 somente cerca de uma família em quatro possuía "residência firme" em Marabá.

Todavia, na prática isso não deixaria de sofrer algumas alterações; embora, ainda, dentro do mesmo quadro geral. Obviamente, um certo

${ }^{5}$ Nos últimos anos têm variado aproximadamente entre 9 e 15 milhões de dólares anuais, situando-se entre os vinte principais produtos de nossa pauta de exportações; à frente, por exemplo, em 1968, de mate, pimenta, borracha, ceras vegetais, castanha de caju etc. Ver Anuário Estatístico do Brasil, 1966 e 1969.

${ }^{6}$ Ver IBGE, 1952 
contingente de indivíduos não poderia deixar de se fixar; especialmente no caso daqueles que haviam se deslocado de distâncias maiores, não podendo manter o padrão de migrações sazonais, tal como o faziam, exemplarmente, os habitantes do baixo Tocantins e do Tocantins maranhense. Por outro lado, havia uma tendência, em função do próprio gênero de economia dominado pelo comércio, à concentração urbana em Marabá7. Assim, criava-se um mercado suscetível de sofrer eventualmente um processo de substituição de importações de gêneros primários; ainda mais que as comunicações com as fontes abastecedoras durante o verão tornavam-se precárias. Isso vai-se dando lentamente a partir do final da década de 30.

É assim que, aos poucos, cria-se uma pequena agricultura de beira de rio ou de lago e nas ilhas; ou seja, em território menos cobiçado para outras atividades. Trata-se, basicamente, de uma atividade de subsistência, de caráter marginal, função das dificuldades de pleno emprego constante da mão-de-obra. Mas o seu eventual excedente vai ser vendido nas feiras e no mercado de Marabá (construído na década de 30) ou será comprado para consumo nas matas durante a safra da castanha. É uma produção modesta, que não chegará a substituir ainda, de maneira muito significativa, a importação maciça de gêneros. E isso apesar da produção da castanha não oferecer a mesma abundância de meios de pagamento que tornavam fácil anteriormente a aquisição fora desses bens encarecidos.

Segundo o Recenseamento de 1940, a produção de 1939 foi de 27 toneladas de arroz, 68 toneladas de farinha de mandioca, 21 toneladas de feijão, 1.762 toneladas de mandioca e aipim e 48 toneladas de milho. Havia, também, alguma produção de hortigranjeiros e frutas. Tinha-se, por essa época, 24 estabelecimentos que declararam praticar a agricultura em pequena escala (IBGE, 1952).

A própria prefeitura estimulará em certa medida a instalação desses agricultores por razões de abastecimento, e, possivelmente, para evitar a presença de desocupados. Em 1951 dividirá, em área já invadida, cerca de 1 légua quadrada de terras do município junto à cidade e próximo à antiga localização do Burgo Agrícola, em 174 lotes, constituindo a chamada Colônia Quindangue. Dá-se uma certa concentração desses agricultores,

${ }^{7}$ Mesmo no Recenseamento de 1960 tinha-se que 44,08\% da população era urbana. O Recenseamento de 1940 dava para o distrito de Marabá, que hoje constitui o município, uma população de 4.473 habitantes, sendo 1.500 urbanos, 1.394 suburbanos e 1.579 rurais. também próximo a Marabá e por vezes se dedicando à construção e reparos de barcos e uma série de serviços urbanos ocasionais, no Amapá, bairro que se desenvolve do outro lado do Itacaiúnas. Ainda em 1951, um ano depois da cidade ter registrado no Censo uma população de 4.973 habitantes, com um aumento de $70,6 \%$ em relação ao Censo anterior, instala-se a primeira beneficiadora de arroz, que em 1953 beneficia 343 toneladas de arroz (DIAS, 1958, p. 403).

Por outro lado, a tradição pecuarista nunca chegou a desaparecer de todo. Mesmo porque havia necessidade de algumas centenas de jumentos para o transporte, especialmente nos castanhais. Cria-se, nos próprios castanhais, pequenos pastos artificiais para os jumentos, e aproveita-se para colocar algumas cabeças de gado bovino, para o próprio consumo no castanha!. Todavia, até meados da década de 50, ainda se importará gado bovino para o consumo local. No entanto, é esse próprio consumo local que criará algumas das premissas para o desenvolvimento da pecuária. Assim, o gado que vinha a pé de Goiás e Maranhão, gastando meses, emagrecia muito na viagem, e por isso aparecem modestas invernadas de pasto artificial (por ser zona de floresta) para a engorda do gado ${ }^{8}$. A dificuldade de transporte, os altos preços e o virtual monopólio dos marchantes locais, levam a prefeitura a estimular alguns desses invernistas a se transformarem efetivamente em criadores. É o que ocorre com alguns deles, entre os quais se encontrava o indivíduo que vem a ser o maior criador de gado de Marabá. O Censo de 1940 (IBGE, 1952) registra 19 estabelecimentos que praticavam a agropecuária em pequena escala, 1 a pecuária em pequena escala e 6 em grande escala. Marabá possuía, então, um modesto rebanho bovino de 2.320 cabeças, que em 1950 será, ainda, de 3.110 cabeças (IBGE, 1952 e 1957).

Em 1953 o movimento dos matadouros locais registrava o abate de 1.768 bovinos durante o ano (DIAS, 1958, p. 506).

Assim como no plano nacional, nos interstícios das atividades primárias, tomadas como um todo, e das atividades a elas ligadas, surgia a industrialização, na região de Marabá, nos interstícios da extração vegetal, surgia a produção agropecuária. O seu caráter intersticial não só ajuda a

${ }^{8}$ Diz OLIVEIRA, referindo-se a 1938: "Na mata paraense, abrem se as primeiras clareiras para o preparo de pastagens, só para permitir a engorda do gado sertanejo, até hoje consumido quase que exclusivamente sob a forma de charque" (OLIVEIRA, p. 74). 
esclarecer o caráter da atividade principal, como anuncia um germe, embora não suficiente, de possíveis transformações para o futuro.

\section{A Frente Mineradora}

No entanto, por essa época, atendo-nos a uma perspectiva sincrônica, a atividade que surge como verdadeiramente complementar, e não apenas intersticial, da castanha, é ainda extrativa, e acomoda-se plenamente ao panorama dominante. Como já vimos, com a decadência das minas no Centro-Sul ainda durante a Colônia, aumenta o interesse na ligação com o Norte (caps. 2 e 3), a que não é estranha a busca de novos recursos minerais em escala agora mais reduzida. É assim que surge o que podemos denominar de uma frente mineradora norte-goiana. Frente relativamente secundária, pois reduziu-se a uma mineração superficial, com resultados, no final das contas, relativamente modestos. Isso apesar de surtos localizados, que provocavam booms de curta duração, mas por vezes de consequências locais importantes. É assim que surgiam as famosas corrutelas, à beira do Araguaia e do Tocantins, das quais a mais célebre em anos recentes foi a do Chiqueirão, em Xambioá (Norte de Goiás), na década de 50.

A busca de minérios acaba aproximando essa frente; que tal como as outras possuía o seu tempo específico, de Marabá; por onde, a partir do final da década de 30, ganha interesse maior a exploração de diamantes, sendo os primeiros encontrados em 1939-40. Eram, portanto, inicialmente indivíduos vindos de fora e itinerantes. Todavia, termina por interessar também aos que se deslocavam para a castanha, já que as duas atividades não eram incompatíveis, uma vez que a busca de diamantes no fundo dos rios era realizada no verão, quando as águas baixam. Surgiu, assim, um importante fator de fixação da mão-de-obra na região, que passa a merecer o titulo que lhe foi dado, já um pouco tardiamente, por LAGENEST.

Talvez seja, aliás, a mineração que explique o fato assinalado por LAOENEST (pp. 25 e 21) do aparente aumento relativo ainda na época de seu estudo (1955) da proporção de goianos na população de Marabá, em detrimento de maranhenses e piauienses, o que é sugerido pelo exame comparativo dos óbitos havidos entre os maiores de 15 anos e dos casamentos religiosos:
Quadro VI

\begin{tabular}{ccc}
\hline Procedência & Óbitos & Casamentos \\
\hline Maranhenses & $65 \%$ & $62 \%$ \\
Goianos & $16 \%$ & $21 \%$ \\
Piauienses & $10 \%$ & $8 \%$ \\
\hline
\end{tabular}

A exploração do diamante, a não ser no que diz respeito àqueles que trabalham por conta própria no seco, acaba por fixar-se numa organização que consiste num barco com 6 a 15 homens que descem ao fundo dos rios em escafandros em busca do cascalho. Há um patrão, que fornece a equipagem (canoa, bomba de ar e escafandro) e a alimentação, e fica com 50 a $60 \%$ dos lucros. Isso exige uma certa aplicação de capital, que veio a interessar, muitas vezes, aos próprios comerciantes e arrendatários de castanhal como aplicação de seus lucros, criando outro vínculo entre as duas atividades. Muitas vezes, os pequenos arrendatários de castanhal dedicavam-se pessoalmente à atividade de mineração. Assim, surge, além da oportunidade de fixação da mão-de-obra, uma certa fixação local dos lucros da castanha. Todavia, isso apenas em parte, e por sua vez o diamante é todo exportado, e seguidamente contrabandeado, o que torna pequena a sua contribuição aos cofres públicos locais e praticamente impossível uma avaliação razoável da produção.

Com a II Guerra Mundial, surge o interesse por outra atividade mineradora: a do cristal de rocha, material de importância estratégica. Em função deste e de outros produtos, inclusive, novamente, a borracha, a Amazônia por essa época ganha novo interesse, dada a dificuldade de acesso a outros fornecedores por parte dos norte-americanos. Durante os anos de guerra (esp. 1940-44), a exploração de cristal torna-se, realmente, bastante importante; ainda mais que os mercados importadores de castanha reduziram-se, até 1944, praticamente só aos Estados Unidos. A exploração do cristal de rocha, realizada em terra, ora era livre, ora obedecia também ao sistema de patrão, dada a necessidade de aviamento.

Essas atividades mineradoras aumentam mais um pouco o interesse pela agropecuária, pela necessidade de abastecimento das corrutelas, o que permitirá a alguns indivíduos um início de acumulação nesse setor. E mais, essas próprias corrutelas significam, por vezes, o aparecimento de novos aglomerados ou; então, um novo impulso para os antigos. São João do Araguaia, por exemplo, que em 1880 possuía 285 habitantes (CRUZ), que 
COUDREAU encontra no final do século XIX com 200 habitantes e que pelo Censo de 1940, mais de quarenta anos depois, estava reduzida a 100 habitantes (IBGE, 1952), conhece uma certa movimentação em 1942, com a descoberta de um garimpo. Esses garimpos, no entanto, pelo gênero rudimentar de tecnologia empregado, logo são considerados esgotados, e em geral reduzem-se drasticamente ou mesmo desaparecem, a não ser quando conseguem fazer substituir por uma nova atividade, qual seja a de porto ou, mais tarde, a de comunidade agrícola. É o que veremos adiante no caso de Apinagés.

Com o final do conflito mundial, a atividade mineradora, especialmente do diamante, prossegue, embora lentamente declinante. Até a primeira metade da década de 50, no entanto, ainda guarda bastante importância, enquanto atividade complementar da extração vegetal. Nesse sentido, ela é mais típica nessa segunda fase da frente extrativista da castanha. Hoje é nitidamente decadente, sendo, de certo modo, substituída pela pecuária, enquanto campo de aplicação de capital. Parece haver um retorno à mineração no Norte de Goiás. Segundo LAGENEST (p. 54), em 1955 havia 5 compradores de diamante em Marabá; em 1969 estavam reduzidos a $u m$.

Mantém-se, no entanto, na região, como atividade alternativa em momentos de crise. E eventualmente, em especial nessas ocasiões, exploram-se pequenos garimpos que atraem contingentes populacionais, retirando-os por vezes de outras atividades.

Isso é coerente com uma característica da área que começa a se acentuar na década de 40 , com a fixação maior da população, e que é justamente a do surgimento de atividades secundárias alternativas ou complementares às atividades principais. Quanto a isso, aliás, não se pode deixar de mencionar o comércio de peles, a que poucos se dedicam integralmente, mas que reforça os magros haveres de muitos. A diversificação de atividades, portanto, nesse caso dá-se no próprio plano individual, i.e., o mesmo indivíduo com várias ocupações; em lugar de uma diferenciação ocupacional do grupo devida à ação de forças desenvolvimentistas evidentes que levassem a uma divisão social do trabalho mais intensa.

$$
* * *
$$

Em 1944- 46 termina a construção da Estrada de Ferro do Tocantins, que vai de Tucuruí a jatobal. Em 1948 cria-se, provavelmente em consequência, o município de Itupiranga, com o desmembramento de Marabá dos distritos de Itupiranga e jacundá, onde se encontram três pequenos povoados, exatamente Itupiranga (o antigo Lago Vermelho), Jacundá l' jatobal. Em 1960, o maior, que é a sede, terá pouco mais de mil habitantes (1.098). Em Itupiranga registraram-se também algumas ocorrências de garimpo (esp. Ipixuna e Assumaúma) ${ }^{9}$.

A cidade de Tucuruí, no extremo norte da estrada, em 1960 terá 3.403 habitantes, 58,79\% do total do município (5.788). Viverá de uma pequena exploração da castanha, diamante e cristal de rocha; mas, especialmente, de sua função de baldeação. Esta tenderá a se interromper a partir de 1970 com a construção da rodovia PA-70, o chamado ramal de Marabá da Belém-Brasília, podendo ser retomado com a construção da rodovia Tucuruí-Marabá e o seu prolongamento em direção ao Xingu. Mas isso já diz respeito a uma nova fase na história da região.

${ }^{9}$ LARAIA, que percorreu a ferrovia em 1962, assim 3 descreve:

... O tempo de duração da viagem oscila entre 12 horas e uma semana. Os descarrilamentos são frequentes, porque predominam os dormentes podres. A situação agrava-se no 'inverno', exatamente durante a safra da castanha, quando a erosão pluvial ataca o mal conservado leito da estrada. Não existem horários de trens, o que é coerente com a impossibilidade de cumpri-los. As composições viajam sem os vagões para passageiros, amontoando-se estes nos carros destinados às cargas. Uma litorina atenua esta situação transportando 18 passageiros numa viagem de 8 horas. Mas, como o trem, não possui horário e sempre há dificuldade em obter um lugar (LARAIA e MATTA, p. 48) 


\section{BOI E CASTANHA}

\section{A Terceira Fase da frente Extrativista da Castanha}

Após a redemocratização, em 1945, a política no Pará definiu-se, tal como em muitos Estados brasileiros, por uma disputa em que se situava, de um lado, o Partido Social Democrático (PSD) e de outro uma coligação de outros partidos. A aliança que se consolidou no plano nacional entre o PSD e o Partido Trabalhista Brasileiro (PTB) não tirou no Pará, da mesma forma, aliás, como na maioria dos Estados brasileiros, a supremacia no agrupamento das mãos do PSD. Na coligação adversária, ao contrário da maioria dos Estados, sobressaia a liderança do Partido Social Progressista (PSP), e não da União Democrática Nacional (UDN), embora localmente em Marabá ocorresse o contrário. Por várias vezes, os dois agrupamentos revezeram-se no governo.

$\mathrm{Na}$ década de 50 o confronto político estava personalizado nas figuras do célebre Joaquim Magalhães Barata, do PSD, e do General Zacarias de Assunção, do PSP.

No final do mandato do General Assunção, em 1954, pela Lei n ${ }^{\circ}$ 913, de 4 de dezembro, foram introduzidas importantes modificações no arrendamento de terras devolutas do Estado para fins de exploração por indústrias extrativas.

Muito do que se dizia não apresentava novidade. Inicialmente concedia-se uma licença inicial de exploração por' uma safra. Depois da licença inicial, passava-se a um contrato de arrendamento por cinco anos (o primeiro ano sendo considerado a título precário). Porém, segundo uma das cláusulas dos direitos e obrigações dos arrendatários constante dos contratos, findo o prazo de arrendamento:

...se as cláusulas forem cumpridas até o final, fica automaticamente extinto o presente contrato a primeiro de setembro do último ano de sua duração, obrigando-se o arrendatário a entregar ao Governo as terras locadas, sem estrépito judiciário e sem direito a indenização pelas benfeitorias feitas, ficando-lhe, todavia, assegurado o direito de renovação, na forma do art. 36 da Lei $n^{\circ} 913$ (itálicos O.G.V.).

O direito de renovação do arrendamento constituiu-se, como terceiro passo, numa forma de aforamento perpétuo ${ }^{1}$, e assim foi entendido socialmente. Antes, na sutil letra da lei, cumpridas as exigências contratuais, o arrendamento poderia ser renovado, e caso não houvesse outro pretendente (ver cap. 5). Após 1954, tinha-se assegurado o direito de renovação, com pouca margem para disputas.

No único momento em que poderia haver margem maior para a flexibilidade estritamente política, e que foi o da escolha inicial, e aparentemente definitiva, dos arrendatários, a acomodação não deixou de estar presente, e mesmo alguns notórios e tradicionais pessedistas conseguiram manter seus castanhais. A área de manipulação e de jogo político certamente manteve-se, todavia, e encontrou guarida em outros instrumentos; o que levaria, alguns anos depois, o principal líder udenista de Marabá, e um dos beneficiários da Lei $n^{\circ}$ 913, que representava a situação local, a aderir ao PSD, que reconquistara o poder em âmbito estadual, para não ver a sua administração na prefeitura prejudicada ${ }^{2}$.

A curto prazo, a lei constituiu-se, porém, de fato, numa grande manobra política, fixando como arrendatários em grande parte os partidários do agrupamento então no Governo. Porém, a lei, que em sua redução política permite distinguir imediatamente a causa partidária, e consequências isomórficas, em uma redução social mais ampla revelaria consequências que, haveriam de mostrar-se de muito maior vulto, e que acabariam, em seus desdobramentos, inclusive a ter efeito sobre o quadro político.

De um ângulo regional, alíás, a política, no caso, era simplesmente o canal através do qual eram conduzidas as motivações e se davam as mediações com o planoextralocal, traduzindo formalmente em sua

${ }^{1}$ Próximo a Marabá, já havia casos de castanhais concedidos em aforamento pela prefeitura, em terras do município, por vezes sancionando, apenas, um fato consumado, e contribuindo para reduzir os castanhais livres do município.

Acabou tendo os seus direitos políticos cassados em 1964, o que não o impediu de continuar a ser uma das principais figuras da área, já que as fontes de seu poder não eram estritamente político-partidárias. Como prefeito, sua administração se notabilizou pelo asfaltamento da cidade de Marabá. 
linguagem interesses e lutas cujo conteúdo não era estritamente políticopartidário. Deve-se ressaltar que a demarcação dos castanhais não foi absolutamente rigorosa, ocupando de fato, seguidamente, áreas diversas vezes maiores do que as arrendadas.

Os investimentos. Um dos resultados do novo estatuto é aparentemente paradoxal. Como era aceito na sociedade regional que as provisões das leis anteriores no sentido de exigir determinados investimentos nos castanhais na verdade não se efetivavam, devido à existência de móveis de peso maior, através dos quais se concretizavam de fato as leis, tais provisões não tinham, realmente, consequência. No entanto, após 1954, quando a posse dos castanhais por parte dos contemplados passou a ser, em face dos poderes públicos, praticamente inconteste, é que começam a realizar-se com afinco os investimentos. Exatamente a segurança da posse, não mais ameaçada por mudanças na política ou por novas exigências de apoio, é que o permite. Antes, sabia-se que, realizando ou não os investimentos, a posse não dependia absolutamente disso, e poder-se-ia estar semeando para outros colherem. Dever-se-ia, pelo contrário, aumentar cada vez mais o ritmo e a intensidade do processo predatório e de exploração da mão-de-obra. Agora, sem dúvida, tratava-se de aplicação em benefício próprio, e a realização dos investimentos era, circularmente, a única garantia necessária para deles usufruir. Era, também, uma maneira de utilizar a capacidade ociosa durante a entressafra. Dá-se, assim, um aumento na relação entre o capital constante e o capital variável.

Pecuária. Os investimentos realizados consistiram nas melhorias a que a lei se referiu (abertura de estradas, construção de abarracamento, plantio de roçado etc.), mas também em outros. Entre estes, destaca-se o espetacular aumento e melhoria do rebanho bovino, com o que se realizava um investimento produtivo de retorno mais lento do que o da castanha, e ao mesmo tempo com algumas características de segurança maior, que o tornavam, pela própria diversidade, interessante para conglomerar com a atividade extrativa. Mesmo porque, a tradição de combinação de atividades comerciais e produtivas de várias espécies, como vimos, já existia na região.

Esse crescimento do rebanho foi estimulado, ainda, pelo indício do crescimento demográfico efetivo no Pará a partir a década de 40, particularmente em seus centros urbanos. A população do município da capital, que de 1920 a, 1940 decrescera de 236.402 habitantes para 206.331, em 50 recupera-se em parte, embora ainda com um incremento abaixo do crescimento vegetativo, e chega a 254.949 , donde parte para um incremento razoável que a eleva em 1960 a 402.170 habitantes. A cidade de Belém manteve sua posição de sétima cidade em população do país nos três censos, com 164.673 habitantes (1940), 230.181 (1950) e 359.988 (1960), numa época em que as grandes cidades brasileiras cresceram significativamente. Em 1970 registrará uma população de 572.654 habitantes, mantendo a sua posição (FIBGE, 1971 a, p. 98).

Mas Belém não é o único centro urbano que cresce. Destacam-se também em tamanho Santarém, Bragança, Capanema, Castanhal, Abaetetuba. Outros centros menores que se desenvolvem em torno de Belém, especialmente na zona Bragantina e no Salgado, também terão influência mais do que local pelo seu número e concentração. Mesmo a própria cidade de Marabá já se constituirá num mercado de proporções modestas, com cerca de seis mil habitantes em 1955, e em crescimento relativamente rápido, já que no decorrer da década de 40 já sofrera um aumento considerável ${ }^{3}$.

Isso tudo cria um razoável mercado consumidor de carne, que, no entanto, as áreas tradicionais de pecuária da Amazônia não conseguiam prover. Se se tratasse apenas da pecuária de Roraima e Amapá, o isolamento físico mesmo e as longas distâncias poderiam satisfazer como explicação para isso. Mas trata-se, principalmente, de Marajó, bem próximo a Belém. Aparentemente, estamos diante das dificuldades de uma pecuária extensiva e de campo (inundável) do tipo tradicional brasileiro, em circunstâncias especialmente complicadas, readaptar-se para atender a um forte estímulo externo. Isso apesar do esforço realizado na época 'da borracha, no início deste século, com a introdução do búfalo indiano através das Antilhas. É assim que ANDRADE sintetiza a descrição da pecuária de Marajó:

Assim, com o gado criado solto, migrando conforme o subir ou o descer das águas, sem que se faça seleção de raças e sem que se dê ao mesmo um certo arraçoamento, a produção é pequena, bastando apenas para atender ao consumo local e, em parte, ao consumo de Belém (ANDRADE, p. 54)

${ }^{3} 2.984$ habitantes em 1940; 4.973 habitantes em 1950 . 
No início da década de 50, instala-se uma séria crise no abastecimento de carne em Belém. Tem-se de recorrer à importação de gado de fora do Estado, de Goiás, da Baixada Maranhense etc. E é nessas circunstâncias que irá estimular-se o desenvolvimento de novas soluções, que implicarão uma criação em plena Amazônia de uma pecuária de caracteristicas capitalistas modernas, no baixo Amazonas (em torno de Santarém) e no Sul do Pará.

O Governador do Estado, Gal. Assunção, irá pessoalmente a Marabá discutir a questão com os fazendeiros locais, entre os quais destacam-se aqueles que estavam voltados para o abastecimento local de carne bovina. É deles que parte a reinvidicação de crédito e transporte. E sinal de que o isolamento físico por si tem fraco valor explicativo é que, nessas circunstâncias, instala-se uma linha aérea de transporte de gado abatido de Marabá para Belém. Esta irá funcionar até a abertura do ramal rodoviário da PA-70, embora caindo um pouco a partir de 60 com abertura da BelémBrasília, a qual abre novas possibilidades menos onerosas de importação de gado para Belém. Não se interrompe, porém, e com o ramal volta a aumentar a exportação.

De inicio, pelo menos até a abertura da Belém-Brasília, o que se irá fazer predominantemente é aproveitar as invernadas existentes e ampliá-las para a engorda do gado que é trazido de Goiás e Maranhão para lá ser abatido e transportado por via aérea.

Porém, no final dos anos 50 Marabá já estará se tornando autossuficiente em matéria de carne bovina, pela rápida ampliação da base pecuarista anterior, possibilitada, inclusive, pelo crédito que lhe é aberto em Belém. Passará a exportar, juntamente com o vindo de fora, o seu próprio gado; embora de inicio em quantidades reduzidas. Para Marabá, apesar das exportações, mesmo até o final da década de 60 ainda se tratará antes de mais nada de atender ao consumo local e da formação do rebanho. Em 1969 exportou-se perto de três mil reses, sendo cerca de $50 \%$ gado de engorda. Enquanto isso, a própria cidade de Marabá consumiu durante o ano cerca de quatro mil cabeças, o que ainda a mantinha como o mercado preferencial.

Sessenta anos depois do sonho pecuarista dos fundadores do Burgo Agrícola do Itacaiúnas, surgem as condições para que ele se concretize. E aquilo que no final do século anterior havia impossibilitado o seu desenvolvimento - a inexistência de campos naturais - é o que irá agora emprestar à sua pecuária caracteristicas de alta racionalidade, em termos de Brasil, num meio definido até então pela exploração econômica predatória.

Tratar-se-á - ao contrário da criação tradicional do Brasil Central (ver cap. 3) - de uma pecuária de custos elevados, dado o investimento exigido pela derrubada da mata amazônica e o plantio de pastagem artificial (capim colonião, jaraguá e napier); além do cercamento dos pastos, imprescindível nesse meio.

Nessas circunstâncias, não se justificava que feito esse investimento se continuasse a utilizar o gado tradicional do Brasil Central, o chamado péduro ou curraleiro, de produtividade muito baixa. Com isso vai-se apurando a criação, com a introdução de reprodutores zebu - gir e nelore - da melhor qualidade, provindos do Triângulo Mineiro (Uberaba e Uberlândia), com os quais, aliás, só se faz uma boa seleção racial quando cercados.

O rebanho cresce em qualidade, e também em quantidade. Em 1969 era calculado em cerca de 70.000 cabeças no total, sendo $51.000 \mathrm{em}$ Marabá, 8.000 em São João do Araguaia, 5.000 em Tucuruí e 3.000 em Itupiranga e Jacundá. $\mathrm{O}$ aumento da exportação por essa época deve ter diminuído temporariamente o tamanho do rebanho.

A quadra de pasto (4,8 ha) suporta em média 10 reses no inverno e 5 no verão; o peso médio da cabeça de gado vai de 300 a $400 \mathrm{~kg}$, mas alcançando até $500 \mathrm{~kg}$, e o aproveitamento é de 50 a $60 \%$ do peso total ${ }^{4}$. O gado de dois anos já dá cerca de $170 \mathrm{~kg}$ de peso, o que representa mais do que o gado de cinco anos do Brasil Central quando criado solto.

As pastagens são em geral colocadas junto aos castanhais. Planta-se quase sempre somente o capim, sem a preocupação com uma cultura intercalada, o que provoca certa reação entre os não-pecuaristas. Embora até agora não se tenha posto em termos globais a questão da substituição da castanha pelo gado, antes tratando-se de um consórcio, em alguns casos isolados, especialmente nos arrabaldes da cidade de Marabá, tem havido a substituição por pastagens da castanheira, o próprio símbolo da prosperidade de Marabá. Nesses casos, a opção tem de ser radical, já que a

${ }^{4}$ Segundo ANDRADE, no Sul de Goiás, onde a criação é considerada de qualidade razoável, o peso médio do boi azebuado para abate é de $245 \mathrm{~kg}$, e 180 a $190 \mathrm{~kg}$ para o crioulo, sendo o rendimento do primeiro de $57,9 \%$ e do segundo de $50 \%$ (p. 185). 
castanheira, apesar de toda a sua imponência, é extremamente sensível ao fogo da queimada e não sobrevive em campo aberto.

Organização do trabalho. O consórcio castanha-gado e os outros investimentos realizados permitiram uma utilização mais plena do fator terra, com atividades a serem levadas a cabo durante todo o ano, que em parte são preparatórias da safra, e que tornam o castanhal menos dependente do comércio local. Com isso, surgiram importantes modificações na organização do trabalho. Agora, tinha-se necessidade de certo volume de mão-de-obra o ano todo, já que havia obras a realizar e não se tratava de uma pecuária extensiva. Por outro lado, na época da safra diminuía em relação às fases anteriores essa necessidade, pelo aumento na produtividade da mão-de-obra com os investimentos realizados, que permitiam, por exemplo, que com as novas vias de acesso, em vez do castanheiro deixar de lado a sua atividade periodicamente para transportar a castanha, que se fosse buscá-la onde ela estivesse, transportando-se de uma vez volumes maiores. A produtividade média do castanheiro por ocasião do grosso passa de aproximadamente 2 para 3 hl de castanha em média por dia, durando a safra um período maior. Hoje, para os castanhais mais afastados, chega-se 'a transportar os castanheiros em avião monomotor, para que não gastem no deslocamento dias e semanas, e com isso possam aproveitar mais plenamente o tempo da safra. Grande parte dos castanhais já possui campo de pouso. Em alguns casos, a redução da mão-de-obra durante a safra alcançou mais de $50 \%$.

Com isso, dá-se uma fixação maior da mão-de-obra, e reduz-se o número daqueles que realizam migrações sazonais. Por isso mesmo, provavelmente, hoje, é difícil encontrar-se migrantes do baixo Tocantins, que tradicionalmente realizavam esse movimento. Tem-se, porém, nordestinos, especialmente maranhenses, que realizam em volume cada vez maior, como veremos no capítulo seguinte, migrações de caráter mais definitivo, com isso, também, reduzindo as possibilidades dos migrantes meramente sazonais. Embora esses nordestinos em sua maioria tenham na lavoura a sua atividade principal, sempre apresentam uma proporção ponderável entre os mais pobres que na época da safra empregam-se na castanha. Tudo isso contribui aos poucos para reduzir a imagem de aventura e violência que se associa a Marabá.
Embora continue a aumentar expressivamente o número de trabalhadores por ocasião da safra, e as novas tendências não penetrem com a mesma rapidez em todos os casos, as variações anuais de mão-de-obra são menores; o que não significa que os indivíduos num estabelecimento sejam sempre os mesmos. Em geral não permanecem mais de um ou dois anos, indo depois para um garimpo ou procurando estabelecer-se por conta própria na lavoura, como veremos; a não ser no caso de determinados indivíduos de confiança, especialmente os encarregados, ou os que ficam presos pelo sistema de dívidas. De qualquer maneira, considera-se entre os patrões que essa redução permite uma seleção melhor; ou seja, melhoram as condições para os que estão do lado da procura de mão-de-obra. E é mais fácil evitar fenômenos como o dos indivíduos que se aviam com dois, três patrões no início da safra e depois fogem, o que ocorre mais com os menos fixos na região.

Eis uma ilustração concreta da distribuição de trabalho a realizar durante o ano numa fazenda do Rio Sororó cm 1969, que ajuda a entender a redução parcial na flutuação da mão-de-obra:

1. Duas famílias cuidando do gado (4 vaqueiros). (Não possuíam roça própria. Ganhava cada um Cr\$ 150,00.)

2. Duas famílias construindo e reparando barcos para a época da safra.

3. Uma família fazendo queijo.

4. Uma família fazendo paneiros para a castanha. (Ganhava $\mathrm{Cr} \$ 1,50$ por paneiro, fazendo 3 por dia; o fazendeiro revendia ao castanheiro por Cr\$15,00 cada um.)

5. Uma família do encarregado (que também cuida da loja) (Cr\$ $500,00)$.

6. Uma família cuidando da pensão dos trabalhadores.

7. Duas famílias cuidando das roças por empreitada.

8. Duas famílias fazendo farinha. Recebiam por diária. (Saía para o fazendeiro por $\mathrm{Cr} \$ 5,00$, que revendia ao castanheiro por $\mathrm{Cr} \$$ 15,00.)

9. Duas famílias e mais dez homens solteiros que de fevereiro a maio trabalham como pilotos de barco. Durante o resto do ano trabalham por empreitada na broca, derrubada e limpeza das quintas (pastagens), limpeza de estradas, de roça, de grotões, conserto de cercas, de mata-burros etc. 
10. Mais 22 homens, cujo serviço varia durante o ano, trabalhando na juquira (preparo de roça e, especialmente, das pastagens) e serviço de manutenção.

Há muita mobilidade da mão-de-obra; são considerados volantes. Mais estáveis são os administradores e um ou outro homem de sua confiança. $\mathrm{O}$ pagamento é quase todo feito $\mathrm{cm}$ dinheiro, seja em salário, diária ou por empreitada, variando conforme esteja ou não incluída a alimentação. Em geral os vaqueiros, considerados mais fixos, recebem salário e os demais por empreitada. Seguidamente a empreitada é recebida por um indivíduo, que a realiza pagando por sua vez diária a certo número de trabalhadores ${ }^{5}$. Ao contrário da frente pecuarista que dera origem indiretamente a Marabá, c que mantivera muitas de suas características em outras partes no Brasil Central, agora desconhece-se a partilha com o vaqueiro, pois aqui o gado é por demais valorizado, e não existem campos naturais à disposição do vaqueiro sem exigir investimento. Trata-se agora do vaqueiro proletário. A partilha só será realizada com quem possui pastagens e aluga ao fazendeiro.

Este fazendeiro do Rio Sororó possui cerca de 20 castanhais de produtividade variada. Na época da safra, emprega cerca de 400 castanheiras. Os que ficam devendo no final da safra em geral continuarão trabalhando nas fazendas durante $o$ ano. A não ser quando fogem da região, a única possibilidade nesse caso de não continuar trabalhando para o mesmo patrão é outro se responsabilizar por suas dívidas.

Os fazendeiros em geral dão preferência aos trabalhadores que não possuem família, quase sempre mais novos e podendo ser deslocados com maior facilidade.

No castanhal, portanto, vai-se optando por uma redução no volume da mão-de-obra e um aumento de sua produtividade. Com isso, aparentemente o sistema de extração da mais-valia pelo sistema do barracão vai-se tornando menos importante. Quanto a isso, hoje pode-se distinguir entre o bom patréio e o mau patréio, sendo que o bom - aquele que cobra preços próximos aos de Marabá no barracão - em geral está entre os que

${ }^{5}$ A remuneração exata das empreitadas vigente na região no ano de 1969 será fornecida adiante. mais racionalizaram a sua produção. No entanto, são poucos os que abrem mão inteiramente desse instrumento. Eis um quadro comparativo das mercadorias mais procuradas com os preços de Marabá e os de um barracão situado a três dias de viagem de Marabá (safra 1968-69):

QUADRO VII

\begin{tabular}{|c|c|c|c|}
\hline Mercadoria & Marabá & Mata & $\begin{array}{l}\text { Percentual de } \\
\text { diferença }\end{array}$ \\
\hline 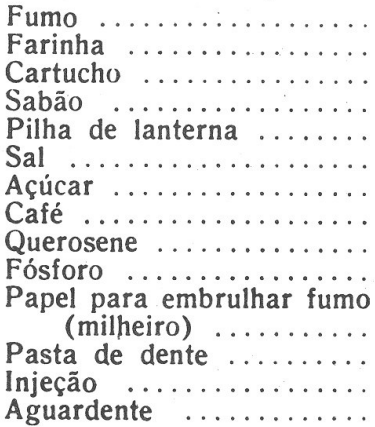 & $\begin{array}{r}3,00 \\
7,00 \\
12,00 \\
0,40 \\
0,80 \\
0,30 \\
0,80 \\
2,00 \\
0,60 \\
0,50\end{array}$ & $\begin{array}{r}15,00 \\
16,00 \\
25,00 \\
2,50 \\
3,00 \\
1,00 \\
3,00 \\
3,00 \\
1,50 \\
3,00\end{array}$ & $\begin{array}{r}400 \% \\
128 \% \\
108 \% \\
525 \% \\
275 \% \\
233 \% \\
275 \% \\
50 \% \\
150 \% \\
500 \%\end{array}$ \\
\hline
\end{tabular}

$\mathrm{Na}$ mesma ocasião, nesse ponto da mata estava-se vendendo 9 hectolitro de castanha por $\mathrm{Cr} \$ 4,50$ e em Marabá por Cr\$ 6,00, com um acréscimo de $33 \%$ que podemos supor seja por conta do lucro e das despesas de administração e de frete da viagem de burro e motor. Imaginando que a administração e o transporte das mercadorias no mesmo trajeto em sentido contrário onere mais do que o da castanha, poderíamos supor como equivalente um acréscimo médio aproximado para esse caso de 45\% sobre o seu valor em Marabá, abstraindo a possibilidade de pela quantidade o patrão comprar mais barato. Partindo dessa hipótese, e sem levar em conta outros fatores, teríamos, ainda hoje, os seguintes percentuais na margem de lucro na venda das mercadorias no barracão, acima do lucro na castanha propriamente, nesta etapa da comercialização. 
QUADRO VIII

\begin{tabular}{|c|c|}
\hline Mercadoria & $\begin{array}{l}\text { Perc. hipotético de } \\
\text { lucro adicional }\end{array}$ \\
\hline 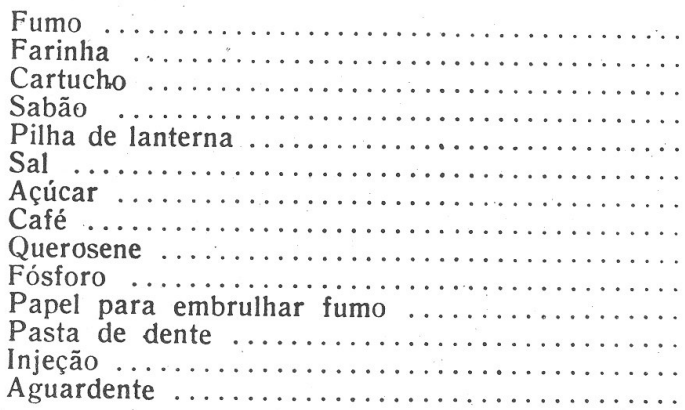 & $\begin{array}{r}355 \% \\
83 \% \\
63 \% \\
480 \% \\
230 \% \\
188 \% \\
230 \% \\
5 \% \\
105 \% \\
455 \% \\
5 \% \\
155 \% \\
55 \% \\
522 \%\end{array}$ \\
\hline
\end{tabular}

A margem de lucro varia consideravelmente conforme a mercadoria, podendo o patrão manipular os preços com grande liberdade conforme os seus interesses e a maneira pela qual vê a estrutura de necessidades dos castanheiras.

Trata-se, porém, obviamente, de um lucro decrescente em termos relativos à medida que ao mesmo tempo que aumenta a produtividade diminui o volume de mão-de-obra empregada é consequentemente o volume de mercadorias vendidas. No entanto, ainda serve para ajudar a tranquilizar e garantir os patrões quanto aos riscos imprevisíveis da castanha, como a redução na safra, oscilações de preços, atrasos nas chuvas interrompendo as comunicações nos igarapés etc. Para certos efeitos, tratase do mesmo tipo de garantia que se procura agora com a pecuária a longo prazo e em moldes modernos, contra os azares da atividade extrativa; mesmo tendo diferido significativamente em alguns resultados concretos e na sua relação com o fator trabalho.

Deve-se acrescentar que após 1964 o roubo na cabeça do hectolitro foi reduzido, pela transformação oficial por parte do Estado do hectolitro da castanha efetivamente em 100 litros, o que tende a fazer desaparecer, apesar de sérias resistências, outro dos diversos expedientes de exploração utilizados.
Lucro da castanha. Eis um cálculo aproximado de despesas e de lucro de um dono de castanhal por hectolitro de castanha na safra 1968-69, que serve, também, para dar uma ideia mais concreta das diversas etapas de comercialização. Supõe-se o preço de venda em Belém a Cr\$ 55,000, que foi o valor modal na safra, quando variou de $\mathrm{Cr} \$ 42,00$ a $\mathrm{Cr} \$ 60,00$ :

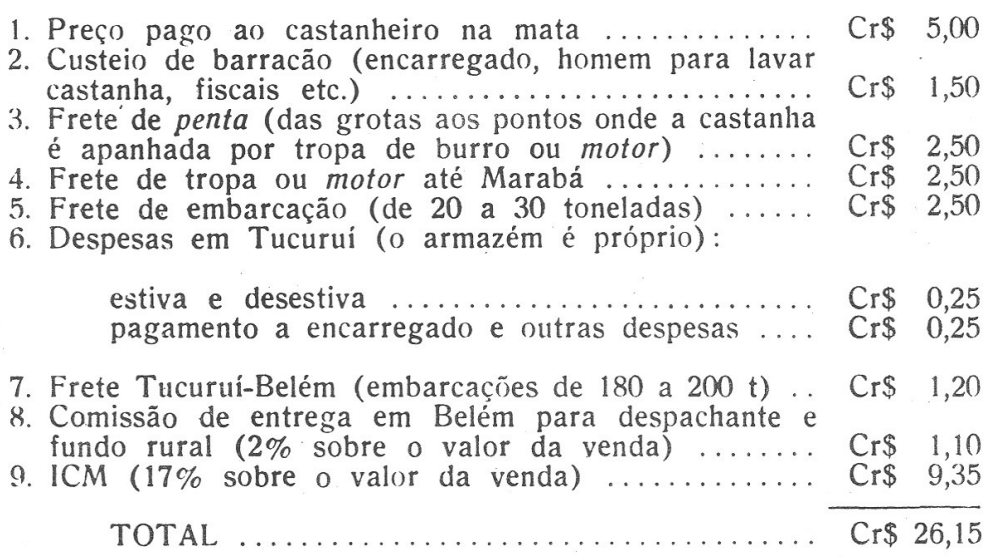

Acrescentando mais uma certa quantia por conta das despesas de preparação para a safra na fazenda desde junho, com serviços de manutenção, de roça e de pecuária para abastecimento (broca, derrubada, limpeza de quintas, estradas, mata-burros etc.), poderíamos ter cerca de $\mathrm{Cr} \$$ 30,50 de despesa por hectolitro. A um valor de venda de $\operatorname{Cr} \$ 55,00$, teríamos um lucro por hectolitro de cerca de $80 \%$.

Embora esse dado isoladamente possa ser enganador, é interessante assinalar também que a razão entre o preço pago ao apanhador pela castanha $(\mathrm{Cr} \$ 5,00)$ e o preço recebido pelo comerciante $(\mathrm{Cr} \$ 55,00)$ diminuiu de 0,172 para 0,09 em comparação cornos, dados fornecidos por PATERNOSTRO para 1935 (ver cap. 5). Isso pode indicar uma tendência a concentrar a exploração mais diretamente na produção, em detrimento do mecanismo comercial do barracão.

É preciso que se diga que esse dono de castanhal é um dos mais racionalizados e, ao mesmo tempo, dos que menos auferem lucro nas, vendas do barracão, segundo o consenso geral. Chegou a ter 120 homens trabalhando para ele durante a safra como apanhadores de castanhas e mais 
40 no transporte como fiscais etc. Coloca-se logo abaixo das principais empresas extrativistas. Pode ter tido um lucro aproximadamente de $\mathrm{Cr} \$$ $500.000,00$ com cerca de $20.000 \mathrm{hl}$ colhidos. Boa parte desse lucro deverá ter sido investido na pecuária, quando um bom reprodutor em Marabá no ano de 1969 custava até $\mathrm{Cr} \$ 15.000,00$.

Os bancos, a castanha-pecuária e a decadência do comércio de Marabá. Apesar dos empréstimos abertos para a pecuária (onde avulta, atualmente, o financiamento do BID que em Marabá é feito através do Banco da Amazônia S.A.), estes são considerados insuficientes e caros. Especialmente nos últimos anos, quando o desenvolvimento da pecuária é ainda mais estimulado por esforços semelhantes feitos em áreas próximas por pecuaristas do Sul. Em parte isso ocorre, todavia, exatamente porque a entrada desses novos pecuaristas (que, como veremos, nada têm a ver com a castanha) à beira das estradas que vão sendo abertas, torna menos crucial do ponto de vista do Estado, a pecuária de Marabá propriamente.

Isso poderia ter liquidado ou pelo menos retardado o desenvolvimento da pecuária de Marabá, não fosse, mais uma vez, a castanha; já que o avanço da pecuária por enquanto se apóia na castanha e não a substitui. Não só os lucros da castanha continuaram a sustentar a pecuária, como também, seguidamente, os novos empréstimos bancários concedidos para a castanha são desviados para a pecuária, o que por vezes traz dificuldades à atividade tradicional.

No final da década de 50 instala-se o primeiro banco em Marabá: o Banco da Amazônia S.A. E em 1964 é aberta uma agência do Banco do Brasil. Juntamente com a diversificação de atividades nos castanhais e a abertura da Belém-Brasília, a presença dos bancos vai contribuir decisivamente para libertar os arrendatários de castanhal dos tradicionais comerciantes locais. O Banco do Brasil, por exemplo, na safra 1968-69 concedeu em média cerca de $\mathrm{Cr} \$ 50.000,00$ de empréstimo para cada dono de castanhal. Com esse dinheiro, vai-se preferir, em geral, a compra direta de mercadorias fora de Marabá. O comércio tradicional sofreu muito e essa situação modernizante não deixou de ter certos efeitos paradoxais, com a diminuição da importância da praça de Marabá, o que, por um efeito multiplicador, tem sua influência sobre a vida da região. Diversos comerciantes de Marabá fecharam os seus negócios e transferiram-se para outras regiões, devido às novas facilidades bancárias e às melhores comunicações que quebram o seu poder oligopolista. A decadência do comércio de Marabá identificou-se com a diminuição da capacidade polarizadora da cidade de Marabá, a cidade dos comerciantes, que vai se dando com o começo do fim da "longa noite" de involução da Amazônia Oriental e do Meio-Norte. Muitos dos comerciantes que eram também donos de castanhal fecham o seu comércio, e passam a dedicar-se exclusivamente à castanha e à pecuária. São poucos, hoje, os donos de castanhal que ainda possuem comércio na cidade; e quando o possuem, a relação de subordinação entre as duas atividades é invertida. Finalmente, pelo menos ao nível local, o controle direto da produção supera, como fonte de poder, o controle mercantil, embora sob a égide de um poder financeiro maior, onde avulta o Estado. A tendência à concentração da produção, conforme veremos, também facilita isso.

No decorrer da década de 60 realizaram-se em Marabá duas exposições pecuaristas, que atraíram criadores de fora.

A concentração. De 1954 em diante, após a Lei no 913 e os novos investimentos realizados, acelerou-se o processo de concentração na apropriação da terra ligada à castanha e à pecuária. Com isso deu-se uma segunda grande expropriação de produtores, a ponto de reduzir-se a cerca de metade o número de donos de castanhal (que no início desta fase era aproximadamente de noventa), e, mesmo dentro desse conjunto, concentrarse nas mãos de apenas uns seis grupos econômicos maiores boa parte da produção. Durante a fase de arrendamento a prazo, após as expropriações consequentes à sua própria implantação, não deixa de haver certa concentração; porém nada que se compare com o processo que se seguiria, com o qual surgiria, efetivamente, a grande empresa extra ti vista e pecuarista.

Continua-se a ter, ao lado de castanhais ocupando mais de 200 castanheiros, outros que ocupam, por exemplo, apenas 10. Porém, ocorre que um mesmo individuo ou grupo passa a controlar um número de castanhais e fazendas cada vez maior. As transações, que anteriormente se davam apenas em alguns casos, aumentam em número, e são mais dirigidas no sentido da concentração. Os maiores donos de castanhais organizam-se em firmas modernizadas, que combinam atividades variadas, entre as quais acrescenta-se, até, em alguns casos, a compra, beneficiamento e venda de arroz da pequena agricultura nascente. A maior dessas firmas apresentou, 
em 1969, como garantia para um empréstimo, bens no valor de Cr\$ 10.000.000,00, situados em Marabá e Belém. Ocorrem diversas transações de venda de castanhais que se aproximam de 1 milhão de cruzeiros.

A Lei no 913 contribuiu decisivamente para o desencadeamento desse processo. Porém outros fatores também tiveram importância. Entre eles o novo modo de operação através de bancos. Apesar das contradições de interesses em certo nível entre exportadores e produtores de castanha no antigo sistema de empréstimo, havia um nível mais profundo em que se dava um encontro de interesses básico, e que se realizava por espécies de pactos de natureza pessoal que permitiam certa flexibilidade. As operações com os bancos não têm essa característica; e como, por outro lado, as possibilidades de crédito são maiores, não foram poucos os donos de castanhal que se atolaram em dívidas por falta de uma contabilidade e de uma aplicação adequadas, e foram obrigados a passar adiante os seus castanhais. Também as dificuldades do comércio trouxeram problemas para aqueles que combinavam as duas atividades. E a própria transição para uma atividade pecuarista consorciada fez muitos fracassarem, dado os investimentos necessários, muitas vezes retirados, além do viável, da castanha; e dado o fato de os lucros, aqui, não terem o caráter quase imediato do da castanha. Além disso, a experiência vai demonstrando que, ao nível em que se coloca, a pecuária na região só produz lucros efetivos com rebanhos acima de 400 cabeças, devido aos investimentos infraestruturais necessários; e os empresários que não conseguiram alcançar esse ponto viram-se em dificuldades.

Mas há um outro sentido também em que a pecuária contribuiu para a concentração. É que os rebanhos dos maiores criadores tendem a crescer mais rapidamente do que a possibilidade de plantio de pastos artificiais. Com isso, dá-se lima verdadeira corrida entre o aumento do rebanho e a disponibilidade de pastagens, o que estimula a ocupação de novas terras e a compra de pastagens por parte dos maiores criadores. O maior deles terá, em 1969, aproximadamente dez mil cabeças, e o segundo colocado cerca de seis mil. Somado às dificuldades sentidas pelos donos de castanhal e pecuaristas menores, a tendência é clara.

Hoje tem-se um pequeno núcleo de grandes empresas, empregando na safra da castanha acima de 250 apanhadores seguido de uma camada intermediária de donos de castanhal um tanto mais modestos, que empregam em média em torno de 100 apanhadores. Por debaixo dessa camada, ocupando a posição correspondente ao dos antigos pequenos arrendatários de castanhal, tem-se, ao lado de alguns sobreviventes deste tipo, especialmente subarrendatários de castanhal. São pouco mais de cem indivíduos, alguns antigos arrendatários, cujo acesso à terra só pode ser feito por intermédio dos arrendatários diretos. Subarrendam um castanhal por uma safra, em geral dos grandes donos ou, então, de proprietários absenteístas, ocupando em geral de 40 a 60 homens, e realizando o pagamento ao arrendatário, com quem geralmente se aviam, seja através de pagamento de um preço fixo combinado anteriormente, seja através da venda da castanha por um preço menor do que o corrente ou pela entrega de uma parte da castanha colhida (40 a 50\%). São sujeitos a explorações análogas aos do pequeno castanheiro, embora em outro nível, inclusive com a fabricação de dívidas adicionais inexistentes no aviamento. Aparentemente, no final da década de 60 a posição dessa camada tornava-se cada vez mais difícil.

GRUPOS IMPORTADORES NO ESTRANGEIRO

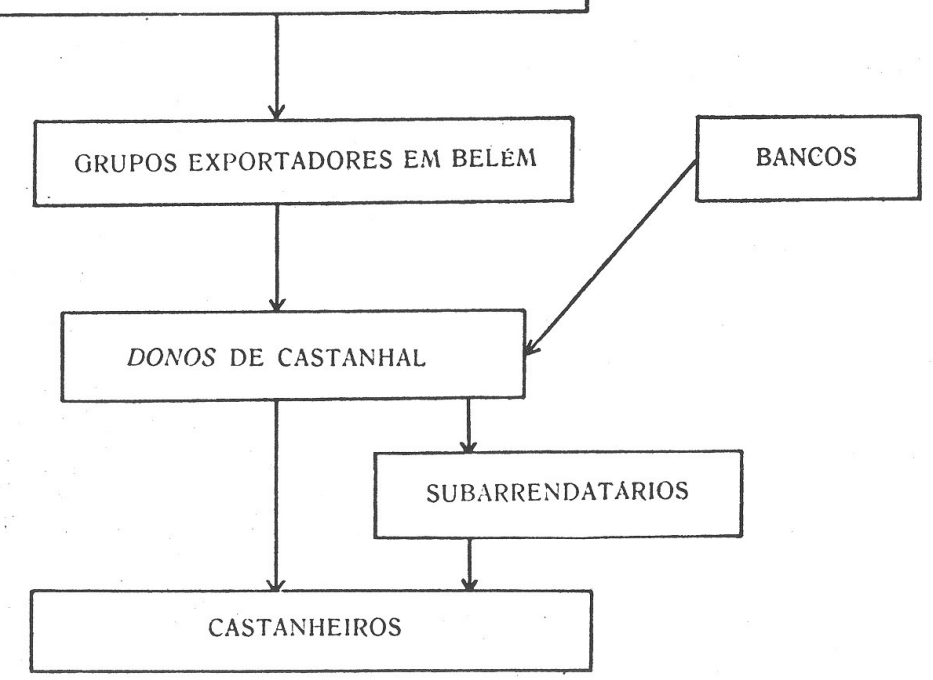


Produtores e exportadores. Esta concentração e as novas ligações com os bancos também diminuíram em certa medida a dependência em relação aos exportadores de Belém. Esta permanece muito grande; porém redobram-se os esforços para quebrá-la, chegando um dos principais grupos de Marabá a conseguir montar a sua própria firma exportadora. A venda antecipada da castanha aos exportadores vai gradativamente diminuindo. Em 1967 realizou-se em, Belém uma Conferência Nacional da Castanha do Pará, com o apoio da Confederação Nacional da Agricultura. Nessa Conferência, bem como em outras oportunidades, tem-se acentuado a necessidade de abrir-se efetivamente o mercado interno para a castanha-dopará, com exportação direta para o Sul, sem passar por Belém ${ }^{6}$. Isso tem sido difícil, em vista da concorrência das castanhas estrangeiras, vendidas a preço mais barato e tendo já um mercado conquistado dada uma estrutura de necessidades determinada. Por ocasião das festas de fim de ano em 1969 no Rio de Janeiro, havia uma variação de preços para o quilo da castanhado-pará (descascada) no mercado que ia de $\operatorname{Cr} \$ 7,80$ a $\operatorname{Cr} \$ 8,50$, ao passo que o da castanha portuguesa oscilava entre $\mathrm{Cr} \$ 2,50$ e $\mathrm{Cr} \$ 3,00$. Além disso, ao passo que todos os estabelecimentos comerciais do ramo vendiam a castanha portuguesa, não era fácil encontrar a castanha-do-pará, que só aparecia nas maiores casas. É de se notar que afora a baixa produtividade da exploração da castanha-do-pará e os custos de transporte, a diferença de preços devia-se, também, por um lado aos favores concedidos à importação da castanha portuguesa e, por outro, aos próprios preços internacionais da castanha-do-pará, que não tornam em geral interessante a venda a preços mais baixos no mercado interno.

A venda no mercado interno é vista mais como um recurso por assim dizer político por parte dos produtores, para aumentar o seu poder de barganha em face dos exportadores. Para isso têm pleiteado favores especiais do Governo, sem maior sucesso até agora, quais sejam estímulo à propaganda, inclusão da castanha na merenda escolar, nos planos assistenciais de proteção e pré-escolar, na alimentação habitual das forças armadas, nas rações de emergência e sobrevivência, isenção de impostos etc.

Tem-se discutido também, nos últimos anos, a realização do beneficiamento da castanha em Marabá. Trata-se de processo muito

\footnotetext{
${ }^{6}$ Ver Bases para uma Política Nacional da Castanha.
}

simples, levado a cabo até hoje quase que em caráter de manufatura em sete fábricas de Belém, que não conseguem dar conta de toda a produção ${ }^{7}$, e que consiste em descascar, estufar e enlatar o produto ${ }^{8}$. Isso não só aumentaria a parte do lucro que ficaria com os de Marabá, como aumentaria a possibilidade de jogo no mercado. Além disso, tem-se pensado também no aproveitamento do óleo da castanha.

A luta entre exportadores e produtores tem-se tornado cada vez mais renhida nos últimos anos. E a castanha-do-pará continua a manter posição de destaque no quadro geral da produção: em 1967, o valor da sua produção no Estado do Pará foi de Cr\$ 8.887.019,00, ao passo que o da borracha no mesmo Estado foi de Cr\$ 5.103.711,009. Em 1968 o valor da exportação foi de 14.969.000 dólares.

Os quadros adiante ajudarão a dar uma visão da situação da castanha.

\footnotetext{
${ }^{7}$ Aparentemente, não há maior interesse em aumentar as instalações industriais dado o fato de tratar-se de atividade sazonal, em que as instalações durante parte do ano permanecem com capacidade ociosa.

${ }^{8}$ As primeiras fases rudimentares de beneficiamento são realizadas na própria área, de início com a abertura do fruto e retirada das amêndoas pelo próprio castanheiro, seguida do ensacamento para transporte até a sede. Depois, na sede do castanhal ou em Marabá, as amêndoas são imersas na água dentro de cestos ou paneiros para eliminação das amêndoas imprestáveis, que sobem à tona.

Em Belém: "As amêndoas são introduzi das várias horas em tanques de água quente, passando depois por autoclaves, para finalmente serem descascadas em máquinas manuais simples. Daí passam à seleção, por tamanho e qualidade, e são levadas à estufa para secagem, embaladas em latas de folhas de flandres ou caixas de papelão, ficando prontas para a comercialização. Apenas uma parte da produção é beneficiada, sendo a maior percentagem exportada com casca a granel...” (BAPTISTA).

${ }^{9}$ Ver Correio da Manhã, 26/2/1970. 
QUADRO IX

QUANTIDADE DE CASTANHA-DO-PARÁ PRODUZIDA SEGUNDO AS UNIDADES DA FEDERAÇAO E AS ZONAS FISIOGRÁFICAS - 1967

\begin{tabular}{|c|c|}
\hline $\begin{array}{c}\text { Unidades da Federação e Zonas } \\
\text { Fisiográficas }\end{array}$ & $\begin{array}{l}\text { Quantidade } \\
(\mathrm{t})\end{array}$ \\
\hline Rondônia & 1.587 \\
\hline Alto Madeira & 1.587 \\
\hline Acre & 4.000 \\
\hline Alto Purus & 4.000 \\
\hline Amazonas & 8.366 \\
\hline $\begin{array}{l}\text { Médio Amazonas } \\
\text { Rio Negro } \\
\text { Solimōes-Tefé } \\
\text { Rio Purus } \\
\text { Rio Juruå } \\
\text { Solimōes-Javari } \\
\text { Rio Madeira }\end{array}$ & $\begin{array}{r}1.512 \\
379 \\
2.165 \\
2.176 \\
5 \\
32 \\
2.097\end{array}$ \\
\hline Roraima & 52 \\
\hline Catrimâni & 52 \\
\hline Amapd́ & 1.238 \\
\hline $\begin{array}{l}\text { Marzagão } \\
\text { Amapá-Macapá }\end{array}$ & $\begin{array}{r}1.212 \\
26\end{array}$ \\
\hline Pará & 18.868 \\
\hline $\begin{array}{l}\text { Marajó e Ilhas } \\
\text { Bragantina } \\
\text { Guajarina } \\
\text { Tocantina } \\
\text { Jacundá-Pacujả } \\
\text { Baixo Amazonas } \\
\text { Itacaiúnas } \\
\text { Rio Xingu } \\
\text { Planalto } \\
\text { Tapajós }\end{array}$ & $\begin{array}{r}15 \\
3 \\
255 \\
543 \\
40 \\
948 \\
16.577 \\
236 \\
200 \\
51\end{array}$ \\
\hline Mato Grosso & 53 \\
\hline $\begin{array}{l}\text { Aripuanã } \\
\text { Chapada } \\
\text { Encosta Norte }\end{array}$ & $\begin{array}{r}45 \\
5 \\
3\end{array}$ \\
\hline
\end{tabular}

(Fonte: ETEA, outubro de 1968.)
QUADRO X

EXPORTAÇÃO DE CASTANHA-DO-PARÁ EM QUILOGRAMAS 1965

\begin{tabular}{lrc}
\hline \multicolumn{1}{c}{ Principais Paises } & Com Casca & Descascada \\
\hline 1. Estados Unidos & 3.275 .230 & 2.171 .250 \\
2. Alemanha & 1.847 .448 & 48.210 \\
3. Inglaterra & 898.760 & 1.104 .750 \\
4. Canadá & 631.444 & 231.210 \\
5. Argentina & 122.500 & - \\
6. Itália & 30.480 & - \\
7. Austrália & 12.700 & 6.600 \\
8. México & 5.000 & - \\
9. Irlanda & - & 15.300 \\
\hline
\end{tabular}

(Fonte: PANDOLFO.)

QUADRO XI

EXPORTAÇAO GLOBAL DE CASTANHA-DO-PARÁ

\begin{tabular}{ccc}
\hline Ano & Toneladas & US\$ 1,000 \\
\hline 1963 & 25.194 & 8.882 \\
1964 & 24.185 & 10.421 \\
1965 & 19.911 & 11.597 \\
1966 & 30.323 & 15.083 \\
1967 & 19.975 & 10.130 \\
1968 & 36.172 & 14.969 \\
\hline
\end{tabular}

(Fonte: IBGE, 1966, e FIBGE, 1969.)

É preciso dizer, depois disso tudo, que ainda novos personagens têm surgido ultimamente na região de Marabá. Um deles é o pequeno agricultor de terra firme, que entra em cena a partir da década de 50. Outro vem sendo, mais recentemente ainda, o pecuarista vindo de fora. É deles, basicamente, que iremos tratar nos próximos capítulos. 


\section{A FRENTE AGRÍCOLA}

Há uma tendência a identificar o início do soerguimento econômico da Amazônia com a construção da Belém-Brasília, os incentivos fiscais, a criação da Superintendência do Desenvolvimento da Amazônia (SUDAM) etc. Trata-se de uma meia-verdade, já que nenhuma dessas medidas, por si, teria efeito considerável, não fosse a existência de certas precondições que vinham lentamente amadurecendo. Apesar do peso crescente das iniciativas do Estado no processo de desenvolvimento, o fato é que elas só se tornam em geral viáveis quando carregadas do senso de aproveitamento de determinados movimentos sociais. É o que ocorre com a Belém-Brasília, e, também, com a própria construção de Brasília, que por desinformação continuam a ser identificadas frequentemente com um esforço absolutamente heróico de ação sobre um deserto; o que, aliás, é contestado pelo incremento demográfico regional ocorrido na década de 50, tal como vimos na Introdução. E por assim ter sido é que de fato se justificam e têm condições de ganhar vida. Embora o desenvolvimento das forças produtivas ocorrido nos últimos anos se dê dentro de um modo determinado de articulação entre o político e o econômico que certamente não é caracterizado pelo puro espontaneísmo econômico, mas onde a iniciativa política seguidamente comanda o processo, tal no entanto só pode se dar eficazmente respeitados certos limites. Afinal, falava-se na transferência da Capital Federal desde 1822, e não há de ter sido por um mero acaso que ela se deu em nossos dias, e não antes.

\section{As Novas Frentes}

Nas duas pontas do que seria mais tarde o traçado da Belém-Brasília, o início da movimentação econômica maior data do final da década de 30 e começo da de 40. Na ponta do Sul, semiabandonada a uma pecuária ultraextensiva desde a decadência da mineração, liga-se à colonização do Vale do São Patrício, passando por cima das áreas estagnadas, pela ação de uma frente agropecuária que se constitui num prolongamento mais fraco do que no Norte do Paraná da expansão da agropecuária paulista e mineira.

Apesar de ser em grande parte espontâneo, o movimento, já aí, beneficia-se da ação governamental, a que não é estranha a pregação da
Marcha para o Oeste, muito em voga durante o Estado Novo ${ }^{1}$. É grandemente facilitada pela abertura de estradas, especialmente a que alcançaria Ceres, construída por Bernardo Saião, e que se constituiria mais tarde no trecho inicial da Belém-Brasília a partir de Anápolis. É também estimulada pela criação da Colônia Agrícola de Ceres, e, mais remotamente, pela transferência da capital do Estado para Goiânia, e a organização da Fundação Brasil Central.

Na Amazônia Oriental, liga-se o início do soerguimento econômico, por um lado, a um certo crescimento agrícola, iniciado na década de $30 \mathrm{com}$ o cultivo da juta, da malva e da pimenta-do-reino, onde é significativa a participação de colonos japoneses, particularmente em Tomé-Açu. Deu-se basicamente na zona Bragantina e no Baixo Amazonas.

Por outro lado, liga-se também a uma revalorização da borracha amazônica e, também, de minerais considerados estratégicos, no decorrer da II Guerra Mundial, e que conhecerá seus prolongamentos, particularmente no Amapá.

Na zona do Itacaiúnas, já nos referimos à exploração do cristal de rocha. Mais tarde, tal como no Acre, no Solimões e no médio Amazonas, zonas também tradicionalmente ligadas à extração vegetal, teremos no Itacaiúnas o desenvolvimento da pecuária, que se acrescenta ao crescimento do rebanho já anteriormente existente no eixo Manaus-Santarém².

Todavia, houve outra fonte de mudanças na zona do Itacaiúnas ${ }^{3}$. Prende-se ao prolongamento da expansão de pequenos agricultores

${ }^{1}$ Ver, a propósito, Cassiano RICARDO, A Marcha para o Oeste, Livraria José Olympio Editora, 1940 (republicado em 1970).

${ }^{2}$ No caso do Acre e do Solimões, o desenvolvimento da pecuária, afora as possibilidades de exportação para os países vizinhos, deve ter-se devido, inicialmente, não à proximidade relativa de um mercado comprador, como no Itacaiúnas, mas ao crescimento demográfico local aliado à enorme distância dos mercados abastecedores e à nova involução da atividade seringalista depois da Guerra. No médio Araguaia, especialmente no Norte de Mato Grosso, onde tem provocado choques com posseiros, prende-se à relativa proximidade do Centro-Sul e à penetração de grandes capitais, especialmente paulistas, antes mesmo da Belém-Brasília, e que iriam se aproximando de Conceição do Araguaia.

3 É interessante assinalar como a perda de posições no mercado internacional parece ter estimulado, particularmente em Caxias, o desenvolvimento de um parque têxtil voltado para o mercado regional, que chegou a ser o terceiro do país, e que entrará posteriormente num processo de decadência que praticamente terá o seu desenlace na década de 50 deste século. 
nordestinos ocorrida no Maranhão e que acabou penetrando no Pará por essa zona na década de 50. Aos poucos suplantaria um movimento de nordestinos que se deu, sem representar um avanço contínuo, na direção do baixo Amazonas, concentrando-se em Santarém, Alenquer, Monte Alegre e Januacá (DIAS, 1969, p. 22).

\section{O Avanço no Maranhão}

Já vimos, no capítulo 3, como a frente pecuarista de origem baiana, em Grajaú e Barra do Corda, alcançara, já na primeira metade do século XIX, as orlas dos chamados vales úmidos do Maranhão - o Mearim, o Grajaú, o Pindaré e o Turiaçu, tal como, a Oeste, a beira da floresta amazônica em Imperatriz. O gênero de pecuária praticado e o receio de tribos indígenas impediu que fossem plenamente ocupados.

Por outro lado, o avanço propriamente maranhense, a partir do litoral, da civilização do babaçu, do arroz e do algodão, até as primeiras décadas deste século só alcançava praticamente o curso inferior e médio do Itapicuru e a porção inferior do Turiaçu e do Pindaré, até onde se fora pela existência de planícies e graças ao cultivo de algodão relativamente longe do litoral. Algumas cidades existentes nessa linha, aproximadamente paralela à costa a uma distância de 200 a $300 \mathrm{~km}$ por esta altura e mais a Leste, na direção do Parnaíba - como Pindaré-Mirim, Bacabal, Pedreiras, Codó e Caxias, haviam regredido ou estacionado relativamente com a queda do algodão no mercado internacional após a Guerra de Secessão nos Estados Unidos e com a entrada do algodão egípcio no mercado europeu. Isso levou, inclusive, a uma expressiva redução nas unidades de produção.

Por volta das primeiras décadas do século, iniciou-se uma penetração de nordestinos no Maranhão, em busca de terras e fugindo das secas e das dificuldades de colocação da mão-de-obra no próprio Nordeste. Atravessam o Parnaíba em Teresina e Floriano, e a princípio vinham também por mar. Praticavam uma agricultura de subsistência e, em graus variáveis, a do arroz com linalidades comerciais. É uma hipótese plausível que a decadência da exploração da borracha amazônica tenha estimulado o movimento nessa direção a partir de 1920, o que evitará a interrupção do fluxo de nordestinos que já estava se dando e lhe dará uma nova forma que constituirá um marco significativo nas transformações da exploração agropecuária no Brasil. É também o que emprestará ao Maranhão sua feição atual tão marcadamente agrícola.

O movimento inicial tendeu a repassar as áreas decadentes das orlas dos vales, trazendo-lhes um sopro de vida. A isso se acrescenta, após 1930, com a descoberta de ouro e a pacificação dos índios Urubu, a penetração também nas áreas efetivamente novas e de floresta dos vales, a que se juntam, então, os próprios nativos do Maranhão. Aos poucos estabelecemse determinadas rotas de penetração, cada uma das quais tendendo a ser preferida de acordo com a área de origem dos migrantes. Um dos ramos da frente nordestina, após ultrapassar Caxias, avança no sentido noroeste e, segundo ANDRADE (pp. 82/84), em 1920 estará a oeste de Codó, atingindo Pedreiras em 1940, Bacabal em 1950 e o Arraial de Santa Inês em 1957, ponto de passagem para o Turiaçu após ultrapassado o Pindaré. Em 1959 forma-se Bom Jardim, em 1960 atinge-se Chapéu de Couro e em 1961 o posto do Alto Turi, às margens do Turiaçu, buscando-se, então, o Gurupi. Quando a SUDENE resolve realizar uma política de povoamento dos vales úmidos verificará que em boa parte ele já estava se dando. O Segundo Plano Diretor falará na existência já de aproximadamente 50 mil pessoas na área do projeto, entre Pindaré-Mirim e Alto Turi ${ }^{4}$. Os esforços para se criar uma infra-estrutura que permita aumentar ainda a base populacional encontrará dificuldades no próprio tipo de agricultura predatória praticado, em certo sentido o mais racional do ponto de vista do agente enquanto houver abundância de terras adiante e escassez de capital.

A partir de Floriano, um segundo ramo se dirigirá para Oeste, para Pastos Bons, São Raimundo das Mangabeiras, Riachão, Carolina etc., praticando preferencialmente a pecuária. Um terceiro ramo, saído de Caxias, buscará o Sudoeste. Uma parte se dedicará à pecuária, na direção de Barra do Corda, mas também na direção do Tocantins, nos municípios de Carolina e Imperatriz. Outros procurarão as matas ciliares dos altos cursos do Mearim, do Grajaú é do Pindaré (ANDRADE, p. 84).

Em Imperatriz, voltar-se-á a encontrar a floresta. A parte do município preferencialmente ocupada a princípio será á de campo. Porém, a proximidade do novo tipo de fronteira agrícola nas matas ciliares a Leste, que, além do mais, pelo seu modo de exploração vai aos poucos diminuindo

\footnotetext{
${ }^{4}$ Ver SUDENE.
} 
a capacidade de assimilar maiores contingentes, como também a dificuldade da pecuária tradicional absorver muita mão-de-obra, irá estimular o início do avanço para a floresta amazônica. Tal como já ocorrera em outros lugares a partir do final da II Guerra Mundial, a construção de uma estrada, embora precária, na direção de Grajaú (1950), aumentará o fluxo populacional, com o caminhão substituindo aos poucos nos trajetos maiores as viagens a pé e a cavalo.

Nesta etapa, o avanço da frente afetará pouco a cidade propriamente de Imperatriz, a não ser no sentido da nova estrada aumentar os contatos comerciais com Fortaleza e Recife em detrimento de São Luís. Em 1956 havia, por exemplo, exclusivamente um caminhão registrado na prefeitura. Buscar-se-á preferencialmente o meio rural, onde surgirão diversos aglomerados. Aos poucos, dos próprios vales úmidos a Leste começarão a vir migrantes de primeira ou segunda geração que já têm dificuldades de terras, e enfrentam a ação de grileiros. Juntam-se, então, aos nordestinos propriamente, maranhenses que são fruto de uma migração intergeracional, e que aos poucos predominarão, seguindo-se os piauienses. Curioso que, como sói acontecer na relação migrante-nativo, assim como ao penetrarem no Maranhão os nordestinos ganharam fama de mais trabalhadores e lutadores, embora menos "delicados", do que os maranhenses, ao penetrarem no Pará eles e, especialmente, seus descendentes, gozarão da mesma fama em relação aos paraenses do baixo Tocantins; mas, agora, identificados como maranhenses.

\section{O Avanço no Itacaiúnas}

Tradicionalmente, muitos moradores de uma ampla área do Sudoeste do Maranhão, em especial aqueles que habitavam próximo ao Tocantins, deslocavam-se para o Itacaiúnas por ocasião da safra da castanha, juntamente com moradores do Norte de Goiás e do baixo Tocantins. Aparentemente, muitos dos recém-vindos foram juntando-se a esse movimento, realizando a descida do Tocantins, em especial desde Imperatriz, para Marabá, até se tornarem maioria. As próprias características da variação anual das exigências de trabalho na lavoura o permitiam. Aos poucos, alguns foram ficando - mesmo antes de aumentar demasiadamente a pressão na altura de Imperatriz - atraídos pela abundância absoluta de terras e sua qualidade, por garimpos ou pela simples existência em geral das alternativas de trabalho. Eram como que pontas-delança da frente maranhense.

Embrenhavam-se na mata por ocasião da entressafra, para se fixar num gênero de vida caracterizado pelas atividades de subsistência e por um alto grau de isolamento que lembra, ainda, a figura do camponês marginal de que fala OBERG. Com a diferença, apenas, que em geral continuavam a alternar entre a agricultura de subsistência e o trabalho sazonal da castanha, quando não com atividades de garimpagem. À medida que a área se tornava mais conhecida por esta corrente vinham indivíduos diretamente de seus locais de origem, em geral na porção superior dos vales úmidos, apenas passando por Imperatriz.

A sobrevivência dos povoadores era facilitada pela coleta de frutos silvestres e pela abundância de caça, cuja pele buscavam vender. Por vezes empregavam-se inicialmente nas grandes fazendas que iam surgindo, mas em geral apenas o tempo suficiente para realizar uma pequena acumulação ou orientar-se devidamente. Com o tempo, os fazendeiros vão tendendo a dar preferência a um pessoal mais fixo e de quem já se tenha referências na região.

Em outros casos, a atividade inicial era de garimpagem, frequentemente só surgindo a ideia da agricultura com o esgotamento do garimpo. Mas havia, efetivamente, um corpo de ideias em torno das vantagens, sempre que possível, de trabalhar por conta própria. Por isso, ainda na castanha muitos preferiam buscar os castanhais do município, que até o final da década de 50 ofereciam algumas possibilidades, mas que vão aos poucos sendo invadidos pelos grandes patrões no seu processo de concentração, agora também com a pecuária; o que constituirá um fator de aceleramento na passagem mais decisiva às atividades agrícolas. $\mathrm{O}$ mesmo, porém, ocorre também com a colônia agrícola que se tentou em Quindangue, próximo a Marabá (ver cap. 5), hoje transformada quase toda em grandes pastagens. As dificuldades para os pequenos produtores são especialmente grandes, próximo a Marabá, e por isso mesmo é que sua atividade desenvolveu-se, de modo coerentemente marginal, em Itupiranga e, especialmente, em São João do Araguaia, mais próximo por via fluvial do Maranhão e das novas rotas. E de preferência, embora nem sempre, em terras não ocupadas por castanheiras em volume suficiente para se terem transformado em castanhais de propriedade. Apesar disso, não estarão livres 
de choques; mesmo porque, haverá exceções a essa regra, especialmente em áreas de propriedades não exploradas por ocasião da ocupação por parte dos lavradores. Em Marabá propriamente, após um surto inicial da pequena agricultura no começo da década de 50, a sua atividade cai. Existem, mesmo, trechos do Itacaiúnas que há poucos anos conheceram a presença desses pequenos produtores, e que hoje encontram-se desertos, parte deles deslocando-se para outras áreas, e parte para a cidade, que continua a crescer ${ }^{5}$.

De qualquer forma, vai-se criando uma agricultura de terra firme, que acaba por obscurecer a tradicional pequena agricultura de várzea. $\mathrm{Na}$ década de 50, como vimos na Introdução, não só a zona do Tocantins no Maranhão (que incluía Imperatriz e Montes Altos), mas, também, no Estado do Pará, a zona do Itacaiúnas, aparecem como zonas de alto incremento demográfico, juntamente com o limítrofe Planalto (Conceição do Araguaia) ${ }^{6}$. A crença de que os terrenos melhoram à medida que se afasta do rio, e o fato de que é para lá que se encontram geralmente terras desocupadas, estimula o avanço para Oeste e Sudoeste, que é especialmente significativo em São João do Araguaia, embora haja também como que uma reocupação da beira-rio, inclusive de trechos e locais mencionados por COUDREAU antes da reestruturação provocada pela exploração da borracha (como Bacurizinho, Bacuri Grande e São Bento).

Mais do que em Imperatriz, predominavam os maranhenses e piauienses, embora houvesse representantes do Ceará e, em menor número, dos outros Estados nordestinos, a que se juntavam também goianos.

O padrão usual de ocupação consistia nos indivíduos embrenharemse na mata e escolherem um sítio considerado favorável, em geral junto a um curso d'água (igarapé) ou pequena lagoa; em terreno com barro, considerado vantajoso para a lavoura e para a criação de porcos, oferecendo, ainda, material para a construção das casas; e, se possível, onde houvesse babaçu, mais abundante em São João, considerado sinal de terra boa. Estabeleciam-se com suas famílias, e realizavam sua queimada.

Por vezes o indivíduo mantinha-se extremamente isolado, a dias de distância de outro morador ou de um aglomerado, sendo extremamente

${ }^{5} 1960$ - 8.342 habitantes; $1970-14.593$ habitantes.

${ }^{6}$ Tocantins (Maranhão) - 241,7\%; Itacaiúnas $-76,0 \%$; Planalto $-81,1 \%$. valorizada a posse de um aparelho de rádio. Outras vezes, as distâncias eram menores, e em alguns casos formavam-se comunidades rurais. Essa maior ou menor proximidade dependia da existência de terra desocupada, mas também da maior ou menor homogeneidade do terreno quanto a suas qualidades e da existência próxima de um castanhal de servidão pública. Quando houvesse um sítio considerado especialmente privilegiado, havia a tendência à formação de um aglomerado.

No entanto, apesar de ser considerado desejável morar menos isolado do convívio humano, a formação de aglomerados apresentava seus problemas. Era preciso que os moradores se pusessem de acordo sobre uma série de coisas. Uma delas, por exemplo, é a criação de porcos. Os porcos tendem a invadir a roça, e então é preciso combinar que ninguém crie porcos, ou, então, que se cerquem as roças. Por vezes surgem desavenças ou desacordos, e então afastam-se, em geral numa distância de 250 a $1.000 \mathrm{~m}$.

Muitas vezes são parentes, ou pelo menos indivíduos do mesmo local de origem, que se fixam inicialmente juntos. Com a facilidade relativamente maior de comunicações nos últimos anos, por vezes em indivíduos voltam a seus locais de origem, para visitar os parentes, ou, então, depois dos trabalhos iniciais, para buscar a família. A "propaganda" que fazem por vezes faz carregar outros consigo.

À medida que um aglomerado pega, ou seja, de fato demonstra que tem condições de se expandir, e por vezes, dependendo das vias de comunicação abertas, transformar-se no local da primeira comercialização, outros moradores, que estão isolados na mata em torno, deslocam-se para lá, podendo mesmo serem esvaziados outros aglomerados menores, especialmente se estiverem bem próximos. Num momento seguinte, quando chega a poder oferecer rudimentos de instrução escolar para as crianças, surge novo e poderoso fator de polarização, que atrai famílias inteiras ou, então, que faz com que enviem os filhos para ficar com amigos e compadres. Isso, aliás, não é considerado um fardo por quem recebe as crianças dada a importância do trabalho infantil, que se inicia já por volta dos 5 anos em tarefas domésticas e que se considera educativo.

Assim, a partir de certo ponto por vezes as terras do indivíduo já não estão tão próxímas ao local de residência; mesmo porque, há as exigências da própria expansão do aglomerado, que em certos casos obrigam ao 
afastamento das roças; o que, aliás, encontra às vezes resistência da parte dos moradores mais antigos, que em gerar são superadas dado um certo interesse geral na expansão. Essa separação entre local de residência e de trabalho torna-se mais frequente à medida que chegam novos migrantes e só existem terras não ocupadas adiante. Tanto os recém-chegados quanto os antigos moradores que esgotam as possibilidades de utilização de suas primeiras terras oscilam, então, entre ficar no aglomerado ou morar junto à roça; não devido propriamente a uma tendência absenteísta, mas a uma tendência comunitária definida ainda em termos rurais. Quando podem, os moradores mais antigos colocam alguém na roça - geralmente um recémvindo - e se deslocam constantemente. Ou, então, ficam na roça e mantêm a família no aglomerado, para onde se deslocam nos fins de semana. Não raro, à medida que a frente avança, o aglomerado propriamente definha, em termos populacionais, ou pelo menos permanece relativamente estacionário, embora por vezes aumentando, pelo menos durante certo período, a sua rede de domínio através de suas funções comerciais.

$$
* * *
$$

Como já foi assinalado, existe a crença entre os participantes da frente de que os terrenos melhores não se encontram junto aos grandes cursos d'água (no caso, particularmente o Tocantins). Além do mais, e o que é mais importante, tudo o que houve de ocupação da área (e da Amazônia como um todo) em épocas anteriores prendeu-se aos grandes eixos fluviais. Essa frente demonstra o seu caráter radicalmente novo, mesmo antes do aparecimento de estradas que não se orientam mais pelos cursos d'água, pelo fato de sua referência ser o interior, onde se encontram as terras desocupadas.

Com isso vai se utilizar uma categoria extremamente interessante que é a de centro. O centro é o local onde se encontra a roça de um ou mais lavradores. E, pelas razões indicadas acima, define-se também no contexto da oposição a uma outra categoria, a beira (do rio). A beira é entendida como o lugar onde se situam os aglomerados maiores e mais antigos, ou o que poderíamos denominar de civilização. Em contraste, o centro está ligado à ideia de centro da mata; portanto próximo e em contato com a natureza não controlada pelo homem.

A beira é sem dúvida um lugar melhor para se viver dentro dessa concepção; e é, ao mesmo tempo, o lugar, entre os homens pobres, dos que querem sobreviver sem se esforçar muito: apenas pescando um peixe ou outro, ou realizando uma pequena plantação à beira do rio.

Assim, a oposição centro-beira sintetiza uma série de outras oposições através das quais a frente agrícola define a sua identidade ligada à penetração continental em oposição a uma penetração predominantemente fluvial.

$$
\begin{gathered}
\text { Centro } \\
\text { Roça } \\
\text { Predominio agricultura } \\
\text { Trabalho duro } \\
\text { Próxima à natureza não } \\
\text { controlada (mata) } \\
\text { Isolamento }
\end{gathered}
$$$$
\text { Beira }
$$

Cidade, vila

Predomínio pesca Pouco trabalho, lazer

Próximo à natureza mais controlada e conhecida

$$
\text { Contato }
$$

É de se notar que essa simples oposição de início respeita em seu conteúdo o predomínio da beira. Ou seja, é indicativa da caracterização da frente por si mesma como frente secundária, sob o domínio de toda uma estrutura preexistente que não controla.

O que vai provocar o aparecimento de um elemento de perturbação nesse esquema é justamente o desenvolvimento, a partir de alguns centros, de aglomerados maiores, por vezes chamados de rua. Deixam de ser um simples centro quando o seu crescimento exige que as roças sejam deslocadas mais para longe; seguidas, depois, pelos currais de animais.

Até então, em toda a história da área os aglomerados maiores haviam sido necessariamente da beira. Agora, temos aglomerados que, sem serem da beira, constituem um elemento de civilização surgido da própria frente, e que marca uma reorientação das mais significativas. Todavia, é provável que afora a separação entre roça e residência, o aglomerado venha a ser visto como constituindo uma beira de novo tipo: a beira da estrada.

Embora na área do Itacaiúnas ainda não tenha se formado uma efetiva rede de aglomerados maiores, com relações mais complexas entre si, como em Imperatriz, nem por isso deixaram de existir alguns que talvez exatamente por serem em menor número tiveram uma grande capacidade de polarização. Um dos mais conhecidos e importantes é São Domingos do Araguaia. Fixando-nos um pouco no seu processo de desenvolvimento, ganharemos alguma compreensão da dinâmica da frente agropecuária no 
Sul do Pará. Servirá, ainda, como ponto de referência para o exame da área em torno, inclusive de outros aglomerados.

\section{São Domingos das Latas}

A sede do atual município de São João do Araguaia, na confluência do Araguaia com o Tocantins, manteve-se estagnada, aproximando-se do tipo ideal de povoado decadente de origem colonial. A não ser por um curto surto minerador durante a Guerra, tem oferecido poucos atrativos. Sua localização, considerada boa do ponto de vista estratégico na época de sua fundação (ver cap. 3), hoje a coloca em desvantagem. Os terrenos em volta são acidentados, e, além do mais, assim mesmo os terrenos no município, que já tinham dono encontravam-se exatamente ao seu redor, o que desestimulou a penetração de novos povoadores. Mesmo como porto São João não oferece boas condições. Sua capacidade de polarização sobre o próprio município é reduzida. $\mathrm{O}$ antigo povoado de Landi, por exemplo, próximo a Marabá, pouca ligação manteve com a sede.

Em 1951 surgiu um garimpo 7 km acima de São João, mas ainda no encontro do Araguaia com o Tocantins. Esse garimpo atraiu muitos indivíduos, especialmente de Goiás, Maranhão e Piauí, mas também da própria vila de São João. Mesmo algumas figuras políticas de projeção local mudaram-se para lá, dedicando-se ao comércio, no que foram estimuladas ainda por vicissitudes da luta política. O garimpo foi de curta duração (praticamente até 1952), mas serviu para o arranque inicial que daria origem à vila de Apinagés; apesar de muitos se retirarem para os garimpos de Goiás. Embora ainda próximo a São João, por perto já havia alguma terra devoluta; mas o que a favoreceu particularmente foi o fato de seu porto ser de melhor qualidade do que o de São João. Suas casas apresentavam uma rusticidade bastante homogênea, quebrada apenas, aqui e ali, pelo estabelecimento residência de algum comerciante. Na beira do rio, inúmeras choupanas são cobertas pelas enchentes de janeiro a março e novamente levantadas quando as águas descem. Por isso mesmo, são feitas de palha, sem nenhum esforço em melhorá-las.

Em 1961 melhora-se a trilha que ligava pinagés a São João, tornando-a carroçável.

Quando do ressurgimento do município de São João do Araguaia, a 29 de novembro de 1961 (na mesma data em que é criado Jacundá, saído de
Itupiranga) ${ }^{7}$, já houve quem reinvidicasse Apinagés para sede, apesar de toda a tradição de São João. Nas eleições de 1966, ao passo que em São João votaram 243 eleitores, em Apinagés votaram 259, e o prefeito eleito foi um comerciante de Apinagés, contra a oposição do Governo do Estado ${ }^{8}$.

A decadência da navegação fluvial, particularmente a partir de 1969 (ano em que Apinagés possuía cerca de 300 casas), devido à abertura da precária estrada de 54 km entre São João e Marabá e o ramal de Marabá da Belém-Brasília, irá afetar Apinagés negativamente, embora as ligações com Imperatriz continuem a ser feitas de barco até a abertura da Transamazônica.

$$
* * *
$$

Desde o esgotamento do garimpo em Apinagés, diversos indivíduos, em geral maranhenses e piauienses, foram penetrando na mata, afastando-se do rio, e dedicando-se à agricultura. Durante a safra coletavam castanha, seja para os patrões, seja para si mesmos em castanhais do município ou às escondidas em castanhais alheios. Iam, também, abatendo alguma caça, de cuja carne se serviam, reservando as peles para a exportação. Permanecia um padrão variado de alternativas, que reduzia a ociosidade sazonal e deve ajudar a explicar o pouco desenvolvimento de um artesanato doméstico ${ }^{9}$. A eles foram se reunindo outros maranhenses, piauienses, cearenses, goianos etc., que já vinham diretamente de outras áreas, em geral de seus próprios Estados. Eram poucos, e em geral muito dispersos; por vezes a muitas horas de distância do morador mais próximo. Em alguns casos, algumas famílias se reuniam.

Plantavam milho, arroz, mandioca, feijão, fava. Às vezes mantinham uma pequena criação de porcos e galinhas. A produção era quase toda para a subsistência, vendendo-se eventualmente alguma coisa para os castanhais, os garimpos ou para o consumo de Marabá; tudo com muita dificuldade,

${ }^{7}$ Anteriormente houvera uma tentativa frustrada de transformar São João do Araguaia do município em 1957, que só durou dez meses.

${ }^{8}$ Esta foi a segunda eleição após a criação do município. O primeiro prefeito foi um grande fazendeiro de Marabá, um dos que mais estenderam as suas terras na direção de São João, e filho do antigo prefeito de Marabá cassado em 1964.

${ }^{9}$ Aparentemente, o desenvolvimento maior do artesanato doméstico tradicional restringe-se predominantemente de fato às áreas mais antigas e de campo. É assim que em Carolina, próxima à faixa limítrofe, ainda se encontra um artesanato relativamente próspero. 
dadas as distâncias e a quase ausência de meios de transporte e de comunicação. Quase tudo era feito a pé, pois mesmo os burros escasseavam.

Um desses indivíduos foi Serafim Canafista da Silva, humilde lavrador piauiense que foi o primeiro a se estabelecer, a $18 \mathrm{~km}$ de Apinagés, no local onde hoje se encontra São Domingos. Eis a sua história:

O pai era cearense de Sobral. Migrou para São Miguel, no Piaú, onde nasceu Serafim. Lá, na década de 20, trabalhava como agregado numa fazenda. Era difícil colher os legumes (cereais) por causa do gado. Pagava um dízimo. Quando precisava, o dono juntava os moradores para algum trabalho. De vez em quando dava um presente para o patrão. O patrão era bom, mas o genro que o sucedeu era ruim. Além do mais, a terra estava cansada.

Saiu de lá em 1929. Morou um pouco adiante de Codó, no Maranhão, uns três anos, mas lá as condições também não eram boas. Foi para o Mearim; perto de Pedreiras, onde estabeleceu-se até 1947. Antes lá havia muita terra, mas a mata foi acabando e foram surgindo os grileiros. Foi para Boa Vista (Tocantinópolis), onde ficou dois anos; mas lá era tudo encapoeirado (ou seja, a vegetação já era aquela que cresce depois da queimada). Foi para Imperatriz, onde se estabeleceu num centro então chamado Carros, hoje São Raimundo. Acha que embora houvesse muita mata em Imperatriz, o legume não dava bem. Depois de dois anos, veio até o Pará para "arreparar". Esteve em Apinagés na época do garimpo, mas não gostou. Só havia pedra. Seguiu adiante, com um filho e um primo.

Encontrou algumas barracas abandonadas de castanheiros junto a um igarapé. Era 1951. O local era próximo do castanhal de um certo José Miranda, mas como ele não tinha ainda a documentação, outros tiravam também castanha. No mesmo local, uns dez anos antes, aparentemente ainda se extraía borracha. Encontraram muitas latas espalhadas etilo chão, deixadas pelos castanheiros, e o sítio acabaria ficando conhecido como Das Latas. Encontrava-se ainda na área cerâmica indígena espalhada; donde se conclui já ter havido uma aldeia de índios no local ${ }^{10}$.

${ }^{10}$ A atual aldeia dos índios Suruí situa-se a cerca de $50 \mathrm{~km}$ de São Domingos. Os índios eventualmente aparecem em São Domingos para comerciar. Ver LARAIA em LARAIA e MATTA.
Serafim botou roça e foi buscar a família, que ficara em Imperatriz, o que ocorria em muitos casos como este. O primo não ficou. De início plantava só para comer, e logo depois para alimentação dos seus parentes irmãos, primos, cunhados etc. - que foram chegando. Restava um pouco de arroz que vendia muito barato em Apinagés, onde também comprava alguns mantimentos, como querosene, sal etc., que vinham de Marabá. Os outros começaram a chegar em 1953. Esses parentes, bem como outras pessoas que foram chegando, já eram nascidos no Maranhão, no Pindaré e no Mearim. De início vieram muitos de Pindaré-Mirim, trazidos pelas notícias levadas pelo compadre Chico, o segundo morador. Em 1969, Serafim devia ter cerca de 80 pessoas aparentadas em São Domingos. O número se tornou especialmente grande pelo fato de sua mulher ser também sua prima.

$* * *$

As datas fornecidas por Serafim coincidem com o que se sabe do avanço da frente no Maranhão tal como o resumimos no início do capítulo. Aparentemente, do lado do curso médio e inferior dos rios maranhenses, à medida que a frente era obrigada a um novo avanço, uma parte do seu contingente se destacava do rumo geral, orientado para o Norte, e se dirigia para Oeste. Foi o que fez Serafim no final da década de 40, quando a frente começava a ultrapassar o Mearim, e, alguns anos depois, os seus parentes e companheiros saídos já em boa parte do Pindaré, e que não escolheram o avanço para o Turiaçu, o que já ia acontecendo com contingentes maiores na década de 50 .

O Mearim, apesar de sua decantada fertilidade, continuará, numa espécie de corrente migratória preferencial, a fornecer, juntamente com o Pindaré, boa parte dos moradores de São Domingos das Latas, nome dado ao aglomerado por Frei Gil Gomes, frade dominicano de Marabá. Aparentemente, os municípios maranhenses que mais fornecerão contingentes para São Domingos são Vitorino Freire e Lago da Pedra, ambos no Baixo Mearim, além de Pedreira, Bacabal etc. É de se lembrar, a propósito, que ainda no Mearim a frente tendeu, por um sub-ramo, a descer o rio, à medida que outro sub-ramo o ultrapassava, o que deve explicar a continuação da presença de novos migrantes saídos ainda do Mearim.

Eis algumas das localidades do Maranhão mais mencionadas como local de origem em São Domingos: 
1. No Baixo Mearim: Bacabal, Lago da Pedra, Lima Campo, Olho d’Água das Cunhãs, Pedreiras, Vitorino Freire.

2. No Pindaré: Pindaré-Mirim, São Pedro do Pindaré, Santa Inês.

3. No Itapecuru: Alto Alegre, Caxias, Codó, Coroatá, Rosário. A zona do Itapecuru, que sofreu novo incremento migratório depois da II Grande Guerra (ANDRADE, p. 90), é seguidamente denominada de sertão, o que pode estar associado ao fato do tempo da ocupação inicial já ser mais distante.

4. No Alto Parnaíba: Pastos Bons.

Depois dos maranhenses da frente, responsáveis por cerca de $80 \%$ do total, seguem-se os piauienses, que são cerca de $10 \%$. Vem de muitas zonas do Estado, sendo um dos municípios mais mencionados São Pedro do Piauí, no Médio Parnaíba. A seguir, com contingentes menores, seguem-se cearenses, goianos (do Norte), paraibanos, pernambucanos etc. Só há um homem adulto considerado paraense, que é natural de Marajó. Aliás, o que é bem significativo, quando se fala em Pará na área, em geral está-se referindo apenas àquilo que se estende de Tucuruí para baixo ${ }^{11}$.

Em 1956 havia cerca de 14 casas em São Domingos. É a partir daí que se acelera o seu crescimento, não só atraindo novos migrantes, como também muitos moradores anteriormente estabelecidos na mata em volta. Em 1958, serão cerca de 30 casas, em 1960, 60, e em 1961 aproximadamente 90 , o que devia corresponder a uma população de çerca de 500 pessoas.

Uma parte da população se nucleava em torno de uns dois ou três grupos familiares extensos. O restante, em geral encontradiço entre os chegados menos remotamente, eram indivíduos que se estabeleciam com suas famílias nucleares, alguns mantendo-se durante muitos anos sem ter notícias de pais e irmãos. Por vezes outros parentes iam chegando. As relações de compadrio substituíam, em parte, as famílias ausentes ${ }^{12}$. Muitos

${ }^{11}$ Para baixo na formulação regional, já que a referência; bem concreta, continua a ser o curso do rio Tocantins.

${ }^{12} \mathrm{O}$ compadrio de alma (batisado de filho) parece se estabelecer ou entre iguais (horizontal) ou seguindo uma escala na estratificação social em que cada um busca para compadre alguém em posição um pouco melhor. Só em alguns casos verifica-se a existência de um nítido compadrio vertical. As parteiras são consideradas comadres das mulheres que assistem não tinham família ou não voltavam para buscá-las, e acabavam constituindo nova família na própria área.

Traziam consigo, porém, particularmente do Maranhão, muitas crenças e costumes, como a guarda dos dias santos sob pena de possível castigo, as práticas relativas a tabus alimentares ${ }^{13}$, ao resguardo ${ }^{14}$, à

no parto. Existe uma forma de compadrio mais informal, que é o compadrio de fogueira, em geral utilizado por pessoas mais jovens e solteiras. Há casos, aliás, também de casamento de fogueira, utilizado por pessoas já casadas anteriormente.

Os tabus alimentares giram em torno da noção de alimentos reimosos, ou seja, alimentos que ofendem o organismo, que tendem a fazer com que o organismo reaja provocando uma doença, manifestando doença a que se estava predisposto ou piorando doença já existente. Há alimentos mais e menos reimosos, e aqueles que são absolutamente não-reimosos. Não existe uma proibição absoluta contra os alimentos reimosos. Todavia, eles devem ser utilizados com cuidado e sem exageros. Tornam-se tabu quando o indivíduo está doente, para a mulher menstruada ou em período de resguardo, ou, então, a combinação de alimentos que isolados já são acentuadamente reimosos. Em muitos casos, a noção de reimosos e nãoreimoso parece ligada à ídéia de sujeira e limpeza, quer no que diz respeito aos hábitos de um animal, quer quanto ao fato de ser da mata ou doméstico, quer quanto a suas atividades sexuais, quer quanto à cor ou aparência do alimento.

Entre os alimentos reimosos, contam-se: as carnes de caça; carne de porco; a galinha d'angola (angolista ou capote); galinha de penas arrepiadas ou achatadas, crista embolada ou pescoço pelado; os peixes grandes e/ou de couro (como o pirarucu); diversas frutas (lima, limão, laranja, bacuri, açaí, jaca, mamão, ananás, carambola, manga etc.), especialmente as consideradas azedas.

O bacuri, o ananás, o açaí e a manga não podem ser misturados com ovos, nem com outra fruta, especialmente quando azeda. $O$ bacuri também não pode ser misturado com leite, nem o açaí com limão ou cachaça. Em alguns casos, essas proibições se ligam à cor resultante da mistura, tal como no caso do bacuri com ovos, que se torna escuro, e o açaí com limão que se torna encarnado, julgando-se que queima o sangue.

$14 \mathrm{O}$ resguardo dura de 30 a 40 dias e é, em contraposição à gravidez, durante a qual os cuidados não são muitos, a situação mais crítica em matéria de tabus alimentares e outras prescrições. Durante esse período, a mulher, a fim de não quebrar o resguardo, não pode levar nenhum susto, discutir, brigar, pegar peso, pegar calor, ter relações sexuais ou espantar-se; e deve ingerir somente alimentos claramente não-reimosos, como: frango capado ou pinto da primeira pena, farinha branca, feijão branco, peixes pequenos e sem couro (ex.: traíra, pacu, tucunaré) etc.

Geralmente só se pode tomar banho cerca de 15 dias depois do parto. Algumas mulheres ainda conservam o costume que está caindo em desuso de durante o resguardo usarem algodão no ouvido, andarem calçadas de meia e com a cabeça amarrada com um pano.

A quebra do resguardo provocaria febre, dor de cabeça e prostração, podendo ocasionar a loucura ou a morte.

Após o período propriamente de resguardo, ainda se deve evitar durante mais tempo, que por vezes ultrapassa um ano, os alimentos especialmente reimosos. 
medicina popular em geral, ritos religiosos afro-índio-brasileiros realizados em terreiros denominados terecôs, a crença em seres fantásticos da mata como o copelobo (um índio que ao se tornar velho fica todo coberto de pelos e passa a alimentar-se de seres humanos), a crença no mau olhado ${ }^{15} \mathrm{e}$ no olho ruim ${ }^{16} \mathrm{e}$ a de que as pessoas que cometem incesto viram monstros. Somente uma cuidadosa pesquisa comparativa revelaria até que ponto essas crenças e costumes se transformam ou se enfraquecem com a migração; à primeira vista parecem se manter em grande parte, por vezes incorporando novos elementos.

É extremamente comum os indivíduos de ambos os sexos viverem maritalmente com pessoas diversas no decorrer de suas vidas. É aceitável, em geral, que o homem venha a viver com uma mulher deflorada ou abandonada (sendeira), sendo considerado o pior nesses casos ser enganado. Todavia, acredita-se preferível, no caso de um homem que ainda não seja velho, não se casar com uma mulher que não seja virgem ${ }^{17}$. De qualquer maneira, o que é raro é encontrar-se um homem sem mulher,

${ }^{15}$ A crença no mau olhado, que provoca o quebrante, parece ligar-se à representação e tentativa de controle da força destrutiva da inveja, que pode ser inconsciente (já que a pessoa que põe o mau olhado não deseja necessariamente o mal) e que pode partir até de familiares do indivíduo afetado (ex.: a mãe pondo o mau olhado no filho recém-nascido). Também faz aproximar admiração extremada e inveja. Em geral refere-se a posses alheias ou crianças; ou seja, àquilo que possui a qualidade de bonito ou novo. A pessoa que fica parada, olhando demoradamente para alguma coisa ou criança pode estar pondo o mau olhado. Quando um vizinho insiste muito em comprar alguma coisa, seguidamente o dono acaba vendendo para evitar o mau olhado; se a situação se repete, pode vir até a se mudar.

${ }^{16}$ Certas pessoas teriam algumas propriedades, que nada têm a ver com o bem e o mal, e que são, por exemplo:

a) se são vistas ou ouvidas por quem está fazendo sabão, o sabão não cola:

b) se são vistas ou ouvidas por quem está fazendo óleo, o óleo seca;

c) se são vistas ou ouvidas por quem foi mordido por cobra, a pessoa morre;

d) se uma cobra pica uma pessoa dessas, é a cobra que morre; se passa por cima de uma cobra, ela também morre.

Por causa dessa última qualidade, as mulheres gostam de ir lavar roupa no rio com uma mulher de olho ruim para ficarem protegidas contra cobras. Da mesma forma, há casos de fazendeiros que chamam uma pessoa dessas para livrar o seu pasto de cobras quando estas estão matando o seu gado.

${ }^{17}$ Como explicou um entrevistado, expressando uma noção de poluição social: "No homem nada pega, a não ser o roubo; ele pode cair num barreiro que depois de limpo é o mesmo homem. Mas a mulher é feito o leite: qualquer ponto de sujeira toma conta e estraga tudo". sendo reconhecida a grande necessidade de se ter uma mulher para poder trabalhar $^{18}$

Conflitos com donos de castanhal. Nos primeiros tempos havia notícias periódicas de que o requerente ao castanhal José Miranda - iria desalojar a todos. Não que o sítio exato onde se encontrava São Domingos estivesse dentro do castanhal, mas é o que ocorria com boa parte das terras que iam sendo cultivadas próximas ao local, especialmente na direção de Apinagés. Como havia, porém, interesses políticos de permeio, alguns chefes políticos, que iam indicando representantes seus no local, apoiavam a população de São Domingos. O clímax da crise deu-se numa madrugada de novembro de 1958, quando tiveram notícia de que o requerente se aproximava com trinta homens e um agrimensor para demarcar as terras. A população de São Domingos tomou medidas de guerra, e enquanto alguns ficavam no povoado com as mulheres e crianças, a maioria foi ao seu encontro, numa ação conjunta que se aproxima da caracterização de uma situação de comunidade fechada, na expressão de WOLF, e que não é das mais típicas para o meio rural brasileiro. A meio caminho entre São Domingos e Apinagés, onde em 1969 já haveria um povoado de quarenta casas (Santa Luzia), fizeram-no interromper o serviço e retroceder.

Posteriormente, depois de certo período de indecisão, em que não se sabia se São Domingos acabaria, como em outros casos conhecidos, toda essa pressão dos novos contingentes de agricultores fez com que a prefeitura comprasse esse castanhal, bem como dois outros para além de São Domingos, para entregá-los ao povo. É possível que tenha sido também, para os homens da situação, uma maneira de afastar concorrentes, além de deixar aberta a possibilidade de retomada para si próprios dos castanhais. É, de fato, o que ocorrerá com um castanhal do município, que será vendido mais tarde à mãe do prefeito, obrigando à retirada de diversos lavradores que lá já haviam se estabelecido - embora em menor número e com menos força do que os que ocuparam o primeiro castanhal - sem nenhuma indenização por roças e pastos. Atendia, porém, ao mesmo tempo, a um interesse comercial e político de que aumentasse a população do município.

\footnotetext{
${ }^{18}$ Quando é abandonado pela mulher, que fugiu com outro ou que caiu na vida, o que não é
} raro, o homem logo depois vai procurar outra. 
Outros casos surgirão de conflitos entre lavradores c donos de castanhal, embora não tantos ainda quanto os casos de grilagem no Maranhão. Em geral os lavradores são obrigados a se retirar sem nenhuma indenização pelas benfeitorias. No caso, porém, de aglomerados que têm tempo suficiente para se desenvolver, como São Domingos, sua importância crescente por vezes torna impossível uma medida dessas, e os grandes interesses, que por sua vez também entram em choque entre si, terão de buscar expedientes mais sutis c demorados para realizar o seu esforço de concentração; ao mesmo tempo que buscam aproveitar o mercado criado por esses próprios aglomerados.

A violência. Nos primeiros tempos, São Domingos era considerado "lugar brabo". Não é incomum nessas regiões encontrar-se indivíduos foragidos da justiça, e muitos de fato assumiam o papel de arruaceiros. As ligações da área com a garimpagem em Apinagés aumentava o número de aventureiros. Muitos não moravam propriamente em São Domingos, e sim nos arredores; mas lá ê que em geral surgiam os problemas. Um informante, referindo-se ao mais conhecido deles, dizia: "Quando Adelino bebia, todo mundo fechava as portas com medo dele".

Pelo que se diz, esse clima desestimulava a muitos de se fixarem em São Domingos. Apesar de tudo, no entanto, São Domingos crescia, e estabilizava, o que devia levar a uma certa redução nos aspectos mais abertos da violência sem objeto. É interessante que essa redução começa a se dar exatamente depois do pior caso, que ficou célebre como o do Pau da Brigada ou da Matança, em 1961, onde pela primeira vez há uma reação maior, e que redundou em seis mortos e vários feridos. A partir daí, chamase mais a atenção para o problema, há a interferência de autoridades policiais de Marabá, e os elementos considerados mais perniciosos se retiram. $\mathrm{O}$ que não evita que nas relações pessoais eventualmente dêem-se explosões de grande violência, em geral provocadas por bebedeiras e casos de mulher, ou por desacordos nos negócios (por exemplo, em cobranças de dívidas, especialmente de arroz comprometido antes da colheita) ou na política; sendo que as considerações familiares, quando se tornam relevantes, dizem mais respeito às facções que se formam. Não é raro ocorrerem crimes de morte e dificilmente o criminoso é mantido preso, apenas retirando-se da região; especialmente quando existem conotações políticas, quando então é protegido pelos chefes de sua facção.
A estrada. No final desse mesmo ano de 1961, pouco depois de melhorada a trilha que ligava São João a Apinagés, empreende-se o mesmo esforço na trilha entre Apinagés e São Domingos, numa distância que é mais do dobro, e afastando-se do rio. Trata-se de um marco na história do povoado. Mais uma vez, combina-se um pequeno estímulo de políticos e homens de negócios de fora com o esforço da comunidade. No início da abertura da estrada, foi relativamente reduzido o número dos que pegaram na enxada, não tendo havido nenhuma decisão de assembléia; porém, aos poucos, os demais foram se entusiasmando, e ao penetrarem triunfalmente em Apinagés eram 60 homens de São Domingos. A viagem que se fazia em quatro horas a cavalo e em muito mais a pé (o que era o mais comum, pois havia poucos animais), passou a poder ser feita em quarenta minutos de carro. A Prefeitura de Marabá doou um caminhão, e dessa maneira aumentou de muito as possibilidades de escoamento da produção. Aumentou também o poder de polarização de São Domingos, pois os moradores da mata próxima, que antes comercializavam com dificuldade diretamente com Apinagés, passaram a fazê-lo através de São Domingos; bem como as vantagens relativas de quem veio a ter meios para adquirir ou utilizar-se, de uma viatura. Por essa época, São Domingos já não era mais um simples centro.

$\mathrm{O}$ excedente ainda era muito reduzido, e em boa parte ficava mesmo na área - nos garimpos e castanhais - aumentando aos poucos o volume para Marabá. Todavia por essa época a Belém-Brasília já alcançara Imperatriz e aumentara o tráfego de rio entre Imperatriz e Marabá, passando por Apinagés, trazendo mercadorias do Sul. Abria-se a possibilidade de novos mercados, imensamente mais amplos do que o regional, e de outros pólos de atração.

Os dados do Censo de 1960 revelam algumas diferenças interessantes no significado, naquele momento, da pequena produção agrícola em Imperatriz e Marabá (que incluía São João do Araguaia). Ao passo que apenas cerca de 30\% (1962) do total do pessoal ocupado na agropecuária (5.353) no município de Marabá era composto de responsáveis pelos estabelecimentos e os membros não-remunerados da família, em Imperatriz já alcançavam cerca de $75 \%$ (6.632) do total, que também já era maior (8.715). 
Os pequenos comerciantes locais. Tal como na história de Marabá, também em São Domingos os comerciantes, em ponto menor, foram de muita importância. Em geral eram indivíduos que mantinham relações privilegiadas comerciais e/ou políticas com figuras importantes de Marabá, e serviam de mediadores. Em São Domingos chegaram a ser cerca de 15 indivíduos que, embora apoiando-se no comércio, a partir daí, tal como ocorreu em Marabá, infiltraram-se na produção, por vezes comprando as benfeitorias de outros, e transformando-se como que numa camada superior de camponeses remediados. Somente um desses indivíduos em São Domingos não teve no comércio o seu apoio principal, embora não deixasse de estar presente.

Diversos deles iniciaram com o comércio da castanha. Na década de 50, os castanhais do município ainda tinham certa importância, especialmente menos próximo a Marabá, o que iria diminuindo com as invasões, tanto da parte de donos de castanhal e fazendeiros, quanto da parte de lavradores com o aumento dos contingentes populacionais. Esses homens, mediante crédito conseguido com comerciantes e grandes donos de castanhais em Marabá - os seus patrões ${ }^{19}$, aviavam quem ia buscar castanha em terras do município (tornando-se também patrões), compravam a castanha coletada, em geral na folha, e revendiam aos seus financiadores em Marabá, o que era uma forma indireta destes estenderem o seu controle mesmo sobre os castanhais livres. Alguns acabaram fixando-se em São Domingos, de onde partiam muitos dos que se dedicavam à coleta, e foram ampliando as suas atividades de comerciante-financiadores, inclusive vendendo-no varejo. Em geral mantinham as suas ligações em Marabá, que muitas vezes extravasavam da esfera comercial para a política, servindo como cabos eleitorais e representantes locais.

Em geral é dentre esses indivíduos, colocados na contraditória posição de mediadores entre a massa dos moradores da área e os seus contatos externos, que surgem as lideranças políticas locais. Homens que inicialmente agiam como simples representantes de políticos de Marabá, São João e Apinagés buscam ganhar maior autonomia pessoal em sua área.

${ }^{19} \mathrm{Na}$ região, patrão é fundamentalmente aquele que dá crédito, aquele que avia, seja em que nível for. Assim se estabelece uma cadeia de patronagem, que em geral é bem flexível, um indivíduo podendo ter mais de um patrão e, podendo variar de ano para ano. Não interessa que a dívida aumente muito, mas uma pequena dívida muitas vezes é desejável, pois serve para manter a relação.
Isso provoca uma crise nas relações com os políticos dominantes, que buscam "cortar as suas asas". Em alguns casos, o resultado é a 'perda de posição do pretendente; em outros, quando é bem sucedido em ver reconhecido o seu "poder, leva a um novo entendimento posterior em novas bases. A política é vivida muito intensamente em nível local, já tendo se registrado várias mortes entre partidários modestos de adversários que muitas vezes mudam de posição e celebram acordos. Em geral o interesse político está diretamente ligado à defesa de interesses econômicos, como em questões de terras, preços de mercadorias que dependem de tabelamento, impostos, estradas etc. Os comerciantes locais e camponeses remediados refletem em suas ações a sua posição ambígua, em face das ligações, por um lado com a elite de Marabá, e por outro com a massa de camponeses de São Domingos, cujos interesses muitas vezes são obrigados a defender, particularmente quando se confundem com os seus ${ }^{20}$.

Aos poucos, afora a venda de mercadorias no próprio povoado e para os moradores da mata, a que foram se dedicando, esses comerciantes iam fazendo pequenos empréstimos para quem ia fazer roça e precisava de algum dinheiro até a colheita (por exemplo, para pagar um braço que lhe ajudasse durante certo tempo). Outras vezes o empréstimo era diante de algum imprevisto, como doença, que é um dos itens que mais sobrecarrega o orçamento de uma família de lavradores. Quando alguém resolvia voltar para o Maranhão ou seguir para outro lugar, por "não ter se dado bem" (o que nunca deixou de ocorrer em pelo menos $5 \%$ dos casos), ele se prontificava a comprar as benfeitorias, o que para o indivíduo pra negócio, a fim de não perder tudo. Diz um deles: "Quando alguém está querendo ir embora, para agradá-lo compro uma glebazinha".

$\mathrm{Na}$ verdade seu crescente papel de financiadores da produção agrícola, comprando antecipadamente na folha (na época do plantio ou nos meses seguintes) a colheita futura do lavrador (por um preço abaixo do preço na época da colheita), traz muitas tensões; em especial quando o lavrador não consegue lhe entregar a produção devida ou em anos de preços altos na safra, quando aumenta para o lavrador o ônus relativo de entregar a

${ }^{20}$ Como no caso das eleições para prefeito em 1966, quando o candidato apoiado pelo Governador do Estado, que inclusive fez campanha por ele pessoalmente até em São Domingos, foi no entanto derrotado pelo fato de não ter sido entregue ao povo um castanhal que havia sido prometido. 
produção pelo preço combinado anteriormente. Quando não se entrega o arroz combinado, dobra o volume devido para ser pago na safra seguinte.

Com a construção da estrada de Apinagés para São Domingos, aumentou o movimento comercial em São Domingos. Os lavradores concentravam a produção em São Domingos, trazida em lombo de burro. Ocorre que não era sempre que havia transporte para a beira ou comprador. Assim, mesmo os que não tinham vendido na folha eram em geral obrigados a vender aos comerciantes locais, que tinham condições de armazenamento em seus estabelecimentos-residências e ganhavam pequena capacidade de jogar com o mercado. Não é raro, mesmo, indivíduos que lhes venderam o arroz depois serem obrigados a comprar de volta para a sua própria subsistência.

O pequeno capital acumulado por esses indivíduos permitia-lhes tirar partido de todas as oportunidades que surgiam. Dois dos mais bem sucedidos, por exemplo, construída a estrada, acabaram por comprar, cada um, um jipe, e pessoalmente, como motoristas aproveitando as viagens que necessitam fazer, exploram o tráfego. Isso se tornará mais importante ainda a partir de julho de 1969, quando a abertura de uma estrada de $54 \mathrm{~km}$ entre São João e Marabá por iniciativa local, realizando uma primeira quebra do isolamento por via terrestre da cidade de Marabá, permitirá a viagem de jipe desde São Domingos até Marabá ${ }^{21}$. Uma das razões das constantes viagens desses indivíduos a Marabá é que para lá transferiram suas famílias, a fim de que os filhos pudessem cursar o ciclo secundário.

Enquanto camponeses remediados, o que vai distinguir essa camada dos demais não é tanto uma produção agrícola maior, mas o fato de irem aos poucos introduzindo algumas cabeças de gado, imitando Marabá em

${ }^{21}$ Numa viagem que nas condições precárias da estrada levará cerca de 3 horas. O único concorrente aos jipes era um antigo lotação do Rio de Janeiro comprado em Belém por um pequeno comerciante de Marabá que fazia o percurso no dobro do tempo, por vezes com interrupções devido a atolamentos, mas que cobrava mais barato e transportava maior quantidade de pessoas. A estrada foi fator importante na interrupção da linha de táxi aéreo que em 1968 funcionara entre Marabá e São Domingos, utilizando pista de pouso aberta em trabalho conjunto dos moradores de São Domingos. Interessante assinalar que essa companhia de táxi aéreo, que opera em extensa área a partir de Marabá, tem sede em Londrina, no Paraná, donde vem a maioria dos seus pilotos. Como se sabe, os táxis aéreos tiveram grande importância no Oeste e Norte do Paraná em sua fase pioneira, enquanto não aumentava a rede de estradas. ponto menor. O primeiro o fará em 1962. Em 1969 o mais bem sucedido terá cerca de 250 cabeças. Os próprios povoados e aglomerados constituirão o seu mercado preferencial; especialmente à medida que a caça escasseia ou a dedicação maior à atividade agrícola exige certa especialização.

Estratificação social. Dessa forma, a produção se liga à estratificação da seguinte maneira:

a) grandes fazendeiros (vindos de Marabá) - ênfase quase absoluta na pecuária (além da castanha);

b) camponeses remediados - pecuária e agricultura, distinguindo-se uma camada superior mais ligada ao comércio em que a pecuária predomina e uma inferior em que se reduz a umas poucas cabeças de gado;

c) pequeno camponês (a maioria) - só agricultura. Aos poucos, muitos agricultores vão plantando pasto junto com o arroz, para não virar simples capoeira. Como não têm em geral recursos para comprar gado e criá-lo, colhido o arroz tendem a vender ou pelo menos alugar o pasto. Nesse último caso, se bem sucedidos poderão através da partilha adquirir uma poucas reses, incluindo-se na camada inferior dos camponeses remediados. Os compradores e alugadores serão, ao lado dos grandes fazendeiros que vão se ampliando especialmente para o lado de São João e Apinagés, a camada superior de camponeses remediados ${ }^{22}$. Até aproximadamente 1967, no entanto, esse processo ainda é relativamente lento.

Afora essa estratificação mais ampla ligada diretamente à produção, dentre a população de São Domingos e da área em torno (o que exclui a), é socialmente reconhecida lima estratificação minuciosa e como que situacional, em que de acordo com as circunstâncias joga-se com elementos estratificadores para estabelecer distinções refinadas onde o observador de fora à primeira vista tenderia a perceber pelo seu modo de vida uma massa quase que homogênea. Assim, é possível distinguir os seguintes elementos estratificadores:

- Possuir uma birosca, realizando negócios em escala mínima, em geral aviado por comerciantes de Marabá ou de São Domingos mesmo.

${ }^{22}$ Curioso assinalar que embora os cearenses sejam minoria em São Domingos, dois dentre os três camponeses-comerciantes mais bem sucedidos são cearenses. 
Muitas vezes é a mulher que explora a birosca, nos intervalos das tarefas domésticas.

- Possuir um ou mais animais (burro, cavalo etc.) com o que se pode transportar a própria mercadoria e empregar-se como tropeiro, especialmente na época da safra da castanha.

- Quebrar coco (babaçu). É considerado sinal de pobreza, sendo realizado exclusivamente por mulheres. De pequeno valor na região, as mulheres catam-no inclusive em terrenos alheios. Todavia, à medida que os rebanhos aumentam, os fazendeiros farão restrições a que se quebre o coco no pasto, pois que a casca deixada pode ferir o gado.

- Posse de objetos em geral: máquina de costura, espingarda, rádio etc.

- Aspecto da habitação: palha ou telha, palha ou pau-a-pique, aberta ou fechada lateralmente.

Esses elementos são fluidos, e um indivíduo ou família pode descer ou subir na escala diversas vezes no decorrer de sua história pessoal, por exemplo devido a um único negócio bem ou mal realizado.

Há pelo menos um elemento, porém, afora as redes, que parece absolutamente essencial que todos possuam, pois está ligado à própria sociabilidade, não distinguindo camadas dentro da comunidade, mas definindo o próprio fato de a ela pertencer: são toscos bancos de madeira com assento de couro que são oferecidos aos transeuntes conhecidos para as conversas que se desenrolam na porta das casas, especialmente à noite.

\section{As Novas Transformações Supra Locais e os seus Reflexos}

Entre 1953 e 1963, a área de cultura e o volume da produção de arroz do Maranhão duplicaram (ANDRADE, p. 87). É importante assinalar que o arroz é o produto através do qual no Centro-Norte realiza-se em geral hoje a passagem entre agricultura de subsistência e agricultura de mercado. À medida que aumentam as possibilidades de comercialização, aumenta a proporção de arroz que se cultiva em relação aos demais produtos tradicionais.

O aumento da produção constitui-se num fenômeno do qual a abertura da Belém-Brasília é parte importante, mas não exclusiva, já que a sua presença só se faz sentir praticamente a partir de 1959. Mesmo porque, de início o processo desenvolveu-se em sua maior parte mais para Leste.

Ocorre que há uma certa coincidência entre o aumento na pressão da frente agrícola para Oeste e a chegada da estrada, apesar dessa pressão já vir se fazendo desde o início da década. E sem dúvida a estrada, se não é fundamental para o início do movimento, o é no sentido da transformação do caráter da destinação da agricultura que se pratica e, consequentemente, na sua especialização e intensidade.

A estrada de fato não passará pela cidade de Imperatriz, à beira do Tocantins, mas a três quilômetros de distância. Esses três quilômetros, no entanto, são rapidamente preenchidos, e a pequena cidade beira-rio e de aspecto colonial, que pouco havia sido afetada em seu aspecto urbano pelo movimento havido na década de 50, que foi quase exclusivamente rural e ainda muito voltado para a subsistência, é em breve obscurecida pela nova cidade que surge com características de boom só comparáveis em seu ritmo ao novo núcleo de Araguaína, no Norte de Goiás. No final da década de 60 estará se aproximando dos 40.000 habitantes, constituindo-se na maior cidade do Estado do Maranhão depois de São Luís, à frente, inclusive, de Caxias. Ultrapassa longe, pelo menos por ora, Marabá, a quem servia de porto de ligação, redefinindo suas relações com essa cidade. Ao mesmo tempo, as relações comerciais, que na década de 50 haviam se intensificado com Fortaleza e Recife, em detrimento de São Luís, passam agora a voltarse para o Sul. No interior do município e nos outros em torno proliferam os aglomerados rurais. A cidade realizará, no final da década, por sua posição privilegiada, a comercialização não só da sua própria produção de arroz, mas também, no Maranhão: de Sítio Novo, Amarante do Maranhão, Montes Altos, João Lisboa e Grajaú; em Goiás: de Itaguatins, Sítio Novo de Goiás, Axixá, São Sebastião do Tocantins, Araguatins, Xambioá; e no Pará: de São João do Araguaia, Marabá, Itupiranga, Paragominas. O imposto devido por esses produtos tenderá a ser retardado para ser pago só em Imperatriz, constituindo importante fonte de recursos para esse município.

Instalam-se em Imperatriz beneficiadores de arroz vindos do Sul, criando-se um importante eixo comercial Imperatriz-Anápolis.

Em breve se atrairá uma outra corrente migratória, esta sim posterior à estrada, de pecuaristas goianos, baianos etc., Com eles aparecerão, numa 
nova forma, alguns dos problemas de terras que a frente já conhecera em outras áreas.

O arroz tenderá a ser enviado para o Sul, em geral como carga de retorno dos caminhões que demandam especialmente Belém; e o gado irá, afora o consumo local, para a área de Belém.

Porém o tempo em que se fazem sentir os efeitos da estrada em cada área varia na razão direta da distância dela e dos caminhoneiros que a atravessam $^{23}$, abstraída a interveniência de outras variáveis de que trataremos adiante. Em São João os efeitos serão muito mais espalhados no tempo $^{24}$. Entre Imperatriz e Apinagés medeiam mais de 200 quilômetros de Tocantins, e entre Apinagés e São Domingos mais 17 quilômetros de estrada; sem falar das distâncias entre os moradores da mata e São Domingos.

No entanto, com o tempo efetivamente outros fatores se farão sentir. Antes de mais nada, a própria pressão da frente na altura de Imperatriz, transbordando gente para o lado do Pará. O município de São João do Araguaia, que ainda como distrito de Marabá tinha em 1960 cerca de 7.500 habitantes, no final da década terá mais do que dobrado a sua população.

E há, ainda, outras influências. A partir de 1960 o Banco do Brasil inaugura uma política de crédito ao pequeno produtor rural mais liberal. Dele se exigia apenas a escritura de propriedade, uma carta de anuência do proprietário ou uma simples garantia de posse efetiva, conforme o caso. Ocorre que em 1964 abre-se uma agência do Banco do Brasil em Marabá e em 18 de setembro do mesmo ano o Governo do Estado baixa o Dec. $\mathrm{n}^{\circ}$ 4.457, que dispõe sobre a ocupação provisória de terras. Por esse decreto,

${ }^{23}$ Sobre o papel crescente dos caminhoneiros no processo de comercialização de produtos primários e na sua relativa modernização, ver AVERBUG.

${ }^{24}$ Mas na cidade de Marabá, propriamente, já haverá alguns resultados mais imediatos, como, por exemplo, no comércio, com um barateamento geral das mercadorias e a diminuição da dependência em relação ao comércio de Belém, aumentando a influência comercial do Centro-Sul do país, especialmente através de São Paulo e Anápolis. Todavia, isso só fez aumentar o controle do comércio local, já que diminuíra a influência de Belém e a estrada não tendo passado por Marabá, os caminhoneiros não podiam ir diretamente até lá. Isso só se alterará com a Transamazônica. Outro efeito mais imediato será a decadência e mesmo o fechamento de algumas pequenas indústrias locais, como a de sapatos, muito próximas de uma tradição artesanal e impossibilitadas de concorrer com as novas fontes de suprimento. mediante uma prova de ocupação, sem requerimento e na prática sem verificação in loco, através das prefeituras municipais expediam-se títulos provisórios de ocupação das terras devolutas numa extensão de até 100 ha que eram aceitos pelo Banco do Brasil para fins de concessão de empréstimos. Tratava-se de título extremamente simples e expedido com grande facilidade, junto à coletoria estadual no município, inaugurando uma política de homestead.

Ao mesmo tempo, diante do novo interesse em conseguir o empréstimo, que certamente constituiu, aliás, uma das razões principais para a expedição do Decreto, pela primeira vez surge um motivo imediato e concreto para legalizar a situação dos que ocupavam as chamadas terras do município, como os castanhais comprados em São João do Araguaia, e que foram as primeiras terras ocupadas pelos agricultores de São Domingos. Com isso, passa-se a distribuir através das prefeituras títulos de aforamento das terras municipais.

Tudo isso constituiu uma grande novidade. Particularmente para os participantes mais antigos da expansão da frente no Maranhão, para os quais a questão da legalização da posse nunca tinha se colocado.

Para efeitos imediatos - particularmente no que diz respeito à concessão de empréstimos bancários - os dois gêneros de título pouco diferiam entre si. Não era raro o mesmo indivíduo ocupar terras do município e terras devolutas do Estado. Por vezes utilizava-se o expediente de colocar os diversos títulos em nome de diferentes membros da família. Com isso podia-se acumular vários lotes, o que era feito em especial pelos camponeses remediados.

Segue-se uma fase de grande entusiasmo na ocupação de terras e de plantio, particularmente entre 1964 e 1967. O fato do vizinho Estado do Maranhão não estar distribuindo títulos de terra acelera ainda mais a passagem para o Pará. Em 1966 São Domingos terá mais de 200 casas, e em 1969, ano em que é proibida a existência de currais dentro do povoado, cerca de 350, num total aproximado de 1.800 pessoas, distribuídas em duas vias principais e diversas secundárias, e surgindo casas em que já se utiliza telhas e parcialmente o tijolo. No setor de serviços incluir-se-á três barbeiros, três oficinas de alfaiate, um radiotécnico, três carpintarias, dois ferreiros, dois sapateiros (inclusive fabricando sapatos), cinco pensões, diversos armazéns e farmácias, além de inúmeras biroscas. 
Na mata em torno, especialmente na direção das terras devolutas e desocupadas para Oeste, Sudoeste e Sul, o aumento ainda é no conjunto proporcionalmente maior, constituindo-se diversos aglomerados secundários e outros, mais longe, bastante desenvolvidos (como Palestina). O Banco do Brasil chega a ter cerca de 2.000 pequenos financiados. Sua distribuição aproximada dá uma ideia comparativa da importância da produção agrícola nos vários municípios, com São João do Araguaia comparecendo com praticamente $50 \%$ do total:

QUADRO XII

\begin{tabular}{lc}
\hline Municipio & No aproximado de financiados \\
\hline São João do Araguaia & 960 \\
Marabá & 200 \\
Tucuruí & 280 \\
Jacundá & 160 \\
ltupiranga & 400 \\
\hline
\end{tabular}

O total aplicado chegou a Cr\$ 2.000.000,00, com empréstimos individuais em geral correspondentes a 5 vezes o salário-mínimo. Apesar das demoras, e dos gastos em viagem e estada em Marabá, que custava a concessão de um empréstimo, nesta fase a ação do Banco contribui decisivamente para a euforia desenvolvimentista. $\mathrm{O}$ que não exclui que isso só tenha sido possível pela existência de condições locais objetivas propícias, apesar da importância inclusive do elemento pessoal (a figura do gerente especialmente), já que em outras áreas o papel do Banco era bem diferente, e mesmo nesse caso 'mudará com as circunstâncias.

Em 1965, estimulada pelo Banco do Brasil, abre-se uma Cooperativa Agrícola em Marabá (COPEMA) que passa a recolher o arroz dos sócios, e à qual se filiam de modo praticamente compulsório os que pretendiam se beneficiar de empréstimos agrícolas do Banco do Brasil. A ação conjunta do Banco e da Cooperativa reduz a importância dos comerciantefinanciadores enquanto tais, e acelera a sua passagem para a produção, beneficiando-se, também, dos empréstimos.

Assim, a partir de 1964, alguns anos depois de aberta a BelémBrasília, a zona passa a exportar quantidades crescentes de arroz, cujo montante é difícil avaliar dada a prática - até o advento da Transamazônica
- de retardar o pagamento dos impostos (ICM) até Imperatriz, a grande beneficiada. Sabe-se, porém, que São João e Araguatins (GO) são dos municípios que mais mandavam arroz para Imperatriz ${ }^{25}$

Junta-se, efetivamente, ao boi e à castanha dos grandes produtores a produção de arroz dos pequenos lavradores, inaugurando, de fato, uma nova fase na história da região.

Em 1967, uma resolução da Câmara Municipal de São João do Araguaia muda oficialmente o nome de São Domingos das Latas para São Domingos do Araguaia.

\section{O Mercado Nacional de Arroz}

Não é preciso acentuar a importância do arroz na alimentação no Brasil. Basta dizer que, apesar das oscilações de curto prazo, que são muitas, sua produção tem tendido a aumentar acompanhando o crescimento de nosso mercado interno, de tal maneira que em meados da década de 60 já se apresentava em primeiro lugar, quanto ao valor, entre os produtos agrícolas; seguido, no período 1966-68, do milho, com o café vindo então somente em terceiro lugar. ${ }^{26}$ Embora a oferta tenha se mostrado bastante irregular de ano para ano, apresentou no período 1950-67 um incremento médio de $5 \%$ ao ano (SUNAB).

Os principais Estados produtores têm sido Rio Grande do Sul, Goiás, Minas Gerais, São Paulo, Maranhão, Mato Grosso, Paraná e Santa Catarina. O Maranhão tem mantido com regularidade a quinta colocação entre os Estados produtores. Essa posição constante é coerente com a ação itinerante da frente agrícola que já vem se fazendo sentir há vários anos. Todavia, em números absolutos, o salto mais espetacular de sua produção dá-se em 1961, quando passa de 277.741 toneladas no ano anterior, para 491.500 toneladas (SUNAB); o que deve refletir os efeitos sobre a produção e a comercialização da Belém-Brasília a Oeste. A produção do Sul do Para,

${ }^{25}$ Informação da Agenda de Estatística em Imperatriz. A Agência de Estatística da Fundação IBGE em Marabá calculava em cerca de 30 mil sacas (de $60 \mathrm{~kg}$ ) a exportação de arroz de São João do Araguaia em 1968, o que equivaleria a 1.800 toneladas (no mesmo período, a produção de Marabá teria sido de 11 mil sacas). Pelas razões apontadas, é possível que a produção tenha sido maior.

${ }^{26}$ Em 1969 desceu à terceira colocação, mas em 1970 já voltava à primeira (FIBGE, 1971c, pp. 145/146) 
pelas razões já apontadas, até 1972 deve ter sido computada como maranhense.

Quanto aos grandes centros consumidores, segundo pesquisa feita pela CIBRAZEM em 1965 no Centro-Sul, Porto Alegre seria abastecido com arroz do próprio Estado; Curitiba com arroz paranaense, gaúcho e catarinense; São Paulo preponderantemente com o do próprio Estado, mas também de quase todas as zonas produtoras, especialmente em anos de safras pau listas menores; o arroz para Belo Horizonte e Brasília viria do Triângulo Mineiro e de Goiás. Quanto ao Grande Rio, a maior parte do arroz seria goiano e gaúcho, porém cerca de $10 \%$ seria maranhense. Assim, apesar do arroz maranhense ser comercializado através de Minas Gerais e São Paulo, aparentemente o maior centro consumidor era o Rio de Janeiro (CIBRAZEM, p. 169).

$\mathrm{O}$ arroz das diversas procedências chega aos centros consumidores com preços diversos, dependendo muito da preferência dos consumidores. O arroz do Maranhão, de grãos curtos, é considerado de qualidade inferior $^{27}$. Uma observação dos preços em diversas casas comerciais da Guanabara no final de 1969 mostrou a seguinte distribuição aproximada:

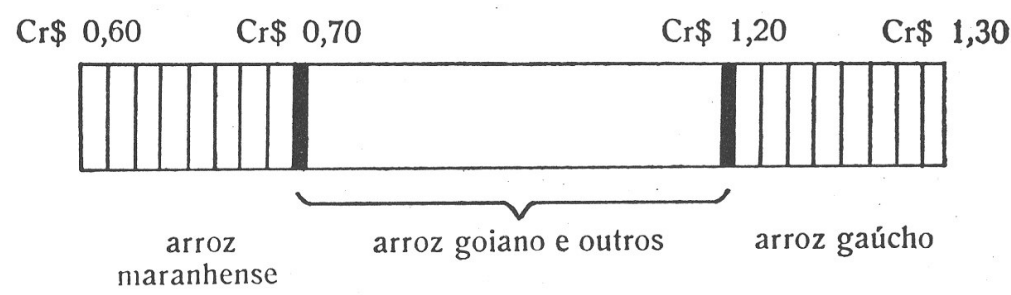

O peso maior do mercado parece repousar sobre o arroz goiano e outros, com certa oscilação sazonal e de ano para ano nos limites que alcança. $\mathrm{O}$ arroz maranhense e o gaúcho ocupam aparentemente posições simétricas opostas.

Segundo estudo feito pela SUNAB (1969) para todo o Brasil, o maior volume do abastecimento fica por conta de Goiás, Minas Gerais, Mato Grosso e São Paulo, o que explica o grande interesse do Governo na

${ }^{27} \mathrm{O}$ arroz é predominantemente do tipo catete, que exige menos cuidados do que outras variedades. formulação de planos de escoamento do arroz goiano. O Rio Grande do Sul, afora o abastecimento do próprio Estado, segundo o próprio estudo da SUNAB, teria "uma condição supletiva de mercado, sobretudo quando a produção da Região Centro-Oeste é baixa" (SUNAB, p. 44). Quando a oferta é satisfatória, parte do arroz gaúcho, que é obtido em culturas irrigadas, com técnica bastante aperfeiçoada, é desviado para o mercado internacional $^{28}$; o que, aliás, cria por vezes sérios problemas de estocagem. Para isso recebe-se grande apoio do Governo, através de créditos concedidos ao Instituto Riograndense do Arroz e às Cooperativas Arrozeiras, o que deverá ocorrer cada vez mais em face da política de estímulo à exportação agrícola.

Já o arroz maranhense, segundo a SUNAB, "é consumido pela classe de baixo poder aquisitivo, pois o seu preço e qualidade são inferiores aos demais produzidos em outras regiões" (p. 44).

Assim, poder-se-ia concluir que o arroz do Maranhão possui uma clientela nas camadas inferiores da cidade e, provavelmente, uma faixa imediatamente a seguir em que exerceria, também, uma função supletiva. Tal como o produtor gaúcho buscaria o mercado internacional nos momentos de alta oferta, o produtor maranhense retrair-se-ia para o setor de subsistência, já que, conforme os estudos mais recentes parecem indicar, o coeficiente de elasticidade-preço da procura dos produtos agrícolas no Brasil, particularmente de produtos tais como farinha de mandioca, arroz, milho, feijão etc. - exatamente os produtos tradicionais da lavoura de subsistência - é baixo (PAIVA, pp. 218/233). Com isso, parte da produção não chega a aparecer nas estatísticas. Só, aliás, o caráter camponês da agricultura maranhense-paraense, próximo sempre às fímbrias da subsistência, parece permitir custos tão baixos, onde não é computado o salário que o camponês deixa de pagar a si mesmo quando necessário, a ponto de, após percorrer milhares de quilômetros, o produto ainda chegar relativamente barato aos pobres da cidade. Nisso têm influência também as recentes melhorias nos meios de transporte e comunicação. Poderíamos dizer, então, que teríamos os pobres do campo produzindo para os pobres da cidade; cobrindo, assim, uma faixa que, se é minoritária, no entanto não

${ }^{28}$ Em condições normais, aparentemente a distribuição é a seguinte: 600 mil toneladas para consumo no próprio Estado, 500 mil toneladas para o mercado nacional, e 200 mil toneladas para exportação. 
deixa de ser socialmente crucial em um sentido duas vezes próximo à marginalidade.

\section{São Domingos do Araguaia}

Os financiamentos do Branco do Brasil, que coincidem aproximadamente com a entrada mais decisiva na agricultura de mercado para os lavradores da área, tiveram várias consequências cruciais. Uma delas foi o aumento relativo do arroz no volume geral de produtos plantados. Aparentemente, se antes de 1964 o arroz para a maioria constituía cerca de 40 a $50 \%$ do que era plantado, a partir de então eleva-se a cerca de 70 a $80 \%$, sendo tanto mais quanto maior a área total plantada. E a área total de plantio expandiu-se em aproximadamente 100 a $200 \%$ para cada um dos financiados. Com isso, surgiu a necessidade mais significativa de mão-de-obra extrafamiliar, que até então, em quase todos os casos, só era utilizada ocasionalmente, não sendo rara a troca de serviços entre vizinhos. Eis o calendário agrícola, com as tarefas que se apresentam:

- Janeiro - limpeza de roça e plantio de arroz, feijão de lastro, milho, fava e mandioca (subsistência).

- Fevereiro - limpeza de roça e plantio de mandioca e feijão de lastro (subsistência).

- Março - limpeza de roça e plantio de mandioca e feijão de lastro (subsistência).

- Abril - colheita do arroz.

- Maio - colheita do arroz.

- Junho - colheita de arroz, milho, feijão e fava. Começo da quebra do milho. Brocar roça.

- Julho - quebra do milho. Colheita de feijão e fava. Broca e derrubada (para roça).

- Agosto - derrubada. Colheita de fava e feijão.

- Setembro - limpeza de roça. Derrubada e queimada.

- Outubro - limpeza de roça. Queimada e coivara. Plantio de feijão e milho.

- Novembro - limpeza de roça.

- Dezembro - plantio de arroz, milho, mandioca, feijão, fava.
Com o tempo, muitos lavradores passarão a iniciar o plantio em outubro e novembro (em vez de dezembro e janeiro) para se conseguir colher mais cedo e poder vender logo o produto; como também para não coincidir a colheita com o preparo da roça para o plantio seguinte, que tem de ser feito de maneira que a queimada se realize antes das chuvas. Essa mudança sem dúvida está relacionada à passagem do arroz à categoria de produto comercial por excelência.

É de se notar como nessa área, ao contrário de outras mais próximas ao cerrado, a necessidade de limpeza de roça torna-se quase uma constante durante o ano. Todavia, é na época da colheita que as necessidades de mãode-obra de fato aumentam, atingindo por vezes o dobro do resto do ano. Isso se deve inclusive à técnica até agora predominante: o arroz, de sequeiro, é colhido a mão no cacho, como se faz no Maranhão, e não cortando no pé, tal como no Sul de Goiás. Para se conseguir mão-de-obra suficiente para a colheita, o sistema usual consiste em fazer adjunto ou trocar dia com os vizinhos (uma espécie de mutirão), além de empregar as mulheres e crianças da família.

Com a intensificação geral da atividade agrícola, tornou-se difícil encontrar vizinhos disponíveis, e a mão-de-obra assalariada, constituída quase que exclusivamente dos recém chegados do Maranhão que se empregavam por alguns meses, mostrou-se também insuficiente. Em muitos casos, então, os lavradores só conseguiram colher parte do que plantaram. Alguns dos mais industriosos passaram a utilizar o "sistema goiano" (por efeito-demonstração provocado pelo aparecimento na área de uma família de goianos de Ceres, por eles considerados mineiros); a maioria, porém, ofereceu considerável resistência a essas mudanças, alegando as exigências de maior espaço e cuidado no armazenamento imediato dos pés colhidos que este sistema apresenta. Por ocasião da colheita, dada a escassez de mãode-obra, esta se torna extremamente valorizada, tendo-se chegado a pagar no final da safra, em casos excepcionais, mas não raros, a terça e mesmo a meia só pela colheita, o que por si constituiu um motivo de atração para a área. Há quem aceite ficar trabalhando com pouca remuneração em outras épocas do ano só para "segurar o lugar" na colheita ${ }^{29}$. ${ }^{29}$ Em geral, o pagamento é por diária ou por empreitada (empeleita). Em 1969, a diária foi
de cerca de Cr\$3,00. Eis alguns preços de empreitada:

- Brocar e derrubar 1 quadra (leva cerca de um mês) - Cr\$250,00. 
Os financiamentos, afora o que se gastava antecipadamente no processo de consegui-los, foram consumidos quase integralmente para contratar pessoal, sem investimentos na terra. Um pequeno saldo ficava para a compra de implementos agrícolas. O corte entre a maioria dos lavradores e os camponeses remediados passou a situar-se aproximadamente em 5 braços utilizados na lavoura, entre os quais podiam se contar ou não cerca de um ou dois membros da família e, no caso do pequeno lavrador, ele próprio. Além disso, entre os remediados as variações sazonais de emprego de mão-de-obra mantêm-se menores, especialmente devido à prática da pecuária. Houve, porém, muitos casos em que o pequeno lavrador, com o empréstimo, afastou-se em parte da produção direta. Como se diz na área: "Com o empréstimo, todo o mundo quis ser patrão"; o que obviamente não era o que se pretendia. O número máximo de indivíduos contratados por um só lavrador foi doze; e, por outro lado, no outro extremo, especialmente em certos casos em que não se conseguiu o empréstimo ou, por desconfiança, não se o procurou, havia lavradores que continuaram a trabalhar sozinhos, ou com algum parente, em geral filhos.

Ao mesmo tempo, diversos camponeses remediados foram se utilizando de empréstimos feitos pelo BID através do Banco da Amazônia para comprar gado. Alguns dos mais bem sucedidos no eixo São Domingos-Apinagés chegarão a ter em torno de 200 cabeças. Outros não passarão de dez.

Os financiamentos tiveram consequências contraditórias. Se por um lado, a curto prazo, ampliaram a área plantada, por outro trouxeram certos elementos de insegurança que aceleraram a concentração e a passagem para a pecuária que já se processava muito lentamente. Entre eles conta-se o próprio fato mencionado da expansão das atividades além do que era viável em face dos recursos humanos disponíveis e um afastamento do padrão camponês de trabalho para si próprio. A isso veio se somar o próprio

- Coivara da roça - com muito garrancho: Cr\$60,00 a Cr\$, 100,00 a quadra. Em alguns casos pode chegar a $\mathrm{Cr} \$ 200,00$, levando 30 a 40 dias; - com pouco garrancho: $\mathrm{Cr} \$ 50,00 \mathrm{a}$ $\mathrm{Cr} \$ 60,00$ a quadra (cerca de 10 dias).

- Plantio da roça - Cr\$ 5,00 a Cr\$ 6,00 a linha. Uma quadra (16 linhas) pode ser feita em cerca de 12 dias.

- Colheita - em média Cr\$3,00 o saco (de $60 \mathrm{~kg})$.

- Fazer cerca - Cr\$1,50 por braça (2 metros). Um homem faz 150 braças por mês.

- Roçar pastagem - Cr\$ 150,00 uma quadra (em cerca de um mês). reembolso do Banco, com juros, de natureza impessoal e impostergável, que sob certos aspectos era mais duro para o lavrador do que a própria relação tradicional com o pequeno comerciante-financiador. A atividade do Banco reduzia-se praticamente à concessão de empréstimo e a sua cobrança posterior, sem auxílio técnico ou acompanhamento das atividades, dada inclusive as suas poucas disponibilidades de pessoal em face da grande amplitude dos empréstimos concedidos e o acesso difícil à maior parte das áreas.

Acrescente-se a isso que houve um grande estouro da Cooperativa, que fez com que os lavradores, depois de entregue a produção à Cooperativa, continuassem a ficar devendo ao Banco, por vezes até milhares de cruzeiros. O estouro ligou-se, sem dúvida, como clímax, ao próprio movimento de grande e rápida expansão das atividades do Banco e daquelas que ele estimulou. A história do cooperativismo no Brasil está cheia de casos semelhantes, e só isso mereceria um estudo à parte. É difícil, porém, saber até que ponto o problema não foi agravado pela ação de interesses contrariados pela existência da cooperativa, que aumentaram as dimensões da questão inicial de peculato e com isso ajudaram a impedir uma solução menos desastrosa. O fato é que tratou-se de um grande escândalo, em que tanto o Banco quanto os lavradores tiveram grandes prejuízos. Em consequência, o Banco, para resguardar-se, passou bruscamente de uma atitude desenvolvimentista para uma atitude empresarial, o que representou novo choque para os lavradores.

Ideologia. É difícil aquilatar as consequências subjetivas do fato. Pode-se imaginar o esforço que não foi para os lavradores ajustar-se ao novo esquema de trabalho com o Banco, quando os mais desconfiados falavam em "negócio da besta-fera", que iria arruiná-los etc., o que acabou por confirmar-se, demonstrando como é problemático aqui/atar-se a priori o que seja a ação racional numa situação em que nem sempre há coerência entre a racionalidade do agente e a do sistema.

Sem dúvida nenhuma, dá-se uma tendência à regressão às atitudes mais tradicionais, que acompanha a reaproximação da subsistência ou a fuga para outros lugares.

Embora a fuga para outros lugares não seja tradicional quando vista numa perspectiva histórica mais ampla, onde se salienta a imobilização da mão-de-obra nas grandes propriedades, vai-se transformando, a partir da 
segunda metade do século XIX, para amplas camadas, num comportamento característico, aderindo a uma atitude social que sempre esteve presente para os marginais do sistema. Como salienta MAYBURY-LEWIS, por vezes é difícil identificar uma causa aparente imediata para esse nomadismo, que parece prender-se a uma "desconfiança no sistemas de raízes profundas. É preciso dizer que uma vez inserido na frente agrícola maranhense, essa "desconfianças e fuga" ligam-se em geral à possibilidade de contestação de sua posse da terra, que acaba seguidamente por transformar-se em penosa realidade, que se ajusta perfeitamente ao fato objetivo da disponibilidade de terras adiante e ao modo de exploração agrícola. A "fuga" denuncia, sem dúvida alguma, até certo ponto, falta de apego a um pedaço particular de terra, em torno do qual não pôde chegar a cristalizar-se uma ideologia camponesa típica por razões objetivas; mas também denuncia o desejo de alguma terra, embora não somente pela terra em si, mas como uma forma de realização do ideal de ser patrão de si mesmo $^{30}$. A essa ambiguidade na maneira de encarar a terra, fim e instrumento, talvez se prenda o próprio caráter não-unívoco da comunidade, que apresenta simultânea ou sucessivamente aspectos fechados e abertos ${ }^{31}$. A "desconfiança", para os homens da frente, parece alcançar todos os níveis; o que chegou a levar o pesquisador, na tensa situação criada pelo caso da cooperativa, a ser considerado por alguns um possível enviado da "besta-fera que haveria de vir", a qual era identificada com o Presidente da República, e que lhes tiraria as terras e promoveria "a volta do cativeiro". Isso parece contrastar com a imagem paternalista que se faz do Governo em certas regiões, onde se está submetido a uma situação que sob certo ângulo ainda pode ser vista como uma transformação da situação mais tradicional, relativamente pouco parecendo depender, no limite, da ação pessoal do indivíduo, mas com a imagem paternalista deslocada do patrão concreto para um último e grande patrão mítico, que é o Governo.

A categoria de cativeiro é extremamente importante nas formulações ideológicas dos participantes da frente. A referência mais estrita prende-se à escravatura, tal como existiu até a sua abolição. O que os impressiona fundamentalmente no cativeiro, tal como ouvem contar, é o fato de trabalhar-se sem receber nada em troca, a não ser alguma roupa e comida.

\footnotetext{
${ }^{30}$ Ver, a propósito, QUEIROZ, 1965.
}

${ }^{31}$ Ver WOLF, 1955
Por extensão, qualquer situação considerada de muita exploração e perda de autonomia é identificada com o cativeiro. Simplesmente trabalhar regularmente como empregado já apresentaria certas características de cativeiro $^{32}$. Por isso mesmo, tendo de realizar um serviço para alguém, o que se prefere sempre é a empreitada (empeleita).

Porém, em sua forma mais acabada, o cativeiro é a pura e simples escravidão, que contrastaria com a situação hoje vivida pelos lavradores, em que cada um decide como orientar a sua vida, não está sujeito a horários, não precisa trabalhar quando se sente doente, pode se deslocar para outra região quando lhe der vontade; enfim, exercer a sua liberdade, o que talvez ajude a compreender, no plano ideológico, o chamado nomadismo do brasileiro do interior. Existe, entre os participantes da frente, numa espécie de anti-revivalismo, o medo constante de que o presente, relativamente bom, ou pelo menos livre, será substituído no futuro por uma volta ao passado de cativeiro, que viria através da ação dos ricos, do Governo $^{33}$ e talvez de estrangeiros. A diferença entre o antigo e o novo cativeiro é que este atingiria não só os pretos, mas os pobres em geral, já que os pretos estão misturados no meio do povo. Talvez, aliás, se ligue a isso certas manifestações claras de racismo, que poderiam representar um esforço de separar-se dos pretos, contra quem se dirige, preferencialmente, o cativeiro ${ }^{34}$.

Segundo muitos, há sinais de que esse tempo do cativeiro se aproxima, o que pode ser comprovado, por exemplo, pela ação dos grileiros nas suas terras de origem, pelo fato de os fazendeiros estarem fazendo restrições a que as mulheres quebrem babaçu em suas terras e por qualquer tentativa governamental de ingerência em sua liberdade. $\mathrm{O}$ episódio da cooperativa só fez confirmar essa opinião ${ }^{35}$.

${ }^{32}$ É dessa forma que um indivíduo residente em São Domingos justifica não ter aguentado trabalhar numa grande fábrica de automóveis em São Paulo, apesar de toda a assistência que, reconhece, existia.

Nesse sentido, o comunismo seria urna variedade de cativeiro. Eles manifestam grande receio de que o Governo se torne ou esteja se tornando comunista.

${ }^{4}$ Todavia, parecem de acordo em que, em suas terras de origem, a separação entre pretos e brancos (para nós, de fato em geral pardos) era maior, pois, por exemplo, em festa de branco preto não entrava, e vice-versa.

${ }^{5}$ Padre Cícero, segundo eles, disse que o cativeiro voltaria, e nesse tempo não haveria mais inverno e verão, o povo ficaria como formiga andando dum lado para o outro sem se 
Entre alguns camponeses remediados manifesta-se certa dúvida quanto à volta do cativeiro. Segundo um deles, o que chamam de cativeiro é o domínio das leis, "e isso é um cativeiro bom". Todavia, a questão é aceita pelo menos como motivo de discussão séria.

\section{$* *$}

O caráter fundamentalmente supletivo da produção de arroz da região nos grandes mercados provoca baixas periódicas de preços; particularmente em anos de grandes safras nos principais centros produtores. Essas baixas de preços tornam-se ruinosas quando estão muito dependentes do mercado, inclusive devido a compromissos bancários que tornam mais problemático o retorno à subsistência. É o que ocorreu em 1969. As coisas chegaram a tal ponto, que o milho passou a oferecer preço melhor (Cr\$18,00 em Marabá; Cr\$ 32,00 em Belém), o que pouco adiantou, pois a produção para o mercado havia sido concentrada no arroz. O preço do arroz em Imperatriz chegou a descer até $\operatorname{Cr} \$ 8,00$ o saco de $60 \mathrm{~kg}$, subindo depois na entressafra até $\mathrm{Cr} \$ 14,50$ e estabilizando um pouco em torno de $\mathrm{Cr} \$ 12,00$.

Com o fracasso da cooperativa, o esquema da comercialização local passou a ser:

a) venda do lavrador para o comerciante local em São Domingos;

b) venda do comerciante local a representantes de firmas beneficiadoras e compradoras de Imperatriz que passaram a vir pelo rio até Apinagés e São Domingos.

Voltou a aumentar a força dos comerciantes enquanto tais. Os custos nessa comercialização, por saco, foram em média, no final de 1969:

Pagamento a tropeiro para transporte da mata até São Domingos:

$\mathrm{Cr} \$ 1,00$

(aproximado)

$\begin{array}{ll}\text { Pagamento a caminhão para transporte São Domingos-Apinagés: } & \mathrm{Cr} \$ 1,00 \\ \text { Pagamento para transporte de barco até Imperatriz: } & \mathrm{Cr} \$ 1,50\end{array}$

Pagamento ICM:

$\mathrm{Cr} \$ 1,50$

(aproximado)

Supondo um acréscimo de apenas Cr\$1,00 por conta do lucro do comerciante local, teríamos que o preço pago ao produtor, quando o preço em Imperatriz era de $\mathrm{Cr} \$ 13,00$, seria de $\mathrm{Cr} \$ 7,00$, o que em geral não

aquietar, nação voltar-se-ia contra nação, pai contra filho e filho contra pai. Tudo isso já estaria começando a acontecer. ocorreu, pois os lavradores não puderam esperar essa pequena alta, de que se beneficiaram os comerciantes locais que armazenaram o produto. Podemos imaginar, sem pessimismo, uma participação do produtor de $\mathrm{Cr} \$$ 6,00 por saco de arroz. Supondo agora um preço final nos mercados do Centro-Sul de Cr\$ 0,60 o kg (ver p. 124), teríamos Cr\$36,00 equivalentes ao saco de $60 \mathrm{~kg}$. Assim, o percentual do preço final que ficaria nas mãos do produtor seria de apenas um pouco mais de $15 \%$, muitas vezes, certamente, baixando mais ainda. Para se comparar, citamos a participação dos produtores de arroz de outras regiões do país no preço final do produto em 1966 e 1967:

Rio Grande do Sul: $41 \%$ e $43 \%$

São Paulo: $60 \%$ e $54 \%$

Minas Gerais: $53 \%$ e $47 \%$

Goiás: $56 \%$ e $48 \%$

(Fonte: SUNAB. p. 32)

Deve-se lembrar mais uma vez que do pequeno lucro do lavrador deveria ser retirado o pagamento das dívidas com o Banco do Brasil. Obviamente, o caso presente só pode ser entendido encarando-se como um tipo de produção de natureza diferente das demais que foram citadas, e que se deve exatamente ao seu caráter camponês, em que a mão-de-obra relativamente constante da unidade familiar permite uma alta dose de sobre trabalho.

A área de São Domingos, no entanto, não representou na região um caso extremo. Eis um exemplo de custos de comercialização em 1969 para Itamirim, área que beira o Araguaia mais ao sul e onde se formaram em poucos anos diversos aglomerados, sendo que um (Palestina) quase rivaliza em tamanho com São Domingos:

Transporte da roça ao aglomerado:

Cr\$ 1,00

Transporte do aglomerado até a beira-rio:

$\mathrm{Cr} \$ 1,20$

Custo de embarque:

Transporte fluvial até Apinagés:

Cr\$ 0,20

$\mathrm{Cr} \$ 1,20$

Custo do saco vazio:

$\frac{\mathrm{Cr} \$ 2,50}{\mathrm{Cr} \$ 6,10}$

TOTAL:

Conseguindo vender em Apinagés por exemplo a Cr\$ 9,00, sobrariam $\mathrm{Cr} \$ 2,90$. 
Se a esses custos de comercialização, porém, acrescentarmos os próprios custos de produção na mesma área, poderemos aquilatar os custos totais envolvidos para o agricultor.

Supondo que uma quadra de terras permita uma produção equivalente a aproximadamente $100 \operatorname{sacos}^{36}$, e levando em conta os preços vigentes (ver nota 29), teremos os seguintes custos de produção:

\section{Cr\$250,00 para brocar e derrubar}

Cr\$ 80,00 para plantar

Cr\$ 80,00 para limpar

Cr\$ 80,00 para a segunda limpar

Cr\$ 250,00 para colher

Somando, teremos Cr\$ 740,00; donde, $\operatorname{Cr} \$$ 7,40 o saco.

Se acrescentarmos as despesas de comercialização de Cr\$ 6,10 já mencionadas, teremos um total de despesas de $\operatorname{Cr} \$ 13,50$ por saco.

Obviamente, nessas condições, supondo um preço de venda em torno de $\mathrm{Cr} \$$ 9,00, mesmo que o lavrador realize quase todas as tarefas de produção sozinho, torna-se inviável a produção voltada preferencialmente para o mercado, pelo menos em anos de alta oferta. A curto prazo, só lhe resta vender a produção para um comerciante local, o que lhe dará apenas um pouco mais do que em Apinagés depois de deduzidas as despesas de transporte até lá.

Muitos moradores de Itamirim em 1969 estavam internando-se mais no mato. Segundo um deles: "Na rua não está dando para viver. No mato pode-se viver até nu. E lá tem caça, pode-se plantar mais mandioca e criar galinha." A vida no aglomerado é identificada com as possibilidades de comercialização, e em tempos difíceis é preferível estar no centro. Outros procuram localização comercialmente mais vantajosa, especialmente próximo à PA-70, provocando uma redistribuição intrarregional da população.

${ }^{36} \mathrm{O}$ que corresponde aproximadamente a $1.250 \mathrm{~kg}$ por hectare, ficando um pouco abaixo da média brasileira em 1961-63, que foi calculada em $1.634 \mathrm{~kg}$ (PAIVA, p. 202). O Banco do Brasil trabalha com a suposição de um rendimento de 160 sacos por quadra, $60 \%$ a mais, o que é considerado irrealista, devido à existência de muita madeira, mesmo depois da queimada.
Assim, ao passo que para a região como um todo o que a defíne é o caráter supletivo da sua produção, internamente à região o alijamento em face do comportamento do mercado é proporcional em cada momento ao isolamento da área e consequente alta nos custos de transporte; o qual é em geral mais caro, comparado com as dístâncias, do que o transporte interregional. São Domingos, nesse regime camponês de superexploração da própria força de trabalho, estaria no limiar de sobrevivência, do ponto de vista do mercado, quanto às condições agora examinadas, ao passo que Itamirim estaria fora; com o que seria especialmente incompatível uma grande euforia produtiva que os tornasse irremediavelmente dependentes do mercado. Fato semelhante parece ter ocorrido na mesma época em áreas de Itupiranga e Jacundá.

Em 1969, especulava-se sobre a urgência da construção de uma estrada em linha reta, de cerca de $80 \mathrm{~km}$, evitando a grande curva do rio. Araguaia, que ligasse Itamirim a São Domingos, para impedir a marginalização daquela área e possivelmente viabilizar a melhoria da estrada, do outro lado do rio, diretamente de Araguatins a Imperatriz. Tentava-se acumular forças no interior das comunidades para a realização desse esforço, que inclusive abriria para a ocupação a área intermediária entre as duas, onde já havia quem se aventurasse timidamente.

$$
* * *
$$

Há outro fator significativo, porém, que passou a atuar no sentido de aumentar a instabilidade da ocupação dos pequenos agricultores. A 5 de janeiro de 1966 entrara em vigor a Lei $n^{\circ} 3.641$, que se constituiu na Lei de Terras do Estado do Pará. Esta Lei foi regulamentada pelo Decreto $\mathrm{n}^{\mathbf{o}}$ 5.780, de 27 de novembro de 1967. Mais tarde, durante o recesso da Assembléia Legislativa do Estado em consequência do Ato Institucional $n^{\mathbf{o}}$ 5, será baixado o Decreto-Lei no 57, de 22 de agosto de 1969, que "Dispõe sobre as terras públicas do Estado e dá outras providências", que, uma vez regulamentado, substitui o previsto na Lei n ${ }^{\circ}$ 3.641. Pará a área em estudo, não parece ter tido grande importância as mudanças ocorridas de 1966 para 1969. O que importa sobremaneira é que, em ambos os casos, substituiu-se o Decreto n 4 $^{\circ} 457$, de 18 de setembro de 1964, que tratava da ocupação provisória de terras devolutas. Não se distribuiu mais titulos provisórios, e q título definitivo exigiria certidões de cartório, demarcações, vistorias, plantas, provas de identidade e de prestação de serviço militar, 
requerimentos etc. Além do mais, tudo agora dependeria de Belém. A consequência concreta disso é que nenhum pequeno lavrador conseguiu o seu titulo. Curioso, então, que a existência, agora, de uma lei de terras no Pará, terá, para o pequeno, lavrador, efeito semelhante ao que se alega ser a consequência da ausência de uma lei de terras no vizinho Maranhão. Somente o frouxo decreto provisório do período 64-66, que permitia que tudo se resolvesse localmente e com pouca burocracia, realmente facilitou a ocupação e sua legalização; o resto mostrou-se desestimulante. Na prática, tanto a inexistência de uma lei de terras quanto a inexistência de uma lei que força o cumprimento de uma série de obrigações burocráticas estimulam a insegurança na ocupação do pequeno lavrador, e lhe superpõe toda uma esfera de decisões e a presença de agentes diante dos quais pouca ação direta de sua parte é eficaz, e que o ameaçam subjetivamente, além de se constituir em potencial numa fonte de manipulações por parte de grupos poderosos tendo ele como alvo.

\section{$* * *$}

No período da euforia dos financiamentos, os comerciantesfinanciadores de São Domingos que não se voltaram decididamente para a produção acabaram tendo diminuída a sua posição relativamente privilegiada. Por um lado, pela substituição de sua atividade financiadora, e por outro, pelo surgimento na mesma ocasião de um único novo comerciante, vindo do Espírito Santo, inteiramente voltado para as atividades comerciais, e com um esquema de compras em Anápolis com que os outros não podiam competir. Diversas pequenas lojas fecharam.

Os pequenos comerciantes-financiadores que se engajaram na produção de início foram também prejudicados, tal como os outros, pelos acontecimentos. Alguns foram, ainda, embaraçados pela passagem problemática à atividade pecuarista na região, especialmente em pequena escala e utilizando crédito bancário, atolando-se em dívidas. Somente uns cinco a seis da camada superior pareceram capazes de transformar a situação a seu favor, e continuar avançando no processo de concentração, uma vez, inclusive, ultrapassada a barreira mais perigosa da pecuária em pequena escala, que só não representou um risco para os da camada inferior do campesinato remediado que não se comprometeram com os empréstimos bancários e preferiram uma acumulação extremamente lenta e sem lucros só compatível com uma estrutura camponesa.
Uma vez conseguido manter certo poder no auge da crise, no entanto, o resto vem como bola de neve. No final de 1969, por exemplo, pela primeira vez aparecem na área duas agências governamentais: a Companhia Brasileira de Armazenamento (CIBRAZEM) e a Comissão de Financiamento da Produção. Essas agências se propõem a garantir o lavrador comprando-lhe o produto por um preço mínimo e armazenando-o. Se no decorrer da entressafra o preço do mercado subir acima do preço mínimo, o lavrador poderá comprar o produto de volta. Em novembro, ao chegarem à área, ofereciam no local um preço mínimo de Cr\$13,00; sem dúvida nenhuma, nas condições vigentes bastante compensador $\mathrm{e}$ inesperado. Isso deveria, aparentemente, significar um rude golpe para os comerciantes. Ocorre que por essa ocasião os produtores já tinham sido obrigados a vender toda a produção aos comerciantes locais, a preços que em casos extremos chegaram a ser de $\operatorname{Cr} \$ 3,00$ e $\operatorname{Cr} \$ 4,00$ o saco. Posteriormente, muitos foram obrigados a comprar de volta pequenas quantidades para a sua própria subsistência, o que se tornava mais difícil à medida que os comerciantes tinham notícia dessa nova possibilidade de venda. Nessas condições, quem se beneficiou dos preços mínimos foram os comerciantes, aumentando ainda maís o seu poder relativo e sua capacidade de concentração.

Os camponeses remediados manobram para utilizar os seus próprios recursos e os da sua comunidade para avançar na sua acumulação. A questão que se coloca agora para eles é a dos limites em que esse esforço é eficaz.

\section{O Ramal e a Nova Exploração Mineral}

A região em estudo, às vésperas do anúncio da construção da rodovia Transamazônica, já atravessava uma fase em que diversos fatores juntavamse no sentido de provocar, como resultado geral, um processo de transformação bastante acelerado. A penetração da frente agrícola era um desses fatores; tal como a pecuária intensiva. Há, porém, pelo menos dois outros - um que se liga à frente e outro bastante independente - que já prometiam vir contribuir decisivamente nesse processo. $\mathrm{O}$ primeiro é o ramal de Marabá da Belém-Brasília e o outro um novo tipo de exploração mineral. Basicamente, o que se pode adiantar são informações e algumas observações prospectivas. Embora isso não possa deixar de ficar carregado de certo teor especulativo, no caso presente parece justificar-se dado o fato 
de que não se referir a eles destorceria o quadro do futuro quase imediato da região.

A estrada PA-70, ramal da Belém-Brasília, que foi aberta ao tráfego em caráter precário em julho de 1969, constitui-se no eixo de uma nova ocupação - na margem direita do Tocantins, sempre menos visada até então pelas frentes regionais - que oferece contraste expressivo com São Domingos. Esse contraste se deve ao relativo isolamento de São Domingos, que vai sendo quebrado num ritmo um tanto lento, em contra posição com a ligação direta do ramal com uma rodovia federal cuja importância já alcançou a consciência nacional.

Logo depois de construída a Belém-Brasília, passou-se a considerar a construção do ramal de Marabá, que ficara afastada da estrada. O ramal viria a ser parte da futura BEL-CAN, estrada que deverá ligar Belém a Jacareacanga, no rio Tapajós. Passaria por terreno desabitado, à margem direita do Tocantins, portanto oposta ao Itacaiúnas, em área que foi por muitos anos domínio dos índios Gaviões ${ }^{37}$; e no seu prolongamento, já do outro lado do Tocantins, atravessaria os campos naturais de Conceição do Araguaia. Chegou-se a abrir uma picada de serviço que o mato acabou por tomar conta. Depois de 1964, abre-se uma nova picada, e passa-se a atacar a construção da estrada. O avanço foi lento, já que de início não foi entregue a empreiteiros, mas realizada pelo Departamento de Estradas de Rodagem do Estado do Pará. Todavia, bem antes de concluída a estrada a faixa compreendida entre as duas picadas, por entre as quais passaria a estrada, numa distância entre si de cerca de $12 \mathrm{~km}$, foi sendo ocupada por lavradores da frente maranhense. No final de 1969, a estrada já estava praticamente toda ocupada, com exceção do trecho correspondente ao castanhal reservado aos índios e daqueles poucos que apresentam absoluta falta de água. A maneira pela qual se deu essa ocupação aumenta de interesse em face dos novos planos rodoviários em execução ou projetados para a Amazônia.

De fato, a estrada não vai até Marabá, pois cruza o rio cerca de $15 \mathrm{~km}$ acima, numa localidade chamada São Félix, que em 1965 possuía apenas três casas de moradores, e para a qual o Censo de 1970 registrará 297 casas e 1.461 habitantes

${ }^{37}$ Ver MATTA em LARAIA e MATTA.
Há um trecho em que a estrada dista apenas sete quilômetros do limite com o Maranhão, e muitos maranhenses entram diretamente por aí, através do chamado Primeiro Cocal. Trata-se de um dos povoados mais isolados do município de Imperatriz, que assim serve de trampolim para o Pará e ganha, por sua vez, novo pólo de atração.

A rodovia entre o Tocantins e a Belém-Brasília tem uma extensão de $220 \mathrm{~km}$. Percorre inicialmente pequeno trecho do município de Marabá, para depois penetrar sucessivamente em São João do Araguaia, São Domingos do Capim e Paragominas. O largo trecho da estrada compreendido em São João desenvolve-se sem quase nenhuma ligação com a sede, da qual dista 10 léguas no meio da mata. A referência é pura e simplesmente a estrada. Antes, porém, que esta desse passagem, já havia lavradores escoando a sua produção para Marabá, pelos afluentes do Tocantins.

A localidade mais importante surgiu de um acampamento do Departamento de Estradas de Rodagem, no interior do município de São Domingos do Capim. No início de 1968 foi batizada de Vila Rondon, dada a presença de estudantes do Projeto Rondon. Em abril de 1969, pouco antes da estrada ser aberta ao tráfego, eram cerca de 200 casas; no final do mesmo ano, já eram mais de 300 .

Isso contrasta com a situação da isolada sede do comprido município de São Domingos do Capim, com a qual pouco contato mantém a Vila Rondon. Situada na confluência dos rios Capim, Guamá e Guajará, a 200 km de Belém, apesar de fundada há quase duzentos anos por um irmão do Marquês de Pombal, possuía na mesma época somente 96 casas, sendo apenas uma de alvenaria. Por isso mesmo, tem-se cogitado da transferência da sede municipal para as margens da Belém-Brasília, entre os quilômetros 84 e $91^{38}$. Trata-se de um caso exemplar das reestruturações que ocorrem particularmente em face da mudança na orientação do sistema de transportes e comunicações em que se passa do primado da navegação fluvial para a predominância do transporte rodoviário - e que carregam consigo ou criam os eixos de produção, enfraquecendo seguidamente a organização administrativa oficial montada no período anterior. 
$\mathrm{O}$ fato de estar ligada diretamente à Belém-Brasília significou, por assim dizer, para essa área, ligar-se a todo o Brasil, sem maiores anteparos. Assim, ao contrário da área de São Domingos, o processo de mudança não ficou "em família", apenas com agricultores maranhenses e fazendeiros de Marabá, o que inclusive lhe imprimiu um ritmo bem diferente. Tal como já vinha ocorrendo em amplos trechos da Belém-Brasília, por aí penetram, algum tempo depois dos lavradores maranhenses, fazendeiros baianos, mineiros e capixabas. Isso é ainda mais facilitado pela ligação próxima da estrada com Paragominas, um dos núcleos mais dinâmicos que surgiram em função da Belém-Brasília e da atração de fazendeiros do Centro-Sul em grande quantidade, e que tende a especializar-se na engorda, buscando-se outras áreas para a cria, entre as quais o ramal.

Os fazendeiros em geral vêm do Sul da Bahia, do Nordeste de Minas Gerais e do Espírito Santo em geral; sendo curioso notar que ainda na década de 50 tanto a Bahia quanto o Espírito Santo possuíam zonas com alto incremento demográfico (ver Introdução). Os baianos são os mais numerosos; em geral da zona Cacaueira ou de Conquista, sendo alguns dos municípios mais mencionados Itabuna, Vitória da Conquista, Itapetinga etc. A seguir vêm capixabas e mineiros, entre estes destacando-se os originários da zona do Mucuri, do Rio Doce e da área contestada com o Espírito Santo, com municípios tais como Teófilo Otoni, Governador Valadares, Serra dos Aimorés, Carlos Chagas etc. Embora o lavrador maranhense tenda a ver os baianos, assim denominados genericamente, como ricos, de fato eles se subdividem em duas camadas. Por um lado, há de fato grandes fazendeiros, mas, por outro, há representantes de camadas médias, muitas vezes de origem urbana, que vão sendo atraídos pelas possibilidades de terras desocupadas, numa espécie de movimento do gênero Marcha para o Oeste. Há, mesmo, uns poucos pequenos lavradores baianos que se misturam à massa de maranhenses. Entre os de origem rural, alega-se como motivo da migração o cansaço das terras no local de origem. Segundo um: "Os terrenos na Bahia estão fracos; um alqueire lá hoje só sustenta 15 reses; aqui dá para 60 ".

Entre os grandes fazendeiros, dos quais uns poucos dos maiores recebem apoio direto da SUDAM, contam-se também algumas firmas gaúchas, paranaenses e norte-americanas, que exploravam, por enquanto, sobretudo a madeira e cujas terras são medidas em várias glebas (a gleba correspondendo a 600 alqueires). Isso, no entanto, ainda se restringe à área perto da Belém-Brasília. As glebas em geral estão mais afastadas da estrada, às vezes até $80 \mathrm{~km}$.

Dentre os baianos, são os médios que têm avançado na direção de São João do Araguaia e Marabá. Enquanto isso, do lado de Marabá, alguns dos seus maiores fazendeiros vão também ocupando terras. Então, tínhamos por todo o ramal, junto à estrada, a presença do pequeno lavrador maranhense que a essa altura vai sendo expulso mais para dentro da mata; logo em seu encalço, pela estrada, vêm os médios fazendeiros baianos; na ponta da Belém-Brasília vão se firmando grandes firmas de fora, e na de Marabá os fazendeiros da terra.

Enquanto estratificação, e que corresponde à ordem inversa de chegada na área, temos:

1) grandes fazendeiros de fora e de Marabá;

2) médios fazendeiros baianos, mineiros e capixabas (espécie de farmers);

3) os lavradores da frente maranhense.

O Governo do Pará tentou garantir a beira da estrada para os pequenos agricultores. Mais uma vez, porém, verifica-se como uma lei só funciona quando existe a possibilidade de fazê-la cumprir mesmo contra tendências que agem em sentido contrário. No caso, os fazendeiros baianos iam ocupando as terras à beira da estrada, comprando as benfeitorias dos maranhenses, e simplesmente pretendendo, quando chegar a hora, pôr cada lote em nome de um parente (alguns inclusive que se encontram nos locais de origem). Aqui, também, o estouro da cooperativa acelerou o processo. $\mathrm{O}$ mais significativo, porém, é que, na vigência da nova lei de terras, o pequeno lavrador não tinha a mínima confiança em sua capacidade de vencer os entraves burocráticos para conseguir o seu título de terras; ao contrário do que ocorria com o fazendeiro baiano. Dessa maneira, tornou-se natural a sua ocupação a prazo curto somente; muito mais do que em São Domingos, pelo fato de muitos não possuírem sequer o título de ocupação provisória, emitido apenas no período $64-66$, e por não chegarem a constituir comunidades exclusivamente camponesas do porte de São Domingos; além da pressão muito maior de compradores concretos, que potencialmente poderiam representar o instrumento de sua expulsão abertamente violenta; 
No lado de Marabá, os lavradores que permanecem já são uma espécie de assalariados disfarçados dos grandes fazendeiros: simplesmente, vendem a produção na folha em troca de um financiamento, já plantando capim junto com o arroz com o compromisso de depois vender a pastagem para o fazendeiro, sem a intermediação de nenhum campesinato remediado de origem na própria frente, que não chegou a se formar.

As relações entre maranhenses e baianos são um tanto tensas. Embora, aparentemente, os pequenos lavradores já venham incorporando o padrão de plantio de pastagem para venda posterior, e muitos considerem sob certos aspectos a sua situação melhor do que a dos de São Domingos, dados os preços mais altos que lhes oferecem por suas benfeitor ias (partindo, portanto, ao que parece, da hipótese de que de qualquer maneira a venda será sempre inevitável), é com certa amargura que isto é feito. E já há vários exemplos que são citados de baianos que tentam "forçar a mão" com maranhenses que não lhes querem vender imediatamente as benfeitorias. Tal como já tem ocorrido na área de São Domingos em alguns casos, exercem pressão fazendo o gado invadir a roça para destruí-la. Em geral conseguem o seu intento, pelo medo que se tem de não cedendo acabar perdendo tudo sem nenhuma compensação. Poucos se animam a recorrer à injustiça, com receio de nada conseguirem e sofrerem represálias piores.

Os baianos em geral quase não têm empregados fixos. Utilizam o sistema de empreitada da região. Muitas vezes empregam aqueles mesmos que lhes venderam as benfeitorias, quando estes não se internam imediatamente na mata (há trechos onde no final de 1969 já havia lavradores a $20 \mathrm{~km}$ da estrada). Os baianos tendem a assumir o papel de modernizadores, inclusive com padrões de maior conforto pessoal, e não aceitam a falta de aplicação no trabalho ocasionada por motivações pouco seculares $^{39}$. Acreditam que se dão melhor com o paraense, mas reconhecem no maranhense um homem trabalhador que, inclusive, faz a limpa da roça de facão, o que sai melhor, segundo eles, do que mesmo na Bahia, onde é feita só de enxada.

A pecuária dos baianos, apesar das semelhanças no fundamental em face das determinações objetivas, apresenta algumas diferenças em relação

\footnotetext{
${ }^{39}$ Um maranhense foi despedido porque deixou de trabalhar um dia por ter sido chamado
} por um cunhado para caçar, o que, segundo ele, não poderia recusar. à de Marabá, entre as quais a de haver junto com a preferência pelo capim colonião, também pelo sempre-verde, ao invés do jaraguá. Também há a intenção mais presente de aproveitar o leite assim que possível. Todavia, no geral as diferenças não parecem muito grandes, adaptando-se os baianos, seguidamente, aos hábitos locais. É preciso dizer que o rebanho dos baianos ainda está no início de sua formação.

O fundamental a fixar é como no ramal rapidamente se cristalizou o padrão do binômio diacrônico pequena lavoura-pecuária intensiva, que em São Domingos e arredores, através dos anos, tem sido vislumbrado como uma tendência possível, mas que sofre toda uma série de marchas e contramarchas, de tal forma que baseados no mero jogo de forças econômicas é difícil prever o resultado final. No ramal, tudo se passa de modo mais simplificado e claro, revelando o peso enorme de forças econômicas supralocais que se expandem. Marabá é uma das poucas áreas da Amazônia onde uma elite local pode aproveitar-se do movimento e integrar-se nele, inclusive com finalidades menos especulativas do que ocorre com as grandes firmas vindas de fora. Certamente, no entanto, daí emergirá, no longo prazo, algo inteiramente novo para Marabá.

A partir de 1970 uma linha de ônibus fará a ligação Marabá-Belém em 13 horas. A PA-70 terá provocado uma alteração radical na estrutura de comunicações com o Norte, que precede a alteração com o Sul que se dará com a Transamazônica.

$$
* * *
$$

São Domingos e a PA-70 representam exemplos de dois tempos diferentes na sobredeterminação local de forças produtivas geradas no âmbito de sistemas envolventes, que transformam o quadro da região. Há, porém, um exemplo, ainda embrionário, do que virá a ser um terceiro tempo, que vai sendo gerado de uma maneira praticamente autônoma de tudo o que vem ocorrendo na região. É como que um "segundo reverso da medalha".

Uma empresa subsidiária da poderosa United States Steel passou a pesquisar há alguns anos importantes jazidas de ferro na serra dos Carajás, situadas no interior do município de Marabá, na direção do Xingu, em área isolada, a 700 metros de altura e trinta minutos de vôo da cidade de Marabá. Os trabalhos de prospecção revelaram tratar-se de jazidas pelo menos tão 
importantes quanto as do quadrilátero ferrífero de Minas Gerais, com o que o Brasil passaria do terceiro para o primeiro lugar no mundo em reservas de ferro. O teor de pureza do ferro é dos mais altos. Além do ferro, descobriuse também manganês, estando avançados os trabalhos de prospecção.

Feita a avaliação das reservas de ferro, 'no início de 1970 formou-se uma companhia através de uma associação em que $51 \%$ das ações ficaram nas mãos da Companhia Vale do Rio Doce e o restante com a firma de origem norte-americana. Calcula-se que vários anos serão gastos na realização dos investimentos necessários ao início da exportação do minério - que só pode ser em grande escala - entre os quais se incluem uma linha de estrada de ferro na direção de Belém ou do litoral maranhense numa extensão de cerca de $900 \mathrm{~km}$, além de cais apropriado, ou uma estrada até o Tocantins combinada com extensas obras de regularização do curso do rio.

Trata-se de um investimento de capital que já alcançou muitos milhões de dólares, embora desse total relativamente pouco tenha ficado até agora na região. As autoridades municipais não são consultadas sobre o que vai ocorrendo, as negociações sendo realizadas em altas cúpulas, absolutamente inacessíveis - sem nenhuma exigência de mediação local e sem serem sequer perceptíveis com clareza ao nível local as quais envolvem grandes interesses capitalistas internacionais.

Já chegaram a ocupar na fase de prospecção e avaliação das jazidas cerca de 400 homens, antecipando o que ocorrerá em escala maior uma vez se prossiga o projeto: a criação de um mercado de trabalho e de um mercado consumidor privilegiado. Afora isso, serão obrigados a aplicar, tal como a ICOMI no Amapá, uma parte de seus lucros na região; que embora percentualmente pequena, em termos absolutos será de grande vulto. Uma exploração mineral em grande escala não traz necessariamente por si um clima de prosperidade. Porém, se levarmos em conta que não se trata mais de uma região isolada, nem velha e decadente, mas de uma região que por muitos outros motivos está em expansão, e, nos anos por vir, exatamente na direção do Xingu, é de se imaginar as consequências que advirão.

Por enquanto não se pode fazer muito mais do que especular e examinar casos semelhantes, sem muito o que encaixar no quadro atual da região. Todavia, trata-se de fato bem concreto, e o espantoso é que sem ter uma história local, tal como a que viemos traçando neste trabalho, poderá, de repente, alterar o panorama geral de um modo bastante radical. Isso tudo, sem dúvida, será do maior interesse no exame dos efeitos da ação do capitalismo monopolista em regiões subdesenvolvidas, que modifica totalmente a escala de análise, e, no caso particular, faz, inclusive, aparecer em toda a sua nitidez a natureza absolutamente palootécnica de qualquer exploração mineral anteriormente realizada. 


\section{A TRANSAMAZÔNICA}

\section{A Estrada}

No hoje 16 de março de 1970 a Presidência da República distribuiu comunicado em que anunciava várias obras rodoviárias na Amazônia e no Brasil Central para o período 1970-74, "tendo como peça básica a Rodovia Belém-Brasília". Entre elas o prosseguimento do asfaltamento do trecho Anápolis-Porangatu da dita estrada, o prolongamento até Rio Branco e a fronteira com o Peru da estrada Cuiabá-Porto Velho, o término da estrada Porto Velho-Manaus, a implantação de uma estrada. Cuiabá-CachimboSantarém, e "a construção de estrada pioneira ligando o Nordeste à Amazônia".

Quanto a esta última, segundo o comunicado, "Partindo de conexões com a Rede Rodoviária do Nordeste, essa rodovia atravessará a BelémBrasília, na altura de Marabá (grifo nosso), às margens do Tocantins, para, em seguida, cruzar as bacias do Xingu e do Tapajós e alcançar Humaitá, onde se encontrará com a estrada Porto Velho-Manaus. Com seus 1.750 $\mathrm{km}$, a estrada, que se poderá chamar de transamazônica, conectará os pontos terminais dos trechos navegáveis dos afluentes meridionais do rio Amazonas e será uma vereda aberta ao nordestino para a colonização de enorme vazio demográfíco e o inicio da exploração de potenciais até então inacessíveis" (Jornal do Brasil, 17/3/70).

Com a construção de uma série de estradas novas e o aproveitamento e melhoria de estradas existentes, a estrada propriamente transamazônica seria ligada ao Nordeste.

Iniciada a construção da estrada no final de 1970 simultaneamente em trechos diversos, já em outubro de 1971 era entregue ao tráfego o trecho que atravessa a área de nosso estudo e que vai do rio Araguaia, do lado do Pará (a partir de local denominado Porto da Balsa ou Porto Jarbas Passarinho), até Marabá, passando a 5 quilômetros desta cidade. Do outro lado do rio Araguaia, em Goiás, de um ponto situado 8 quilômetros acima de Araguatins (antiga São Vicente) abria-se também a ligação com a Belém-Brasília, com a construção de estrada nova e o aproveitamento do ramal que ligava Tocantinópolis (antiga Boa Vista) à localidade de Estreito, no limite entre Goiás e Maranhão, onde a Belém-Brasília atravessa o rio Tocantins.

O trecho inaugurado entre Marabá e o Araguaia (Porto da Balsa) tem uma extensão de 126 quilômetros. No quilômetro 68 um acampamento da firma empreiteira deu origem a um aglomerado que cresce rapidamente (Dacaba).

São Domingos do Araguaia também serviu de acampamento de novembro de 1970 a fevereiro de 1971 para a firma empreiteira do trecho. Eram mais de duzentos homens, criando um movimento nunca visto no povoado. Inaugurada a estrada, esta veio a passar a 4,5 quilômetros de São Domingos, cruzando a estrada construída em 1961 entre S. Domingos e Apinagés (ver cap. 7).

A precária estrada aberta em 1969 através do esforço local ligando Marabá a São João do Araguaia encerrou a sua utilidade; não sem antes servir aos construtores da estrada para transporte de homens e material.

Quase toda a estrada neste trecho passou por dentro das fazendas de gados abertas nos últimos anos a partir de Marabá, com o que o trabalho de desmatamento foi muito reduzido.

Em janeiro de 1972 a estrada já estava dando passagem precariamente até Altamira (no Xingu) e mesmo Itaituba (no Tapajós). Todavia, o trecho efetivamente trafegável se interrompia pouco depois de Jatobal, onde um ramal em construção de Tucuruí encontra a estrada principal.

O fluxo inter-regional pela estrada, vindo diretamente do Nordeste, ainda era pouco maior do que o anterior. A ligação Porto Franco-Grajaú completar-se-ia no começo de 1972, e a nova estrada entre Carolina e Balsas também não estava concluída. Fundamentalmente, o fluxo novo observável se devia a um remanejamento de pessoas ainda na própria região e suas imediações. É assim que se verificava o avanço na direção da Transamazônica de lavradores anteriormente estabelecidos próximos à Belém-Brasília. O movimento maior partia justamente dos dois municípios no Norte cujas sedes conheceram maior crescimento e prosperidade com o advento da Belém-Brasília: Imperatriz e Araguaína. 
Em outubro de 1971 estabeleceu-se uma linha de ônibus ligando Araguaina a Marabá e outra entre Porto da Balsa e Marabá. O movimento que se estabeleceu foi imediatamente enorme, a oferta criando a procura. Especialmente no caso da ligação Porto da Balsa-Marabá, utilizada fundamentalmente por moradores da própria área que se deslocavam em suas atividades de compra e venda, podendo retornar a suas moradias no mesmo dia ou no dia seguinte.

Os moradores da área de São Domingos podiam, deslocando-se até a estrada principal, utilizar-se do ônibus Araguaína-Marabá. Porém o transporte preferencialmente utilizado era o ônibus Porto da Balsa-Marabá, que se desviava da estrada principal para vir recolher passageiros em São Domingos. Os ônibus viajavam lotados. Na verdade, o trecho da linha de maior movimento era justamente entre São Domingos e Marabá. Por isso mesmo, pensava-se em colocar um ônibus exclusivamente na linha São Domingos-Marabá. Com isto, dar-se-ia maior vazão ao movimento, e permitirse-ia que os moradores de São Domingos chegassem a Marabá mais cedo, podendo aproveitar melhor a parte da manhã para as suas transações comerciais antes que as lojas se fechassem às $11: 30 \mathrm{~h}$.

Até 1969 uma viagem de São Domingos até Marabá exigia percorrer a estrada de São Domingos até Apinagés a pé, montado ou pegando um lugar num jipe ou caminhão eventual. Se se conseguisse um transporte por rio em Apinagés até às $15 \mathrm{~h}$, com cerca de mais 3 a 4 horas de transporte por rio chegava-se a Marabá (na volta a subida levava de 8 a 9 horas). Depois das $15 \mathrm{~h}$, já não era possível navegar, pois o sol se põe exatamente na direção do curso do rio, dificultando a visão dos pilotos e tornando a navegação muito perigosa nas corredeiras e canais. Quem não conseguisse transporte até essa hora, o que era comum, tinha de pernoitar numa palhoça na beira e aguardar o dia seguinte.

A partir de 1969, com a estrada Marabá-São João, passou-se a realizar a viagem em 3 horas de jipe ou 6 horas de lotação ${ }^{1}$.

${ }^{1}$ Por toda a parte onde a frente agrícola ganhava maior impulso ocorriam fatos semelhantes. De Araguatins, por exemplo, levava-se cerca de 36 horas até Imperatriz e a Belém-Brasília (descendo o Araguaia até a foz para depois subir o Tocantins). Depois construiu-se uma precária estrada só utilizável no verão ligando Araguatins a Bela Vista (em frente a Imperatriz), bem como outra na direção de Tocantinópolis, que se levava cerca de 15 horas para atravessar. Ambas também são substituídas pela Transamazônica.
A partir de outubro de 1971, com a Transamazônica, a viagem de São Domingos a Marabá reduziu-se a um trecho de $56 \mathrm{~km}$, percorridos em 1 hora de ônibus ao custo somente de $\mathrm{Cr} \$ 2,00$.

Uma minoria também já vai utilizando as novas estradas para percursos maiores, surgindo muitos projetos de rever parentes e a terra de origem $^{2}$, ir a Belém etc.

\section{Os Efeitos}

Com tudo isto revela-se simultaneamente a enorme transformação ocorrida com o advento da estrada, bem como o fato de que nos anos anteriores já estavam ocorrendo alguns desenvolvimentos em direção semelhante ${ }^{3}$. Particularmente, é de se notar como a frente agrícola e o seu avanço sempre estiveram associados à abertura de estradas e caminhos afastando-se da beira, buscando a penetração e a ligação com as vias principais de comunicação e transporte.

As novas ocorrências, onde se somam a Transamazônica - que efetivamente transforma a região em porta de entrada para a Amazônia continental - a P A-70, o aparecimento de firmas do Sul e órgãos governamentais, a exploração hoje certa de ferro na serra dos Carajás, a próxima instalação de uma unidade do Exército em Marabá e a presença do campus avançado da Universidade de São Paulo (Projeto Rondon), fazem com que antigos projetos em torno dos quais há longos anos se especulava na região ganhem maior viabilidade. Entre estes, a ideia de regularizar-se o curso do rio Tocantins para facilitar a navegação, de que já se falava pelo menos desde $1809^{4}$; a construção de uma usina hidrelétrica na Itaboca ou

${ }^{2}$ Foi muito comentada a viagem de um comerciante local que foi rever a família no Crato (Ceará) e só gastou de transporte $\mathrm{Cr} \$ 54,00 \mathrm{em}$ cada sentido. Outro foi rever a irmã que não via há 16 anos, residente além de Tocantinópolis, e gastou somente 5 horas de viagem. De maneira geral na região também as ligações comerciais com o Nordeste, que se haviam reduzido em face das ligações com o Sul estabelecidas com a Belém-Brasília, parecem ganhar novo impulso: diversos caminhoneiros têm vindo do Nordeste e, inclusive, por vezes aproveitam para realizar fretes de curta distância na própria região.

Como já vimos, o incremento demográfico ocorrido na década de 50 na antiga Zona do Itacaiúnas foi de $76,0 \%$. O Censo de 1970 revelou ter sido de $89,7 \%$ o incremento ocorrido na década de 60 na microrregião de Marabá.

4 "Manda o Governador prover o Ouvidor de São João das Duas Barras da Capitania de Goyaz Joaquim Theotonio Segurado das ferramentas precisas para esvanecer no rio 
numa das quedas d'água do Itacaiúnas; o beneficiamento local da castanha, em vez de seu transporte em bruto para Belém, bem como o do babaçu e a abertura de serrarias; a construção de uma ponte sobre o Itacaiúnas, ligando Marabá ao bairro do Amapá e ao aeroporto, agora necessária também para ligar o trecho Araguaia-Marabá da estrada ao trecho seguinte na direção de Itupiranga.

Finalmente, chega-se a questionar mais uma vez a própria localização de Marabá, sujeita a enchentes. Como vimos, essa localização fora determinada, na época de sua fundação, pela importância dos rios para o comércio e transporte (ver cap. 4). Enquanto o primado dos rios se manteve, foram sem consequência todas as especulações de transferência. Hoje, a situação é outra, pois instala-se o domínio dos eixos rodoviários. Todavia, apesar dos noticiários dos jornais, que assumindo uma ideologia de heróis civilizadores ignoram a existência já de uma cidade de m.ais de 16 mil habitantes, provavelmente não se tratará de pura e simples transferência, mas do desdobramento da cidade 'na beira da Transamazônica, mais afastado do rio, tal como ocorreu espontaneamente em Imperatriz com o advento da Belém-Brasília. Com o tempo, é possível que essa nova área urbana venha a suplantar a antiga.

Mais remotamente, reacende-se um movimento, que $\mathrm{cm}$ épocas anteriores tivera Porto Nacional e Imperatriz como focos, de criação do Estado ou Território do Tocantins. Sua capital, agora inconteste depois de terminado um período de declínio relativo, no decênio após a abertura da Belém-Brasília que não a alcançara, seria Marabá 5 .

É possível que mesmo projetos que só em sonhos eram imaginados viáveis, como a construção de uma siderúrgica para aproveitamento do ferro e do manganês na região, se realizem.

$* * *$

A principal impressão que fica da construção da Transamazônica é que representa o coroamento do processo de quebra do isolamento da

Tocantins o obstaculo mais difícil dos tres canaes da cachoeira da Itaboca, que em corpolencia he a mais extremosa das que despenha o dito rio" (BAENA, p.282).

${ }_{5}^{5}$ Outra antiga reinvidicação, esta especificamente de Marabá, já foi realizada: a partir de 1971 Marabá é sede de bispado. região ${ }^{6}$, que já vinha sendo erodido paulatinamente nos últimos anos (ver caps. 6 e 7). Apesar da castanha ser um produto essencialmente de exportação, que exigia comunicação com Belém, essa comunicação constituia-se tradicionalmente num oligopólio, e se dava com elementos comprometidos com o mesmo sistema em nível estadual.

O sistema de exploração montado em Marabá exigia esse isolamento, que permitia a prática quase aberta da violência, quer na apropriação de terras, quer na manutenção do sistema de exploração da mão-de-obra, colorindo de modo característico todas as relações em geral. Com raras exceções, a justiça e a política amoldavam-se à situação, e constituíam, mesmo, um seu instrumento.

Por outro lado, essa situação permitia também a inexistência de uma concorrência maior ao domínio estabelecido.

Conforme declarou ao ser entrevistado um dos homens ricos de Marabá, demonstrando os novos usos de uma ideologia de pioneiro em uma nova situação em que a região não é mais vista nacionalmente como mero campo de exploração de recursos naturais e mão-de-obra, numa espécie de colonialismo interno, mas também como campo para a aplicação de capitais:

Os verdadeiros bandeirantes são os marabaenses. Fizemos tudo nessa terra, sem apoio. O pessoal do Sul, quando chega aqui, se espanta, porque pensava encontrar a mata virgem. Construíram a Transamazônica por dentro das fazendas, na maior facilidade, recebendo dinheiro por desmatamento e deslocamento que não fizeram.

Agora vem chegando esse pessoal do Sul para abrir negócios. Mas quem fez tudo aqui fomos nós. É claro que para o povo em geral as coisas vão melhorar, não vai haver só meia dúzia de ricos mandando aqui, o truste. Mas eu e outros como eu vamos ser prejudicados.

Todavia, o fato é que também para os ricos de Marabá a estrada abre novas possibilidades, variando de caso para caso a capacidade de adaptar-se

${ }^{6}$ Perguntado se venderia as suas terras a pecuaristas vindos de fora, um lavrador respondeu: "Depois desses anos de sacrifícios agora que isto aqui é Brasil, eu não vou me meter de novo dentro do mato." 
a um novo sistema e integrar-se aos novos empreendimentos; conforme, aliás, já podia ser verificado nos últimos anos (ver cap. 6).

No entanto, não há dúvida de que a abertura da estrada teve vários efeitos antioligopolistas. Mesmo antes da Transamazônica, por exemplo, em 1970, com a abertura da P A-70 que pela primeira vez ligou Marabá ao mercado nacional por via terrestre, estabeleceu-se em Marabá um comprador de castanha vindo de São Paulo. Dessa maneira, pela primeira vez surgiu a possibilidade de uma colocação mais significativa de castanha no mercado interno e de tal forma que foge ao controle dos grupos exportadores de Belém. Os donos de castanhais menores, bem como os subarrendatários, que estavam sendo cada vez mais exprimidos pelos grupos maiores, ganharam, pelo menos provisoriamente, um novo alento. Talvez seja por causa de desenvolvimentos como estes que o grupo exportador de Belém tradicionalmente mais ligado a Marabá comprou para explorar diretamente o maior castanhal de Marabá por Cr\$ 5.000.000,00.

Além disso, de maneira geral a chegada diária de caminhões de mercadorias vindos do Sul pela estrada (que já haviam começado a vir pela PA-70 antes mesmo da Transamazônica, mas em volume menor e dando uma grande volta, já que esta estrada se desenvolve no sentido de Belém) tem barateado o custo de vida. Isso se deve inclusive ao fato da vinda dos caminhões ter facilitado a venda por parte de pequenos comerciantes que antes dependiam para a manutenção do seu comércio do apoio dos grandes comerciantes, que fixavam os preços do mercado e controlavam os canais de comercialização ${ }^{7}$.

Também para a pequena agricultura houve consequências semelhantes, já que os caminhões do Sul vêm comprar diretamente o arroz, em vez de depender da intermediação dos beneficiadores e comerciantes de Imperatriz. A maneira pela qual se deu o escoamento da produção serviu

${ }^{7}$ Em São Domingos isso estimulou a abertura de pequenas biroscas, que anteriormente já existiam em grande número, sendo aviadas por comerciantes de Marabá ou, cada vez mais, pelos seis ou sete maiores de São Domingos. Hoje podem comprar a crédito diretamente dos caminhões (num prazo correspondente ao intervalo entre duas viagens: cerca de trinta dias), e já são mais de quarenta, chegando a prejudicar o comércio maior e mais estável. Com o tempo a maioria provavelmente fechará, dado o reduzidíssimo volume de negócios de cada um de per si e o aumento nos impostos e na fiscalização, que os vai obrigando a legalizarem a sua situação. Servem às vezes como justificativa à permanência em São Domingos, em vez do deslocamento para o centro, onde se encontra a roça do lavrador. para confirmar claramente o caráter supletivo dessa produção para o mercado nacional, a posição central da produção do Brasil Central e as posições simétricas opostas da produção gaúcha e da produção maranhenseparaense, bem como o papel dos comerciantes locais. A ocorrência de uma longa seca fez com que a safra de arroz do Brasil Central em 1971 fosse sensivelmente menor do. que o previsto. Com isso, teve-se que apelar para o arroz gaúcho na tentativa de suprir o mercado interno com a parte da sua produção normalmente destinada à exportação. Todavia, ocorre que essa parte da safra gaúcha destinada à exportação já estava comprometida. Os jornais noticiaram que nestas circunstâncias o país foi obrigado a importar arroz italiano. O que foi menos falado, todavia, é que deu-se também verdadeira corrida atrás do arroz maranhense-paraense.

No caso da área de São Domingos, utilizando-se da Transamazônica, ainda não inaugurada, a partir de setembro (1971) inúmeros caminhões de Anápolis e São Paulo chegaram ao povoado oferecendo preços bem acima do esperado. Num ano em que o preço mínimo oficial era de Cr\$20,00 o preço oferecido em São Domingos nos últimos meses do ano chegou a $\mathrm{Cr} \$$ 35,00 .

Maís uma vez, porém, os grandes beneficiados por esta situação foram os comerciantes locais e camponeses remediados da camada superior, que já haviam comprado praticamente toda a produção de arroz da massa de lavradores na folha por $\mathrm{Cr} \$ 7,00$ a $\mathrm{Cr} \$ 9,00^{8}$.

$* * *$

De qualquer forma, todavia mesmo sendo os benefícios maiores no momento canalizados pela camada superior restrita de camponeses remediados e comerciantes locais, a médio prazo. a estrada pode oferecer condições de escoamento para .a produção de que poderão se beneficiar, se não todos os lavradores (dada 'uma série de problemas, entre os quais a dificuldade de livrar-se da dependência do financiamento dos comerciantes locais), pelo menos uma camada relativamente ampla. Aparentemente, entre a camada superior dos camponeses remediados e comerciantes locais e a

${ }^{8}$ Os comerciantes alegam só poder comprar por preço tão baixo por causa dos juros que têm de calcular sobre o empréstimo, em termos aproximados (já que não podem antecipar o preço exato que o arroz alcançará). Todavia, aplicando-se uma taxa de juro normal sobre os preços oferecidos, mesmo levando em conta somente o preço mínimo vê-se que esta explicação é insuficiente, tratando-se, efetivamente, de um alto negócio. 
massa de pequenos camponeses, vai-se desenvolvendo a camada aos que conseguem evitar a venda antecipada na folha de toda ou boa parte da produção, e com isso asseguram um saldo com o qual podem vir a comprar lenta e reduzidamente algumas cabeças de gado (sem auxílio de banco em geral), sem chegar a substituir a lavoura como atividade principal. Constituem hoje o campesinato economicamente viável, juntamente com os que alugam pasto aos fazendeiros, recebendo o pagamento em partilha, ao mesmo tempo que mantêm a própria lavoura ${ }^{9}$. Atualmente devem atingir cerca de 20\%; do total de lavradores, sendo que não mais do que $10 \%$ desse total, aí incluído, utilizam hoje mão-de-obra extrafamiliar $\mathrm{cm}$ caráter permanente.

\section{A Colonização}

Na área de São Domingos o problema de terras está se tornando mais difícil. Não existem mais extensas faixas de terra livre próximas a São Domingos, e alguns dos mais antigos lavradores começam a ensaiar o plantio em capoeira (com bons resultados até o momento) ${ }^{10}$. Por isso diminui a capacidade de absorver novos lavradores, que terão de se deslocar mais para adiante para encontrar terras. Como diz um deles:

O negócio pro chegante está complicado. Pobre tem que andar, tem que acompanhar o movimento. Quem já fez já fez, quem não fez, não faz mais

No entanto, continuam a chegar lavradores, que vão plantando, como nunca ocorrera na história de São Domingos, em terra alheia; seja por favor (especialmente entre parentes e amigos do mesmo local de origem), seja num sistema de partilha ${ }^{11}$.

${ }^{9}$ A qual, aliás, é necessária de início, para conseguir o dinheiro suficiente para comprar o arame com o qual se cercará o pasto.

${ }_{10}$ Curiosamente, para alguns dos mais antigos povoadores (inclusive Serafim, o velho fundador de Das Latas), a situação se tornou particularmente difícil, por não se terem, ao contrário da maioria, se preocupado em regularizar a posse da terra, já que acostumados com a terra livre e abundante, têm dificuldade em entender o seu valor e encará-la como um bem limitado.

${ }^{11}$ O número desses indivíduos aumentou consideravelmente nos últimos meses de 1971 dado um problema de terras ocorrido no município de Lago da Pedra (Maranhão), onde um indivíduo conseguiu um título sobre uma terra ocupada há muitos anos por uma massa de lavradores, e vendeu-a a um grupo do Sul que iniciou um projeto pecuarista utilizando um
Os castanhais do município estando hoje reduzidos a apenas pequenos grupos de árvores ${ }^{12}$, aumenta a pressão no sentido de retirar castanha às escondidas dos castanhais de propriedade, exigindo grande vigilância da parte de seus responsáveis e provocando choques que pelo menos em um caso redundaram em morte na safra 70-71. Aumenta também o número de lavradores que tentam se estabelecer para cultivar em terrenos considerados de propriedade, os quais ocupam a maior parte da beira da Transamazônica nesse trecho.

Todavia, existem bolsões de terra livre, e áreas já ocupadas que no entanto estavam tendendo, antes da estrada, a expulsar parte de seus habitantes por estarem se mostrando dificilmente viáveis para uma produção voltada preferencialmente para o mercado. Tal era o caso de Palestina e Itamirim, para onde, como vimos no capítulo anterior, a saída tal como era vista pelas próprias comunidades seria a abertura de uma estrada por esforço próprio, partindo de São Domingos na direção do Araguaia e além. A Transamazônica veio a passar a apenas $7 \mathrm{~km}$ de Palestina e a $2 \mathrm{~km}$ do aglomerado de ltamirim, invertendo totalmente a situação exatamente no sentido desejado e colocando a área em posição privilegiada.

$$
* * *
$$

Apesar de todos esses desenvolvimentos, o INCRA, recém estabelecido na região, não coloca como prioridade o apoio aos lavradores estabelecidos espontaneamente. Praticamente todo o seu esforço está concentrado no projeto de colonização em Itupiranga, onde encontrou maior extensão contínua de terras ainda não ocupadas. Em 1971 conseguiram assentar 200 famílias no projeto, sendo a maioria já residente na própria região. Em 1972 pretende-se assentar mais 1.000 famílias.

Supondo-se uma média de 6 pessoas por família, isso no final significará, caso seja bem sucedido, a colocação de cerca de 7.200 pessoas. De acordo com o Censo, em meados de 1970 - portanto, mais de um ano antes da inauguração do trecho da Transamazônica - já existia na microrregião de Marabá uma população de 33.558 no quadro rural somen1e

pessoal em número reduzido vindo de fora e beneficiando-se dos incentivos fiscais da SUDENE. Só para São Domingos deslocaram-se em consequência cerca de cem pessoas.

${ }^{12}$ Não só por causa da apropriação por fazendeiros, mas também por causa de lavradores que ocupam as terras e realizam a queimada, destruindo as castanheiras. 
(FIBGE, 1971c, p. 31). É de se notar que, além desse total, parte considerável dos 24.276 residentes no quadro urbano certamente dedicavam-se a atividades rurais ${ }^{13}$. Dessa data em diante a população só fez crescer.

Dados os custos envolvidos nesse gênero de colonização, é assim bastante provável que a entrada de pessoas na área vá suplantar de muito a capacidade de absorção, nos seus desdobramentos futuros, pelo projeto do INCRA, que aparece, portanto, como possivelmente inadequado em sua finalidade declarada de absorver um contingente ponderável de mão-deobra nordestina.

A par disso, o balanço da experiência brasileira em matéria de colonização, particularmente a da SUDENE no próprio Maranhão, é francamente negativo. $\mathrm{Na}$ região de Marabá, toda a ideologia de desconfiança dos lavradores que acompanha a possibilidade de trabalhar como empregado é refletida num grande receio das intenções do INCRA, que pretenderia, segundo a maioria, em última análise tirar a terra dos lavradores e pô-los sob o cativeiro ${ }^{14}$.

Aparentemente, a concepção de colonização tal como é praticada implica uma pretensão de controlar o processo de povoamento em que a onipotência pode aproximar-se perigosamente da impotência. Mesmo bem sucedida dentro de seus limites, o que é duvidoso, a colonização provavelmente levaria à formação de uma camada relativamente privilegiada de colonos no meio de um mar de povoamento espontâneo que se daria à sua revelia.

Uma política de povoamento de massas teria necessariamente de buscar realizar objetivos menos ambiciosos, porém em escala bem maior, sem fixar a priori a direção exata que o processo tomaria, mas contentandose em garantir as condições mínimas (como auxílio na construção de estradas vicinais, créditos limitados para facilitar a simples manutenção do lavrador até a colheita, preços mínimos, assistência agrícola, à saúde e escolar etc.), e orientando os lavradores, sem que sintam sua autonomia

${ }^{13}$ De acordo com a SERFHAU, somente $14,91 \%$ da população do município de Marabá dedicam-se a atividades não-rurais (ver SERFHAU).

${ }^{14}$ É curioso, a propósito, lembrar a analogia com as observações de COUDREAU (ver cap. 3) feitas no final do século passado sobre o mal sucedido Burgo do ltacaiúnas e as resistências ao trabalho "en grande famille", sob uma hierarquia e uma direção. ameaçada, para a racionalização possível a cada momento ${ }^{15}$. Sobretudo, seria preciso garantir efetivamente a posse da terra.

Esses objetivos, aparentemente mais modestos, podam ter consequências bastante maiores do que se pode pensar à primeira vista. Vimos, por exemplo, no capítulo anterior, que um dos principais motivos, senão o principal, pelo qual muitos lavradores não conseguem deixar de vender antecipadamente a sua colheita, tornando altamente problemática a médio prazo a continuação da sua atividade, prende-se a despesas com doenças. Assim, uma simples assistência médica eficiente para os problemas mais comuns (malária, gripe, complicações pós-natais, doenças gastrintestinais etc.) poderia ter consequências da maior importância no esforço de formação de uma classe estável de pequenos agricultores. Mas se os recursos forem concentrados em estruturas fechadas de projetos delimitados e elaborados, constituindo como que reservas, isto será difícil ${ }^{16}$. Um caminho de que já há indícios é que na tentativa de mostrá-lo viável, os objetivos do projeto sejam aos poucos de tal forma rebaixados, que no final pouco haverá a distingui-lo do que está fora do projeto, a não ser o seu autoritarismo endógeno, nas condições brasileiras, dada a impossibilidade prática de participação do tipo de colono que prevalece no processo decisório central, o que marca o trabalho, independentemente da vontade dos técnicos. Mas Com isso, pela tentativa de criar as condições para um supercontrole, ter-se-á deixado o processo principal ao sabor de puras forças econômicas, com resultados difíceis de prever. Nos vales úmidos do Maranhão, o resultado espontâneo parece vir sendo, até agora, a gradativa e implacável substituição da lavoura pela grande pecuária ${ }^{17}$, com 0 consequente transbordamento de massas deslocadas para o Maranhão Ocidental e o Pará $^{18}$, e um empobrecimento dos vales úmidos pela

${ }^{15}$ A ideia, por exemplo, de substituir a lavoura do arroz por culturas permanentes para proteger o solo só será possível após um cuidadoso estudo do mercado e à medida que se torne viável uma comercialização mais rápida e sofisticada, que os cereais não exigem.

${ }^{16}$ É verdade que a ACAR pretende ter uma atuação mais ampla em moldes semelhantes aos que indicamos. Todavia, o que se coloca é qual a política que predominará, dando o sentido ao conjunto e determinando a alocação de recursos.

A SUDENE aprovou até dezembro de 197124 projetos não industriais no Maranhão. Todos são pecuaristas (informação do escritório da SUDENE em São Luís).

${ }^{18}$ A explicação de que isto se deve ao sistema de queimada que esgota as matas e empobrece o solo não parece suficiente. Apenas poderia explicar a não-absorção de novos contingentes. $\mathrm{Na}$ área de São Domingos o tamanho médio dos terrenos é em torno de 25 quadras (cerca de 
diminuição do movimento no comércio local e uma tendência a não reinvestir o capital na região. Na PA-70 o processo mostrou-se ser ainda mais rápido. Em 1972, menos de três anos depois de aberta, já não há praticamente mais lavradores na beira da estrada, tendo sido deslocados para o interior, invertendo a posição inicialmente pretendida de lavradores junto à estrada e pecuaristas mais afastados. A pura determinação formal de que assim deveria ser não bastou, na ausência de medidas concretas para fortalecer a posição do pequeno lavrador.

Se o INCRA encarar de frente o problema global da terra, revelar-seá na região de Marabá uma quantidade imensa de terras que podem ser abertas à ocupação dos lavradores, e que hoje estão na posse dos grandes donos de castanhais e fazendas. Como vimos no capítulo 6; os castanhais e fazendas ocupam seguidamente área muito maior do que a que lhes foi originalmente reservada. Se a discriminação de terras anunciada for levada às últimas consequências, o volume de terras liberado tornará a região de Marabá capaz de absorver ainda um grande contingente de mão-de-obra ${ }^{19}$.

Nas regiões mais despovoadas da Transamazônica na direção do Xingu e adiante, os riscos na aplicação da política de colonização e a questão de terras podem ser menos evidentes a curto prazo; mas acabarão por se revelar se não houver uma preparação adequada para um povoamento de massas. A alternativa depende de que as agrovilas sejam efetivamente multiplicadas e entendidas, não como centros de comando de colônias estreitamente delimitadas, mas como pontos de apoio seguro de estruturas abertas dentro de limites mais amplos, a fim de que se possa estabelecer o equilíbrio que permita, embora sob a dominância em última análise de um sistema capitalista presidido pelo Estado, o espaço necessário para o desenvolvimento de um setor camponês.

100 hectares). Planta-se em média 1 quadra por ano. Assim, levar-se-iam 25 anos para acabar com a mata. Sabendo-se que até o terceiro ou quarto plantio pelo menos não há diminuição de produtividade, pode-se imaginar a possibilidade de plantar durante 75 a 100 anos sem problemas dessa ordem, supondo não haver nenhuma modificação técnica nesse período.

${ }^{9}$ Toda a questão de regularização da posse está agora entregue ao INCRA, que estando no local poderá criar um sistema com um mínimo de burocracia que tenha efeito estimulante semelhante ao da lei de ocupação provisória de terras do Estado do Pará de 1964.

\section{São Domingos do Araguaia}

De acordo com dados colhidos pela SUCAM (através da Campanha da Malária), no final de 1971 a sede do município de São João do Araguaia possuía 160 casas, Apinagés 221 e São Domingos do Araguaia 525.

A superioridade de São Domingos no conjunto do município já é evidente. Em 1971 instalou-se a primeira beneficiadora de arroz, e outra seria inaugurada em 1972. Com a Transamazônica a sua vantagem sobre os demais núcleos aumentou, apesar da construção de um ramal de $13 \mathrm{~km}$ pouco justificável economicamente ligando a sede do município à estrada. Diversos dos comerciantes maiores de Apinagés têm transferido as suas residências e os seus negócios para a área de São Domingos. A tendência de São João e Apinagés parece ser estancar, se não retroceder. A Transamazônica constituiu-se no golpe de morte sobre a navegação fluvial, que já sofrera com a abertura da PA-70, e que dava vida, particularmente, ao porto de Apinagés. Mesmo que esse gênero de transporte eventualmente renasça jamais possuirá a posição dominante de outrora.

São Domingos sente-se abandonado pela prefeitura de São João do Araguaia $^{20}$, e a rivalidade entre os núcleos manifesta-se a todo instante ${ }^{21}$. Ao mesmo tempo, alguns comerciantes e fazendeiros do Sul (especialmente de Minas Gerais), em geral de posses médias semelhantes aos mais abastados de São Domingos, vão se interessando em estabelecer-se na área, comprando terras e abrindo comércio ${ }^{22}$.

${ }^{20}$ As necessidades de uma manobra política em nível estadual fizeram com que fossem obrigados a aceitar como candidato único a prefeito nas eleições passadas (as terceiras) um velho político de São João. A principal reclamação prende-se à não-conservação da estrada que liga São Domingos à Transamazônica (trecho da antiga estrada para Apinagés).

${ }^{21}$ Sabedores de que um grupo de freiras pretendia estabelecer-se no município, organizou-se em São Domingos uma arrecadação por ocasião da festa do padroeiro (4 de agosto de 1971), através de leilão de bezerros doados pelos pecuaristas locais e venda de votos num concurso de beleza, que atingiu Cr\$12.000,00. Construiu-se, então, em tempo recorde, uma casa para as freiras - a melhor do lugar - garantindo-se dessa maneira que não se fixassem em São João ou Apinagés.

${ }^{22}$ Interessante assinalar como a Amazônia é hoje vista por uma pequena burguesia do Sul ameaçada pela oligopolização das atividades de produção e comércio como uma espécie de refúgio. Eis o que diz um entrevistado vindo de Minas Gerais:

Está muito difícil para o comércio no Sul. Não tem mais pobreza lá para comprar, cada fazenda só tem dois, três peões. O pessoal de mais dinheiro 
Com isso surge em São Domingos do Araguaia, liderado pelos comerciantes locais e camponeses remediados, um movimento no sentido de transferir a sede do município para São Domingos; ou, então, para criarse um novo município. Assim, a frente agrícola inicia a contestação aberta à dominância da beira (ver cap. 7).

São Domingos atualmente não é nem sequer distrito (faz parte do de Apinagés). A estratégia inicial consiste em conseguir para São Domingos o controle do diretório da ARENA, atraindo elementos importantes de Apinagés (que vai tendendo a entrar na órbita de polarização de São Domingos), a fim de que o candidato a prefeito nas próximas eleições seja de São Domingos ${ }^{23}$. Os líderes locais discutem entre si, confidencialmente, qual deles será o candidato. Os principais atributos exigidos são a capacidade financeira ${ }^{24}$ e de congregar consigo sem maiores animosidades os demais membros da elite, bem como o eleitorado.

Num estudo de mudança, e num momento tão crucial, é curioso verificar, nesse nosso último lance de olhos sobre São Domingos do Araguaia, a permanência. São Domingos repete hoje luta análoga à que levou, mais de meio século atrás, à criação do município de Marabá. Restará saber até que ponto ainda existe lugar para a sua pequena elite integrar-se aos setores dominantes em escala supralocal.

compra fora e nas grandes lojas. Além disso, dentro de Governador Valadares a fiscalização é muito grande e só se pode ter $2,3 \%$ de lucro, levando anos assim. Aqui pode-se lucrar muito mais e em pouco tempo enricar.

${ }^{23}$ Não existe um diretório do MDB organizado no município, e aparentemente não se pensa na sua fundação como uma alternativa política. Todas as disputas se dão dentro da ARENA, que abriga todas as antigas facções, hoje em processo de realinhamento em face principalmente dessa nova questão.

${ }^{24}$ Certamente para financiar os gastos da campanha (inclusive doações ao eleitorado) e porque sendo do seio da elite os interesses fundamentais são os mesmos. Mas apresentam para isso uma justificativa classicamente liberal: a de que as pessoas bem sucedidas economicamente devem ter a liderança política porque já demonstraram nos seus negócios particulares a sua capacidade administrativa. Essa visão só pode se manter por ser possível ainda na região verificar-se de alguma maneira uma relação entre a ascensão econômica e o esforço pessoal.

\section{CONCLUSÕES}

Vimos nos primeiros capítulos deste trabalho como por muito tempo a região em estudo sofreu a influência indireta de várias frentes de expansão, sem no entanto chegar a ser incorporada à esteira de nenhuma delas.

É com a extração vegetal - primeiramente da borracha e depois da castanha - que ela efetivamente ganha uma história. É importante fixar, nesse processo, as solicitações externas e suas vicissitudes, bem como a maneira pela qual se dá a acumulação necessária e se organiza a produção. Quanto a este último ponto, deve-se ressaltar a formação de uma camada comercial dirigente e o seu papel, bem como o processo de concentração posterior.

A economia da extração vegetal tendia a desenvolver-se com nítido caráter exclusivista. Nos seus interstícios, todavia, inclusive pelo tipo de ocupação que engendrava, mantinha aberta a possibilidade de surgimento, marginalmente, de outras formas de produção.

Uma vez se apresentando novas condições no sistema envolvente que levam' a uma quebra do isolamento relativo da região, isso virá abalar o caráter exclusivista da economia localmente dominante.

Nesse processo, o que nos interessa basicamente é a mudança de caráter da pequena agricultura. Enquanto atividade intersticial aproximavase bastante da modalidade usual da pequena lavoura brasileira tradicional, que não chegava a permitir a constituição de um campesinato sólido incompatível com o domínio da plantation (ver TEPICHT) - e para cujo representante típico OBERG reservou a expressão "camponês marginal".

Em boa parte dos casos, o "camponês marginal" brasileiro constituiase numa reserva de mão-de-obra para a grande exploração segundo um mecanismo de fluxo e refluxo em relação ao mercado responsável pela estabilidade' relativa do sistema (ver FURTADO). Todavia, isso se dava de modo diferenciado e, nos casos extremos, o papel de reserva de mão-deobra tornava-se cada vez mais apenas uma possibilidade, realizável ou não conforme as vicissitudes da economia. 
A partir, aproximadamente, de meados do século XIX, a plantation nordestina, bem como seus subsistemas no agreste e no sertão (ver CUPERTINO e PALMEIRA), vão se mostrando incapazes de absorver amplamente os contingentes populacionais gerados nela mesma. Em momentos de dificuldades climáticas, o problema, de crônico, torna-se agudo.

A primeira grande alternativa, juntamente com a migração para as cidades, será o movimento em direção à Amazônia, na época da borracha, onde se estrutura uma organização da produção que lembra, ainda, sob certos aspectos, a plantation.

A queda da borracha coincidirá, aproximadamente, com o início do movimento migratório de caráter agrícola em direção aos vales úmidos do Maranhão. Trata-se, de certa forma, de uma tentativa de escapar do sistema. Nesse sentido, seria marginal ao extremo, já que mesmo enquanto reserva de mão-de-obra estes indivíduos não teriam mais lugar. Todavia, é exatamente essa marginalidade extremada, em face de novas condições que vão surgindo, que permite, de certo modo, vislumbrar-se uma nova posição. Isso porque, aos poucos, a marginal idade em relação à plantation deixa de identificar-se com uma marginalização em relação à formação social como um todo, dado, particularmente, o crescimento do mercado interno.

Isso cria um fato novo, que não parece enquadrar-se facilmente em nenhuma das duas vertentes principais em que se tem dividido o pensamento dos estudiosos sobre o desempenho da agricultura brasileira contemporânea. Durante bastante tempo prevaleceu uma visão pessimista em relação a esse desempenho, acreditando-se que a tendência seria a um agravamento cada vez maior. Essa visão era compartilhada por autores de tendências as mais diversas, que se mostravam, grosso modo, de acordo quanto à irracionalidade da exploração agrícola no Brasil, à sua excessiva dependência do mercado externo em detrimento do atendimento das necessidades internas, à existência de uma ampla massa de lavradores miseráveis excluídos da vida econômica nacional - o que inclusive comprometia o desenvolvimento da indústria pela escassez de mercados etc.

Nos últimos anos, graças em boa parte ao razoável desempenho da economia brasileira como um todo em termos de crescimento, surgiu uma nova corrente, que também passa por cima das divisões, inclusive ideológicas, e que defende ponto de vista contrário. Segundo esses autores, a agricultura brasileira tem de fato cumprido satisfatoriamente no fundamental suas funções. Demonstraria, no conjunto, razoável capacidade empresarial e de se modernizar, destacando-se o papel das grandes unidades de produção. Prova disso seria o abastecimento sem maiores crises dos centros urbanos nos últimos anos. Além do mais, o tipo de industrialização que se vem desenvolvendo entre nós é "precocemente" sofisticado, e vai apoiar-se no consumo dos grupos de rendas altas e médias, e na exportação, sem maiores necessidades de buscar um mercado de grandes massas no interior do país.

Um dos poucos pontos substantivos em torno do qual haveria certo acordo entre as duas correntes seria exatamente quanto à impossibilidade, $\mathrm{e}$ para a segunda corrente também a desnecessidade, de prosseguir o aumento da produção agrícola pela ocupação em larga escala de novas terras, devido inclusive aos custos relativos crescentes em face das distâncias cada vez maiores dos mercados consumidores.

Obviamente, o estudo que realizamos não serve para confirmar ou infirmar definitivamente nenhuma das teses, que se referem ao sistema nacional como um todo. Pode, porém, oferecer certos indícios, e mesmo certas informações, já que se trata de região estrategicamente colocada do ponto de vista dessa discussão, ainda pouco estudada e com grande riqueza de situações. Isso permite a formulação pelo menos de hipóteses a serem testadas.

De fato, em face disso a primeira visão aparenta ser um tanto abstrata e simplificadora. A segunda, efetivamente mais moderna e flexível, no entanto não deixa de realizar suas simplificações, seja por vezes dando como um fato presente aquilo que deve ser vislumbrado como uma tendência, seja, pelo contrário, não levando em conta os desdobramentos e transformações possíveis; em ambos os casos, procedendo de modo um tanto linear.

O exame da frente agrícola maranhense-paraense parece revelar, de imediato, dois fatos que, tomados em conjunto, não se ajustam a nenhuma das duas visões. Por um lado, temos que se trata de uma agricultura extensiva, de baixo nível tecnológico, apoiada basicamente na utilização de terra e mão-de-obra, em pequenas unidades produtivas, e que, no entanto, 
por outro lado, ganha importância considerável no suprimento do mercado interno, o que é atestado pela posição do Maranhão como produtor de arroz.

Teríamos, assim, um caso de pronta capacidade de resposta às solicitações do mercado - uma vez fornecidas as condições infra-estruturais indispensáveis para a comercialização - que se dá através de uma pequena produção mercantil, onde o homem continua a trabalhar mesmo quando a sua produtividade marginal é inferior ao seu custo de subsistência (ver CASTRO, p. 178). É a "barbárie do supertrabalho", de que fala KAUTSKY (p. 324). Mas é exatamente isto que aumenta a capacidade de resistência às condições adversas; o que parece atestar a eficácia, ainda, do mecanismo clássico da oscilação entre agricultura de subsistência e agricultura de mercado, porém agora no seio de uma economia transformada e fora do âmbito da grande propriedade ${ }^{1}$.

Possui, sem dúvida, como já frisamos nos capítulos anteriores, uma função em boa parte supletiva no mercado; mas no entanto indispensável. Em relação a essa função, a unificação do mercado nacional e a melhoria nos processos de comercialização, aceleradas nos últimos anos, foi favorável, exigindo, inclusive, uma qualificação dos argumentos sobre os custos de transporte ${ }^{2}$. Estaríamos, de fato, diante de uma espécie de arcaico modernizado, cujas características básicas, aliás, não podem ser impunemente violentadas. $\mathrm{Na}$ região em estudo, o afastamento excessivo dos limites onde funciona o esquema subsistência-mercado leva a uma aceleração à passagem à pecuária e/ou ao puro fracasso, e nesse sentido,

${ }^{1} \mathrm{O}$ que não exclui que mecanismo semelhante seja ativado em frentes de expansão em áreas renovadas, e mesmo em áreas efetivamente velhas. Porém, especialmente nesse último caso, provavelmente com menor dinamismo e em menor escala, e voltado preferencialmente para mercados locais que vão surgindo; embora, talvez com importância mais próxima no próprio rompimento do sistema da plantation (conforme sugestão de PALMEIRA). Não seria, então, somente manifestação do processo; apesar de possivelmente constituir-se em apenas um elemento no conjunto deflagrador. Tem-se, para o Brasil como um todo, que em 1960 2.284.836 dos 3.337.769 estabelecimentos agropecuários existentes ocupavam menos de 5 pessoas, o que dava um total de 5.575.286 indivíduos para uma população economicamente ativa de 15.633.985. Mesmo admitindo que a maior parte desses pequenos estabelecimentos se mantivesse quase que constantemente na mera marginalidade, é de se imaginar que algo poderia vir a ser produzido numa certa porção deles como excedente uma vez surgidas solicitações adequadas do mercado; embora, possivelmente, em boa parte dos casos apenas para consumo local.

Ver AVERBUG. mesmo o crédito bancário, quando mal dosado ou administrado, pode ser contraproducente.

Uma maneira de interpretar o caráter desta pequena agricultura de terras novas seria perceber o seu papel como sendo não só supletivo, mas também provisório, à medida que se ligue à passagem da agricultura dominada pela plantation, da qual ela é o fruto, direto ou indireto, mas também a negação, para uma agricultura tipicamente capitalista e em grande escala. $\mathrm{O}$ sistema da plantation, em seu auge, de fato tende a impedir o desenvolvimento de uma estrutura camponesa forte ${ }^{3}$. Surge apenas sob o seu domínio um ralo campesinato marginal ou uma pecuária involuida, lá onde ela decai, onde não chegou a alcançar ou nos buracos que deixa; e que absorve a parte do excedente demo gráfico que nunca deixou de existir e que não se dirigia para o setor terciário das cidades. Porém a sua desintegração é contemporânea e facilita o realce do papel da pequena produção mercantil; o que não significa que estes produtores sejam necessariamente oriundos da própria plantation, mas que de alguma maneira se ligavam ao sistema por ela dominado. Os momentos de maior procura, agora, de fato aproximam-nos do mercado; mas não por um retorno à produção comercial dentro do sistema da grande exploração tradicional, da qual seriam mera reserva de mão-de-obra ${ }^{4}$, e sim ainda enquanto pequenos produtores independentes voltados para o mercado interno.

Tudo isto, porém, neste caso dar-se-ia apenas nos quadros de uma transição ${ }^{5}$. Em outras faixas do território nacional, aliás, especialmente em áreas seminovas ou renovadas, como no próprio Brasil Central - no CentroSul de Goiás - não só a pecuária, mas particularmente a agricultura vai-se modernizando e se intensificando (numa espécie de equivalente funcional

${ }^{3}$ Mesmo na região estudada, é ilustrativo disso o fracasso do Burgo Agrícola do Itacaiúnas e de outras experiências realizadas na mesma época no Pará (ver cap. 3), em face de uma extração vegetal que na Amazônia tinha muitas semelhanças sob certos aspectos com a plantation.

${ }^{4}$ Tal como no caso da pecuária variava o grau de ligação com a grande exploração, o mesmo ocorria com esses lavradores, distinguindo-se aquele que era absorvido nos momentos de procura alta, o qual, nos casos mais próximos e típicos da plantation, já estaria situado dentro de seus domínios físicos, daquele que, ainda então, normalmente mantinha-se periférico. ${ }^{5}$ Os autores que mais parecem aproximar-se dessa visão, a despeito das diferenças de abordagem, são PAIVA e SINGER. 
da pecuária intensiva que hoje penetra no Pará); com a adubação, a mecanização e a possibilidade de utilização de terras de baixíssima produtividade natural. No conjunto, sem que se tenha uma estrutura agrária amplamente realizada de um ponto de vista capitalista, encontra-se o que passa por serem expedientes, e que funcionam relativamente a contento.

Todavia, existem obstáculos ao avanço da modernização, devido à escassez de capital, os custos ainda altos dos insumos agrícolas modernos, a instabilidade do mercado devido especialmente às deficiências ainda existentes na estrutura de comercialização e a entrada de novos produtores no mercado, a pequena absorção da mão-de-obra expulsa do campo na indústria moderna e a propensão marginal relativamente baixa a consumir alimentos, criando riscos de superprodução (já que a urbanização, por si, não cria novos consumidores, apenas alterando em certa medida a estrutura de gastos e necessidades) (ver PAIVA). O aumento da produção nos últimos anos tem levado à busca de mercados externos para os produtos alimentares - o que é coerente com os objetivos gerais da política econômica - reservando-se exatamente os setores mais modernizados para a exportação. É o que vem ocorrendo com o arroz gaúcho e, possivelmente, irá ocorrer com a crescente pecuária paraense. Esta é favorecida pela posição privilegiada do porto de Belém, já tendo sido realizados embarques de certo vulto para Caiena, que se inscrevem na meta de transformar a carne numa importante fonte de divisas para o país ${ }^{6}$. Ao contrário da carne, no entanto, o caminho que a rizicultura maranhense-paraense teria de percorrer para ganhar face semelhante seria muito longo e pouco provável; especialmente levando em conta que já há quem preencha o papel e que as possibilidades do mercado externo não são ilimitadas.

Em termos estritamente econômicos, portanto, é possível imaginar que o papel dessa pequena produção mercantil seja por um lado oscilante ${ }^{7}$

\footnotetext{
${ }^{6}$ Ver Correio da Manhã, 18/2/70
}

${ }^{7}$ Quanto ao seu caráter oscilante, é como se fosse um substituto da exploração dos "terrenos inferiores" (no que diz respeito à situação em relação ao mercado e/ou à fertilidade) por parte dos próprios capitalistas em condições de insuficiência de oferta, de que trata MARX ao analisar a renda fundiária. Interessante lembrar que KAUTSKY fala de um outro gênero de oscilação que envolveria pequenos e grandes produtores na Europa, em face da natureza de suas relações - ao mesmo tempo contraditórias e complementares - e que seria o movimento alternado da própria propriedade territorial entre concentração e subdivisão; o qual, também, só se resolveria em face das transformações gerais da sociedade. e, no longo prazo, declinante. Como no entanto, mesmo assim, em economia o curto e o médio prazos são seguidamente decisivos, particularmente em fases de arrancada, não se pode subestimar a importância desse gênero de agricultura, que se apóia quase que exclusivamente na utilização de terra e mão-de-obra, e que pode contribuir para evitar a necessidade pouco viável de não se utilizar uma tecnologia de alto nível na indústria por receio da não absorção de mão-de-obra em grande quantidade (ver SINGER).

No que diz respeito à caracterização desse novo tipo de camponês que surge, poder-se-ia dizer que de fato está próximo à marginalidade; porém, agora, ao contrário do caboclo ou do caipira examinados, entre outros, por CÂNDIDO e OBERG, e que NEIVA disse situar-se entre a fronteira demográfica e a fronteira econômica, oscilaria entre a marginalidade e a submarginalidade de um modo dificilmente classificável nos termos da dicotomia de WAIBEL de pioneiro e não-pioneiro ${ }^{8}$.

Na região do Itacaiúnas, a passagem da marginalidade à situação de oscilação se dará aproximadamente em 1964, quando se supera a fase dos excedentes eventuais da agricultura de beira-rio, ou mesmo da terra firme, que atendiam somente a um pequeno mercado regional. Para a região, podese dizer que em termos puramente econômicos e ideais esta fase de transição duraria até que o campesinato que restasse como tal retomasse a marginalidade, o grosso da frente prosseguindo para adiante. Neste sentido, a região do Itacaiúnas estaria sendo um laboratório onde se engendrariam as soluções capitalistas para a conquista por etapas da Amazônia: agricultura marginal de subsistência, estradas, pequena produção agrícola mercantil, pecuária intensiva e grande exploração mineral; quando possível partindo de uma produção extrativa tradidonal ou nova que auxiliasse uma acumulação local.

${ }^{8}$ Para WAIBEL (p. 391): “... Somente em poucos trechos de toda esta imensa área se desenvolveram zonas pioneiras. O conceito de pioneiro, para mim, significa mais do que o conceito de 'frontiersman', isto é, do indivíduo que vive numa fronteira espacial. O pioneiro procura não só expandir o povoamento espacialmente, mas também intensificá-lo e criar novos e mais elevados padrões de vida. Sim, empregamos o conceito de pioneiro também para indicar a introdução de melhoramentos no campo da técnica e mesmo da vida espiritual!'. 
$\mathrm{Na}$ região estudada, as tendências observáveis parecem contraditórias, já que existem forças agindo no sentido de expropriar os pequenos agricultores, ao mesmo tempo em que certos desenvolvimentos, como as estradas e algumas vantagens relativas que possuem, agem no sentido de fortalecê-los. De qualquer maneira, embora o avanço da frente seja hoje relativamente rápido, trata-se de um movimento de características quase seculares nos seus desdobramentos. No próprio Maranhão ainda existem terras por explorar, como no Gurupi, e que se abrem decisivamente com as construções de estradas que se vêm realizando. Entre estas contamse a Pará-Maranhão, que liga Belém a São Luís, e a que se dirige de São Luís para a Belém-Brasília, alcançando-a na altura de Açailândia, ao norte de Imperatriz, com que se busca reafirmar a unidade estadual ${ }^{9}$.

Em relação ao Nordeste, esse movimento todo pode representar um esvaziamento relativo. Já entre 1940 e 1950 os dados para o país como um todo indicam que quase dobrara o número dos estabelecimentos de posseiros e a área ocupada por eles. As áreas novas já eram da maior importância neste movimento, nelas sobressaindo a presença nordestina. Entre 1950 e 1960 o fenômeno prosseguiu.

QUADRO XIII

\begin{tabular}{ccc}
\hline Ano & Ocupantes \\
\hline 1920 & - & sem informação \\
1940 & - & 109.016 estabelecimentos \\
1950 & - & 208.657 estabelecimentos \\
1960 & - & 356.502 estabelecimentos \\
\hline
\end{tabular}

O Governo Federal, a partir da instalação do terceiro governo pós-64, começa a tomar consciência das possibilidades de aproveitar em grande escala a oportunidade do movimento nas áreas novas que se está ampliando. A fase de grande entusiasmo com as possibilidades de industrialização do

${ }^{9}$ A abertura da Transamazônica teve o efeito contraditório de tornar de certa maneira menos crucial a construção de certas estradas que já estava se dando através dos governos estaduais, como a que ligará São Luís à Belém-Brasília e a BEL-CAN, prolongamento da PA-70 na direção do Xingu (São Félix) e do Tapajós (Jacareacanga). com um ramal para Conceição do Araguaia. A construção de ambas as estradas prosseguiu, embora em ritmo lento durante certo tempo.
Nordeste, hoje um tanto reduzido, parece seguir-se à percepção do efeito multiplicador maior dos investimentos que se oferecem nas terras novas, especialmente no Centro-Norte, mesmo isso não significando uma nova opção unilateral que a complexidade da economia brasileira não mais comporta.

A própria convicção, porém, que atravessa o espectro político, de que o desenvolvimento do Brasil liga-se umbilicalmente ao desenvolvimento pleno do Nordeste, está por ser reexaminada. O desenvolvimento sem desequilíbrios não é da natureza do capitalismo, especialmente do gênero monopolista; embora esteja sempre exigindo reajustamentos gerais. A própria negação mais decisiva da velha plantation pode se desenrolar também num outro palco que não aquele em que ela dominou, no que é mais relevante para o sistema global. Se o movimento em direção às áreas novas tomar vulto, no entanto, ajudará a acelerar, sem dúvida, num efeito de feedback, as mudanças consideráveis que se vão dando no próprio Nordeste.

Todavia, tudo isto se correlacionará com as possibilidades de absorção de mão-de-obra e de expansão das frentes, o que dependerá do panorama geral do país e do gênero possível de desenvolvimento capitalista. Nesta corrida, irá se definindo não só o modo, mas também os limites das frentes de expansão contemporâneas e, simultaneamente, de toda a nossa sociedade tal como a conhecemos. Com a dominação de forças puramente econômicas, o destino da agricultura camponesa no Brasil é incerto, em face de dados que indicam tendências em conflito. Uma possibilidade, que mencionamos, é que venha a representar não mais do que uma transição para uma agricultura tipicamente capitalista. Há motivos, porém, para se crer que objetivamente o capitalismo brasileiro se caracteriza no que ele tem de mais fundamental por um modo de articulação entre o político e o econômico em que o político possui grande dominância, o que parece ser atestado pela própria construção da Transamazônica, cujo valor mera e imediatamente econômico é contestado por muitos especialistas (ver esp. CAMPOS).

Se isto se confirmar, bem como a impossibilidade de absorção total dos novos contingentes de mão-de-obra nos centros urbanos e industriais, mesmo a longo prazo; e se as políticas postas em execução, fugindo tanto a uma concepção de laissez-faire econômico quanto ao de uma onipotência 
estatal, encontrarem um equilíbrio entre a atividade do Estado e o livre desenvolvimento, então poderemos ter, não apenas uma transição ${ }^{10}$, mas a estabilização relativa de um setor camponês subordinado ao desenvolvimento capitalista principal, e um gênero de frente de expansão que fugirá ao padrão até agora usual no Brasil. Os próximos anos mostrarão o caminho que será seguido, e quais os desdobramentos possíveis ${ }^{11}$.

\footnotetext{
${ }^{10}$ Uma objeção metodológica e teórica ao tratamento da questão puramente em termos de transição estaria em que, mesmo ser do aceitável como caracterização, nem por isso se reduziria a um simples momento em fluxo, mas tratar-se-ia de uma época, com uma estrutura e uma permanência específicas. E uma vez que se determinasse essa estrutura, possivelmente ligada já a um modo em si específico de capitalismo, poderia alterar-se a resposta à questão: transição para o quê?

${ }_{11}$ Ver, a propósito, trabalho em elaboração a ser publicado em obra coletiva dos pesquisadores do Programa de Pós-Graduação em Antropologia Social do Departamento de Antropologia do Museu Nacional.
}

\section{BIBLIOGRAFIA}

ABREU, J. Capistrano de. Capítulos de História Colonial (1500-1800), $4^{\mathrm{a}}$ edição, Sociedade Capistrano de Abreu, Livraria Briguei, 1954.

ALMEIDA, Candido Mendes de. A Carolina ou a Definitiva Fixação de Limites entre as Províncias do Maranhão e de Goyaz, Rio, Typ. Episcopal de Agostinho de Freitas Guimarães Cia., 1852.

ANDRADE, Manuel Correia de. Paisagens e Problemas do Brasil, Ed. Brasiliense, $2^{\mathrm{a}}$ ed., 1969.

AUDRIN, José M. Entre Sertanejos e Índios do Norte: o bispo-missionário Dom Domingos Carrérot, O. P. Edições Pugil Ltda. Livraria Agir Editora, 1946.

AVERBUG, Marcelo. "Reflexos da estrutura agrária", em A Agricultura Subdesenvolvida, Coleção Caminhos Brasileiros, Ed. Vozes Ltda., Petrópolis, 1969.

BAENA, Antônio Ladislau Monteiro. Compêndio das Eras da Província do Pará, Universidade Federal do Pará, Coleção Amazônica, Série José Veríssimo (ed. original de 1838), 1969.

BAER, Werner. A Industrialização e o Desenvolvimento Econômico do Brasil, Fundação Getúlio Vargas, 1966.

BAPTISTA, Paulo Campos. "Brasileiros podem ter alimento na castanha", Correio da Manhã. 16/07/1967.

BETTELHEIM, Charles. A Transição para a Economia Socialista, Zahar Editores, Rio, 1969.

BUARQUE, Manoel. Tocantins e Araguaya, Belém, Typ. da Imprensa Official do Estado, 1919.

BUSCALIONE, Luigi. Una Escursione Botanica nell'Amazzonia, Società Geografica Italiana, Roma, 1901.

CAMPOS, Roberto de Oliveira. "La Rage de Vouloir Condure", Transamazônica, Ed. Brasiliense, 1970. 
CANDIDO, Antônio. Os Parceiros do Rio Bonito, Livraria José Olympio Editores, 1964.

CARDOSO, Clodoaldo. Municípios Maranhenses: Pastos Bons, Serviço Gráfico do Instituto Brasileiro de Geografia e Estatística, 1947.

CARDOSO DE OLIVEIRA, Roberto. O Processo de Assimilação dos Terêna, Museu Nacional, 1960.

. "Estudo de Áreas de Fricção Interétnica no Brasil", América Latina, Ano V, n. 3, 1960. 1964.

O Índio e o Mundo dos Brancos, Difusão Européia do Livro,

. “A Noção de 'Colonialismo Interno' na Etnologia”, Tempo Brasileiro, ano IV, n. 8, 1966.

. Problemas e hipóteses relativos à fricção interétnica: sugestões para uma metodologia”, Revista do Instituto de Ciências Sociais, Vol. 4, n. 1, 1967.

Urbanização e Tribalismo, Zahar Editores, Rio.

. A Sociologia do Brasil Indígena, Tempo Brasileiro, 1968.

CARVALHO, Carlota. O Sertão, Empresa Editora de Obras Scientificas e Literarias, Rio, 1924.

CASTRO, Antônio Barros de. 7 Ensaios sobre a Economia Brasileira $\left(1^{\circ}\right.$ vol.). Cia. Ed. Forense, 1969.

CIBRAZEM. Pesquisa Básica para um Programa Global ele Armaunagem Intermediária.

Comissão Diretora da Primeira Conferência Nacional da Castanha do Pará. Bases para uma política nacional da castanha (recomendações adotadas pela Conferência reunida em Belém em 1917).

CORREIO DA MANHÃ. "Governo investe no setor rural”. 18/02/1970.

"Pará", suplemento especial: VIII Caderno Norte-Nordeste, 26/02/1970
COUDREAU, Henri. Voyage au Tocantins-Araguaya; 31 décembre 189623 mai 1897, A. Lallure, Imprimeur-Editeur, Paris, 1897.

Voyage à Itaboca et à l'Itacayuna: ler juillet 1897-11 octobre 1897, A. Lahure, Imprimellr-Editeur, Paris, 1998.

CRUZ, Ernesto. Colonização do Pará, Instituto Nacional de Pesquisas da Amazônia, Belém, 1958.

CUPERTINO, Fausto. O Desenvolvimento do Modo de Produção de "Plantation" no Brasil (mn.)

DIAS, Catharina Vergolino. "Marabá - Centro Comercial da Castanha", Revista Brasileira de Geografia, n 4, Ano XX, out./dez., 1958.

"Aspectos geográficos do comércio da castanha no médio Tocantins", Revista Brasileira de Geografia, n 4, Ano XXI, out./dez, 1959.

"Amazônia Brasileira: Problemas de Subpovoamento", A Amazônia Brasileira em Foto, Comissão Nacional de Defesa e pelo Desenvolvimento da Amazônia, 1959.

ETEA (Equipe Técnica de Estatística Agropecuária - ex-SEP) Outubro de 1968 - Produtos Vegetais; 1967 (mim.)

FIBGE (Fundação IBGE). Anuário Estatístico do Brasil, 1969.

Sinopse Preliminar do Censo Demográfico; Brasil, 1917a.

. Sinopse Preliminar do Censo Demográfico; Pará, 1917b.

Anuário Estatístico do Brasil, 1917c.

FONSECA, Ribamar. "Pororoca ameaça a cidade à qual deu fama", Jornal do Brasil, 24/02/1970.

FURTADO, Celso. Formação Econômica do Brasil, Ed. Fundo de Cultura, $6^{\circ}$ ed., 1964.

GUIMARÃES, Alberto Passos. Quatro Séculos de Latifúndio, Ed. Fulgor Ltda, 1964.

GUNDER FRANK, André. Capitalism and Underdevelopment in Latin America. Monthly Review Press, Nova York e Londres, 1967. 
IBGE. Recenseamento geral do Brasil (1940), Série Nacional, Serviço Nacional de Recenseamento, 1950.

. Recenseamento Geral do Brasil (1940), Série Regional, Pará, Serviço Nacional de Recenseamento, 1952. 1956.

VI Recenseamento Geral do Brasil (1950), Série Regional, Pará,

. Enciclopédia dos Municípios Brasileiros, Vol. XIV, Amazonas, Pará, Territórios, 1957.

. Enciclopédia dos Municípios Brasileiros, Vol. XV, Maranhão e Piauí, 1959.

- Sinopse preliminar do censo demográfico, Estado do Pará (mim.), SNR, 1961a.

. Sinopse preliminar do censo demográfico; Estado do Maranhão (mim.), SNR, 1961b.

. Sinopse preliminar do censo demográfico; Brasil, SNR, 1962.

. VII Recenseamento Geral do Brasil, Sinopse preliminar do censo agrícola; Estado do Pará, SNR, 1963.

. VII Recenseamento Geral do Brasil, Sinopse preliminar do censo agrícola; Estado do Maranhão, SNR, 1964.

. Anuário Estatístico do Brasil, 1966.

. Esboço preliminar da divisão do Brasil nas chamadas "Regiões Homogêneas" (mim.) (2 vols.), 1967.

JORNAL DO BRASIL. "Estoque de arroz ameaça safra futura", 06/12/1969.

"Produção de trigo deste ano poderá aumentar 27\%", 04/01/1970.

. "Cirne Lima revê conceitos sobre reforma agrária", 09/01/1970.

. "Sem comprador o arroz do Rio Grande do Sul", 30/01/1970.

"Arroz tem esquema de escoamento", 13/02/1970.
"Juros baixam para crédito rural" (entrevista com o Ministro da Agricultura), 22 e 23/02/1970.

"Presidente anuncia rede de rodovias na Amazônia", 17/03/1970.

"DNER já projetou rodovia transamazônica", 18/03/1970.

KAUTSKY, Kart. A Questão Agrária, Ed. Laemmert, 1968.

LAGENEST, H. - D. Barruel de. Marabá, Cidade do Diamante e da Castanha, Ed. Anhembi, 1958.

LARAIA, Roque de Barros, e MATTA, Roberto Augusto da. Índios e Castanheiros, Difusão Européia do Livro, 1967.

MARQUES, César Augusto. Dicionário Histórico-Geográfico da Província do Maranhão, Patrocinada pela SUDEMA, Cia. Editora Fon-Fon e Seleta, Rio, $3^{\mathrm{a}}$ edição (1 ${ }^{\mathrm{a}}$ edição: 1870), 1970.

MARX, Karl. El Capital, libro tercero, sección sexta, caps. XXXIX e XL, Fondo de Cultura Económica, México, 1959.

MAYBURY-LEWIS, David. Estudo comparativo do desenvolvimento regional (mn.), 1969.

MELATTI, Julio Cezar. Índios e Criadores; a situação dos Krahó na área pastoril do Tocantins, monografias do Instituto de Ciências Sociais, 3, 1967.

MOREIRA NETO, Carlos A. A Cultura Pastoril do Pau d' Arco, Boletim do Museu Paraense Emilio Goeldi, INPA, CNPq, n 10 , março, 1960.

MOURA, Ignácio Batista de. De Belém a S. João do Araguaya; Valle do Rio Tocantins, H. Garnier Livreiro-Editor, Rio e Paris, 1910.

NEIVA, Arthur Hehl. "A imigração na política brasileira de povoamento", Revista Brasileira dos Municípios, ano 11, n.6, abril-junho, 1949.

OBERG, Kalervo. "The marginal peasant in rural Brazil", American Anthropologist, n. 6, Part I, December, 1965.

OLIVEIRA, Américo Leonidas Barbosa de. O Vale Tocantins-Araguaia; possibilidades econômicas, navegação fluvial, Imprensa Nacional, Rio, Ministério da Viação e Obras Públicas, 1941. 
PAIVA, Ruy Miller. "Reflexões sobre as tendências da produção, da produtividade e dos preços do setor agrícola do Brasil" e "Bases de uma política para a melhoria técnica da agricultura brasileira", $A$ Agricultura Subdesenvolvida, coleção Caminhos Brasileiros, Ed. Vozes Ltda., Petrópolis, 1969.

PALMEIRA, Moacir Gracindo. Latifundium et Capitalisme: lécture critique dun debat, Thèse de 3ème. Cycle presentée à la Faculté de Lettres et Sciences Humaines de l'Université de Paris (mn.), 1969.

PANDOLFO, Clara. Castanha do Pará e seu beneficiamento; estudo genérico, excerto do trabalho apresentado ao I Encontro de Investidores da Amazônia em dezembro de 1966.

PARÁ. O Pará em 1922, publicação oficial, Belém, 49, 1922.

PATERNOSTRO, Júlio. Viagem ao Tocantins, Companhia Editora Nacional, Coleção Brasiliana, S.P., 1945.

PENNA FRANCA e outros. "Radioatividade das castanhas do Pará", Atas do Simpósio sobre a Biota Amazônica, Vo1. 4 (Botânica), 1967.

PRADO JR., Caio. História Econômica do Brasil, Ed. Brasiliense, $7^{\mathrm{a}}$ ed., 1962.

QUEIROZ, Maria Isaura Pereira de. "Les classes sociales dans le Brésil actuel", Cahiers Internationaux de Socialogie, Vol. XXXIX, 1965.

RODRIGUES, Hildebrando (org.). Álbum do Pará, Belém, 1939.

RODRIGUES, Lysias A. O Rio dos Tocantins. IBGE, Conselho Nacional de Geografia, 1945.

SALLES, Vicente. O Negro no Pará, Fundação Getúlio VargasUniversidade Federal do Pará, Rio, 1971.

SANTA ROSA, Henrique. Álbum do Pará em 1899.

SEP (Serviço de Estatística da Produção). Fevereiro de 1964 - Produção extrativa vegetal; 1962 ( $\mathrm{mim}$.).

SERFHAU. Relatório preliminar de Desenvolvimento Integrado do Município de Marabá-PA.
SERVICE, Elman R. e Helen S. Tobati: Paraguaian Town, The University of Chicago Press, Chicago, III, 1954.

SERVIÇO DE INSPEÇÃO E FOMENTO AGRÍCOLA. A Exploração da Castanha no Pará. Rio, Ministério da Agricultura, Indústria e Comércio, 1929.

SINGER, Paul Israel. $O$ papel do crescimento populacional no desenvolvimento econômico, tese de livre-docêncla apresentada à Faculdade de Higiene e Saúde Pública da Universidade de São Paulo (mim.) (Publicado em 1970 por Edições CERRAP, S.P.), 1968.

SOARES, Lúcio de Castro. Amazônia, Guia da excursão n. 8, realizada por ocasião do XVIII Congresso Internacional de Geografia, Conselho Nacional de Geografia, Rio, 1963.

SODRÉ, Nelson Werneck. Formação Histórica do Brasil, Ed. Brasiliense.

SUDENE. Plano Diretor do Desenvolvimento do Nordeste (Segunda Etapa); 1963/1965 (mim.), Recife, outubro, 1969.

SUNAB. Conjuntura do Arroz, 1969.

TEPICHT, Jersy. "Les complexités de I'economie paysanne”, Information, dez.1969.

VEJA. A conquista do Oeste, n. 71, Ed. Abril, 14/01/1970.

VELHO, Otávio Guilherme. "Análise preliminar de uma frente de expansão da sociedade brasileira", Revista do Instituto de Ciências Sociais, Vol. 4, n. I, 1967.

"O conceito de camponês e sua aplicação à análise do meio rural brasileiro", América Latina, Ano 12, n. 1, 1969.

WAIBEI, Leo. "As zonas pioneiras do Brasil", Revista Brasileira de Geografia, ano XVII, n. 4, 1955.

WOLF, Eric R. "Types of Latin American peasantry: a preliminary discussion", American Anthropologist, 57, 1955. 

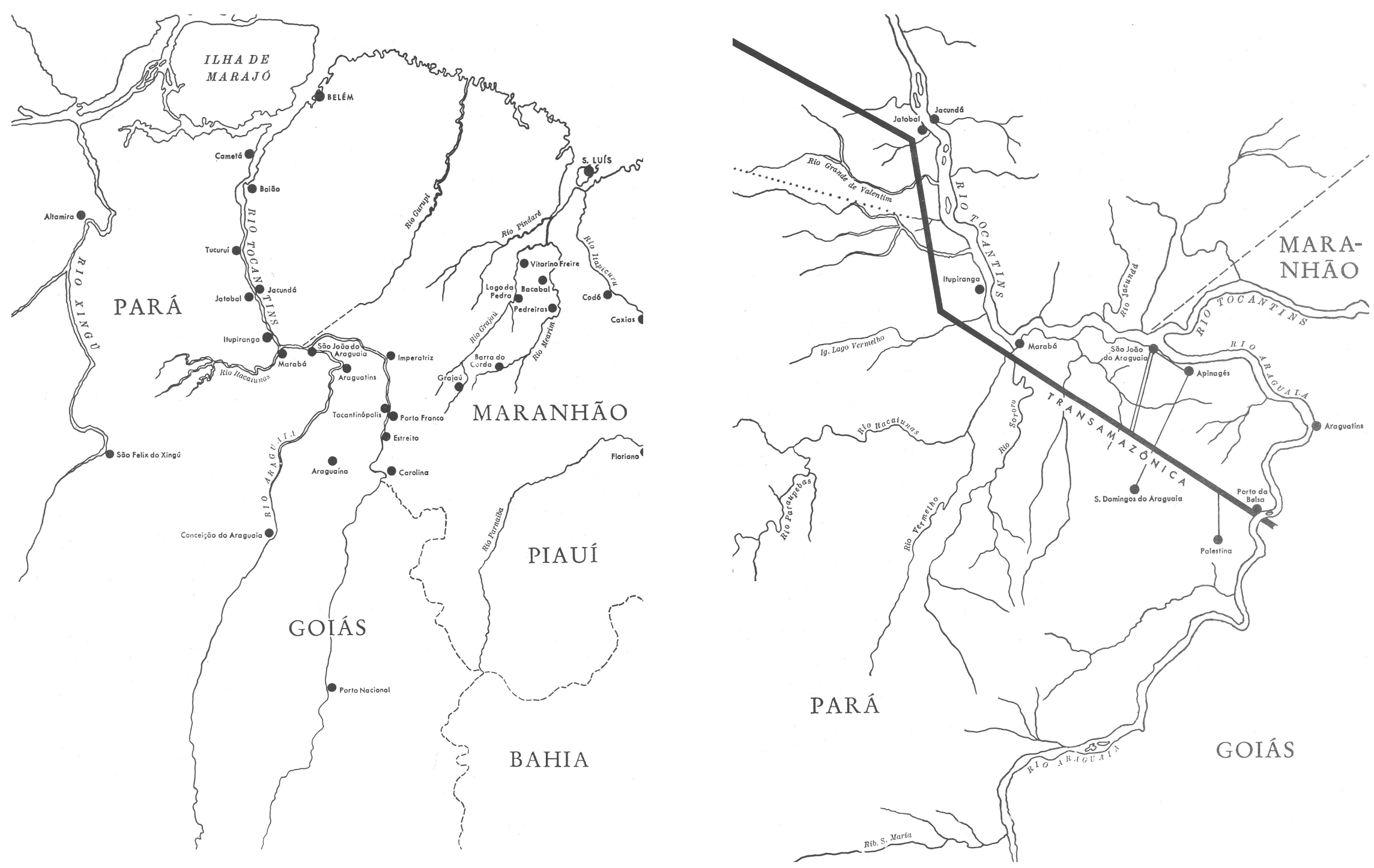

171

172 